\title{
Padrões para introduzir novas ideias na indústria de software
}

\section{Daniel Cukier}

\author{
DISSERTAÇÃO APRESENTADA \\ AO INSTITUTO DE MATEMÁTICA E ESTATÍSTICA \\ DA UNIVERSIDADE DE SÃO PAULO \\ PARA OBTENÇÃO DO GRAU DE MESTRE \\ EM CIÊNCIAS
}

Área de Concentração : Ciência da Computação

Orientador : Prof. Dr. Fabio Kon

São Paulo, 12 de abril de 2010 


\title{
Padrões para Introduzir Novas Ideias na Indústria de Software
}

\author{
Este exemplar corresponde à redação \\ final da dissertação devidamente corrigida \\ e defendida ${ }^{1}$ por Daniel Cukier \\ e aprovada pela Comissão Julgadora.
}

São Paulo, 12 de abril de 2010

Banca Examinadora :

Prof. Dr. Fabio Kon - IME-USP (Presidente)

Prof. Dr. Alfredo Goldman - IME-USP

Prof. Dr. Arlindo Flávio da Conceição - DCT-UNIFESP

${ }^{1} \mathrm{O}$ vídeo da apresentação da defesa pode ser visto no endereço http://vimeo.com/4766693 
aos meus pais Denise e Mayer, Mauro e Simone, aos meus irmãos Melissa, Diego e Mayara à minha amada Daniella 


\section{Agradecimentos}

Aos meus pais e irmãos, pela confiança, apoio e respeito. À minha esposa, Daniella Alcarpe, por todo incentivo e paciência. Aos meus amigos Marco Spivack e Maria Mizrahi, por participarem ativamente de todos os passos que fizeram parte desse processo. Ao meu amigo Eduardo Karpat, por sempre me dar várias sugestões pertinentes.

À Locaweb, por me oferecer o ambiente perfeito para meu trabalho e me incentivar nos meus estudos. Aos meus amigos da Locaweb, em especial a todo o time de Telecom pela confiança. Ao Gustavo Barrancos, por sempre mostrar interesse e me recomendar várias referências para esse trabalho. Ao Maurício De Diana, por todas as conversas de corredor, as sugestões e críticas. À Andreza Vasconcelos, pelo apoio em todas as minhas iniciativas.

Aos companheiros da AgilCoop, pelos palpites, pelas informações trocadas e todas as colaborações, que foram essenciais para a conclusão deste trabalho: Hugo Corbucci, Mariana Bravo, Paulo Cheque, Danilo Sato, Dairton Bassi, Alexandre Freire. Em especial ao Prof. Alfredo Goldman, por sempre mostrar interesse nos meus seminários e me incentivar a ir fundo nos estudos.

A todos os alunos e colegas que participaram das entrevistas e pesquisas.

À Profa. Jolanda Gentilezza, que com todo carinho me forneceu material vasto para poder realizar esse trabalho. Sem ela o teatro não faria parte da minha vida e este trabalho estaria incompleto. Ao Prof. Valdemar Setzer, por despertar nos alunos do IME-USP o interesse pela Arte. Agradeço muito ao Prof. Valdemar por todos os seus artigos e ideias, que serviram de base para esta dissertação.

Ao meu orientador, Prof. Fabio Kon, sempre muito atencioso e exigente, me fez trabalhar com diligência e perseverança. Também confiou muito em mim e me incentivou a abordar temas desafiadores.

Agradeço a todos que contribuíram, de forma direta ou indireta, para a conclusão desse trabalho. Todos os autores consultados e todas as pessoas, que de alguma forma conviveram comigo nesses anos de elaboração da dissertação, contribuíram para a sua realização. 


\section{Resumo}

A indústria de software é muito dinâmica e novas ideias surgem a todo instante em todas as partes do mundo. Nem sempre é fácil fazer com que essas ideias sejam adotadas, pois, para isso, é preciso fazer as pessoas mudarem sua forma de pensar. Deve-se sempre considerar o fato de que o ser humano, diferente do computador, é inusitado e imprevisível. Apesar disso, podemos encontrar determinados padrões de comportamento, que não resolvem todas as questões, mas ajudam a lidar com situações e continuar caminhando para atingir um determinado objetivo.

Trazemos nesta dissertação uma pequena introdução sobre o conceito de padrões e, em seguida, apresentamos 48 Padrões para Introduzir Novas Ideias, propostos por Linda Rising e Mary Lynn Manns. Esses Padrões têm o objetivo de ajudar na difícil tarefa de introduzir uma nova ideia dentro de alguma organização, pois se essa ideia pressupõe mudanças culturais, o trabalho é ainda mais complicado. Propomos também quatro novos padrões, que podem ser incorporados ao catálogo original.

Num desses novos padrões, mostramos a importância de se usar atividades artísticas no dia-a-dia de pessoas que trabalham com desenvolvimento de software; mostramos também como a Arte pode nos ajudar a introduzir novas ideias. Pesquisamos algumas práticas como teatro, pintura, poesia, música e meditação. Pudemos encontrar elementos de ligação entre o lado puramente matemático e bem definido do ser humano e o seu lado abstrato, analógico e artístico. Desenvolver software deve ser encarado como uma atividade humana, acima da questão técnica e puramente lógica. Existem pessoas envolvidas no processo: as que usam e as que criam o software. Existe uma barreira que separa os programadores das pessoas que usam o software. Essa barreira pode ser quebrada se pessoas da Computação começarem a desenvolver, além das habilidades lógicas que já lhes são óbvias, habilidades artísticas e de relações humanas. 


\section{Abstract}

The software industry is very dynamic and new ideas arise all the time from virtually any part of the world. It is not guaranteed that these ideas will be adopted, mainly because, among other obstacles, the solution may imply in having people change their way of thinking. Different from people, computers receive well defined commands and execute them precisely. We should take into account that human beings are independent and unpredictable. Despite of this unpredictability, we can find some behavioral patterns to help us deal with several situations, allowing us to achieve our objectives.

This work brings a small introduction into the pattern concept and a presentation of the 48 Patterns for Introducing New Ideas proposed by Linda Rising and Mary Lynn Manns. These patterns provide some insight into the difficult task of introducing new ideas into any organization. We show that if the idea brings cultural changes of any kind, then the task is even more complicated. We also propose four new patterns that can be added to the original catalog.

In one of these new patterns, we show the great importance of combining artistic activities with the day-to-day activities of people who work in software development and how Arts can help us to introduce new ideas. The study of some practices such as theater, painting, poetry, music and meditation allowed us to find some connective elements between the purely mathematical side of the human mind and its creative, artistic one. Software development must be approached as a "human activity", rather than a solely technical or logical one. Above all, there are two groups of people involved in the process: software creators and users. Although a barrier appears to separate these two groups, in this thesis we will show evidences that this division or gap can be bridged if IT professionals nurture their artistic and interpersonal relationship skills in addition to their obvious technical ones. 
"Um dia de chuva é tão belo como um dia de sol. Ambos existem, cada um como é." Fernando Pessoa 


\section{Sumário}

$\begin{array}{ll}\text { Prelúdio } & 14\end{array}$

1 Introdução $\quad 23$

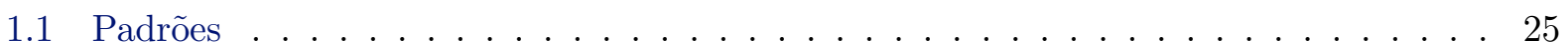

1.2 Arte e Trabalhos Relacionados . . . . . . . . . . . . . . . . . 27

2 Padrões para Introduzir Novas Ideias $\quad 31$

2.1 As Pessoas . . . . . . . . . . . . . . . . . . . . . . . 33

2.1 .1 Inovador (Innovator) . . . . . . . . . . . . . . . . 33

2.1.2 Os que Adotam Cedo (Early Adopter) . . . . . . . . . . . . . . . 33

2.1.3 Primeira Maioria (Early Majority) . . . . . . . . . . . . . . . . . 33

2.2 Por onde começar? . . . . . . . . . . . . . . . . . . 36

2.2 .1 Evangelista (Evangelist) . . . . . . . . . . . . . 36

2.2.2 Experimente a Água (Test the Waters) . . . . . . . . . . . . . . . 37

2.2.3 Tempo para Reflexão (Time for Reflection) . . . . . . . . . . . . . . . . 37

2.2.4 Pequenos Sucessos (Small Successes) . . . . . . . . . . . . . . . 37

2.2.5 Passo a Passo (Step by Step) . . . . . . . . . . . . . . . . . 38

2.3 O que Fazer em Seguida $\quad \ldots \ldots \ldots$. . . . . . . . . . . . . . 39

2.3.1 Conectores (Connector) . . . . . . . . . . . . . . 39

2.3.2 Guru ao Seu Lado (Guru on Your Side) . . . . . . . . . . . . . . . . . . . 39

2.3.3 Peça Ajuda (Ask for Help) . . . . . . . . . . . . . . . . . . . . . 41

2.3.4 Diga Obrigado (Just Say Thanks) . . . . . . . . . . . . . . . 41

2.4 Encontros e Reuniões . . . . . . . . . . . . . . . . . . . . . . . . . . . . . 41

2.4 .1 Adendo (Piggyback) . . . . . . . . . . . . . . . . . 42

2.4.2 Saco de Papel (Brown Bag) . . . . . . . . . . . . . . . . . . 42

2.4 .3 Inclua Comida (Do Food) . . . . . . . . . . . . . . . . . . . . . . 42

2.4.4 A Hora Certa (The Right Time) . . . . . . . . . . . . . . . . . . . 43 
2.4.5 Plante as Sementes (Plant The Seeds) . . . . . . . . . . . . . . . . . . 44

2.4.6 Validação Externa (External Validation) . . . . . . . . . . . . . . . . 44

2.4.7 Próximos Passos (Next Steps) _ . . . . . . . . . . . . . . . . . 45

2.4 .8 Manter Contato (Stay in Touch) . . . . . . . . . . . . . . . . . 45

2.4 .9 Fórum Eletrônico . . . . . . . . . . . . . . . . . . . . . . 46

2.4 .10 Identidade do Grupo (Group Identity) . . . . . . . . . . . . . . . . . 46

2.5 Em Ação . . . . . . . . . . . . . . . . . . . . . . . . . . . 46

2.5.1 Simplesmente Faça (Just Do It) . . . . . . . . . . . . . . . . 46

2.5.2 Mentor (Mentor) . . . . . . . . . . . . . . 47

2.5.3 Grupo de Estudos (Study Group) . . . . . . . . . . . . . . . . . 47

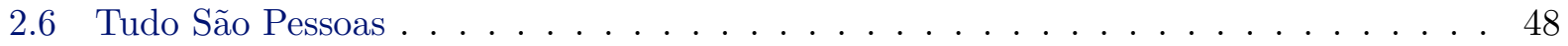

2.6.1 Toque Pessoal (Personal Touch) . . . . . . . . . . . . . . . 49

2.6.2 Terno de Alfaiate (Tailor Made) . . . . . . . . . . . . . . . . 49

2.6.3 Ombro para Chorar (Shoulder to Cry On) . . . . . . . . . . . . . . . 49

2.7 Um Novo Papel: Agora Você é Dedicado! . . . . . . . . . . . . . . . . . . . . 50

2.7.1 Defensor Dedicado (Dedicated Champion) . . . . . . . . . . . 50

2.7.2 Patrocinador Local (Local Sponsor) _ . . . . . . . . . . . . . . . . 50

2.7.3 Anjo Corporativo (Corporate Angel) . . . . . . . . . . . . . . . 51

2.8 Convencendo as Massas . . . . . . . . . . . . . . . . . . . . . 51

2.8 .1 Rodada de Testes . . . . . . . . . . . . . . . . . . . . . . . 51

2.8.2 Revisão do Guru (Guru Review) ～. . . . . . . . . . . . . . . . . . . . 52

2.8.3 Grande Personalidade (Big Jolt) . . . . . . . . . . . . . . . . 52

2.8.4 Audiência Real (Royal Audience) . . . . . . . . . . . . . . . . . 54

2.9 Estratégias para Influenciar . . . . . . . . . . . . . . . . . . 54

2.9.1 Histórias para Contar (Hometown Story) . . . . . . . . . . . . . . . . 54

2.9.2 O Cheiro do Sucesso (Smell of Success) . . . . . . . . . . . . . . . . . . . . . . . . . 55

2.9.3 O Suficiente (Just Enough) _ . . . . . . . . . . . . . . . . . . 55

2.9.4 No Seu Espaço (In Your Space) . . . . . . . . . . . . . . . . . . 56

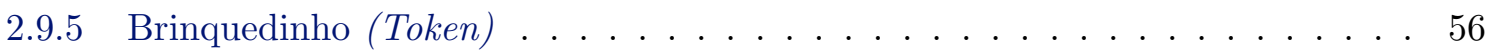

2.9.6 Local, Local, Local (Location, Location, Location) . . . . . . . . . . . . . 58

2.10 Continue Caminhando . . . . . . . . . . . . . . . . . . . . 58

2.10 .1 Envolva Todos (Involve Everyone) . . . . . . . . . . . . . . 58

2.10 .2 Momento Sustentável (Sustained Momentum) . . . . . . . . . . . . . . 59

2.11 Lidando com Resistência . . . . . . . . . . . . . . . . . . . . . . . . . 59

2.11 .1 Construtor de Pontes (Bridge-Builder) . . . . . . . . . . . . 60 
2.11 .2 O Cético Defensor (Champion Skeptic) . . . . . . . . . . . . . . . 60

2.11.3 Política de Corredor (Corridor Politics) . . . . . . . . . . . . . . . . 60

2.11 .4 Sem Medo (Fear Less) . . . . . . . . . . . . . . . . . . . . . . . 61

2.11.5 Sussurre no Ouvido do General (Whisper in the General's Ear) . . . . . . . . 61

2.12 Resumo dos Padrões para Introduzir Novas Ideias . . . . . . . . . . . . . . . . . 62

2.13 Limitações da Abordagem . . . . . . . . . . . . . . . . . . . . . . 67

3 Sugestões de Novos Padrões $\quad 69$

3.1 Brinque com Eles (Let Them Play) . . . . . . . . . . . . . . . . . . . 69

3.2 Mergulhe Fundo . . . . . . . . . . . . . . . . . . . . . 70

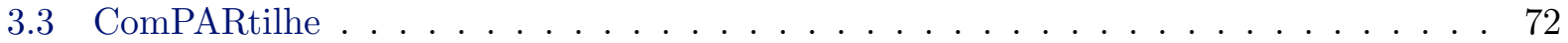

3.4 Faça Arte . . . . . . . . . . . . . . . . . . . . . 73

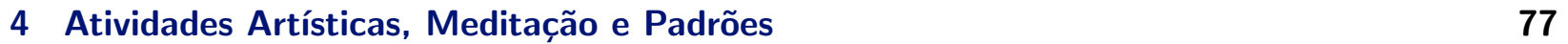

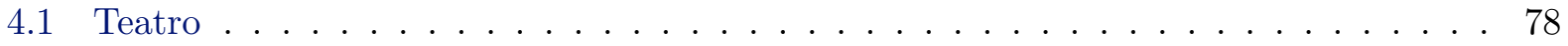

4.1 Dojo e Teatro Fórum . . . . . . . . . . . . . . 83

4.1.2 Depoimentos dos alunos de leitura dramática no IME-USP . . . . . . . . . . 86

4.1 .3 Entrevistas . . . . . . . . . . . . . . . . . . 88

4.1 .4 Pesquisa . . . . . . . . . . . . . . . . . . . . 92

4.1.5 Proposta de aprendizado técnico usando dramaturgia . . . . . . . . . . . . . 99

4.1.6 O Teatro e Padrões para Introduzir Novas Ideias . . . . . . . . . . . . . . . 108

4.2 Música . . . . . . . . . . . . . . . . . . . . . . . . . 108

4.3 Desenho e Pintura . . . . . . . . . . . . . . . . . . . . . . . . 109

4.3 .1 Beleza no código . . . . . . . . . . . . . . . . . . . . 112

4.3.2 Refatoração em Desenho . . . . . . . . . . . . . . . . . . . 113

4.3.3 Desenho, Pintura e Padrões para Introduzir Novas Ideias . . . . . . . . . . 115

4.4 Poesia . . . . . . . . . . . . . . . . . . . . . . 116

4.4.1 Poesia e Padrões para Introduzir Novas Ideias . . . . . . . . . . . . . . . . . 122

4.5 Meditação . . . . . . . . . . . . . . . . . . . . . . . . 123

4.5 .1 Vipassana . . . . . . . . . . . . . . . . . . . . . 124

4.5.2 Meditação Transcedental . . . . . . . . . . . . . . . . . . . 126

4.5.3 Meditação e Padrões para Introduzir Novas Ideias . . . . . . . . . . . . . . 126

4.5.4 Meditação, XP e Mudanças sem Medo . . . . . . . . . . . . . . . . . . . 127

4.6 Pesquisa de interesses artísticos . . . . . . . . . . . . . . . . . . . . 129

4.6.1 Pesquisa com colaboradores de uma empresa de tecnologia . . . . . . . . . 129

4.6.2 Pesquisa em um evento de Métodos Ágeis . . . . . . . . . . . . . . . . . . 130 
4.6 .3 O uso da Arte na Indústria de Software . . . . . . . . . . . . . . . . 133

5 Conclusões $\quad 135$

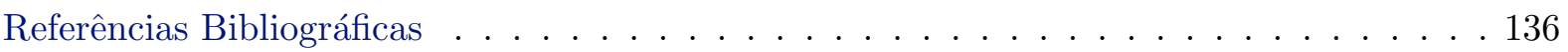




\section{Lista de Figuras}

1.1 Literatura sobre Padrões . . . . . . . . . . . . . . . . . . . 26

2.1 Estado inicial do processo da lavanderia . . . . . . . . . . . . . . . . 34

2.2 Aumentando a saída ao pendurar roupas para secar . . . . . . . . . . . . . 35

2.3 Modelo "pull" de desenvolvimento . . . . . . . . . . . . . . . . . . 35

2.4 Evento técnico: todos almoçando juntos, com a comida oferecida pela empresa . . . 42

2.5 Quadro de histórias utilizado por uma equipe ágil . . . . . . . . . . . . . . . 57

2.6 Área de trabalho informativa: dicas da metodologia . . . . . . . . . . . . . . 57

2.7 Habilidades individuais unidas num objetivo comum . . . . . . . . . . . 58

2.8 Ponte: o velho ligado ao novo . . . . . . . . . . . . . . . . . . . . 60

2.9 Mapa mental dos Padrões para Introduzir Novas Ideias . . . . . . . . . . . . . . . 63

3.1 Esquema: Trabalho $\mathrm{x}$ Estudo $\mathrm{x}$ Jogo . . . . . . . . . . . . . . . . . 70

4.1 Encenação da peça "As Eruditas" por alunos de Ciência da Computação no IME-USP 84

4.2 Satisfação dos alunos de Computação de terem cursado Leitura Dramática . . . . . . 95

4.3 Mudanças que o curso trouxe para a vida dos alunos . . . . . . . . . . . . . . 96

4.4 Existe diferença entre um curso de teatro para Computação e um curso de teatro normal . . . . . . . . . . . . . . . . . . . . 97

4.5 Os alunos acham que Leitura Dramática deveria ser obrigatória? . . . . . . . . . . 97

4.6 A importância da Arte para um aluno de Computação . . . . . . . . . . . . . . . 98

4.7 O aluno recomendaria a disciplina para algum colega? . . . . . . . . . . . . . 98

4.8 Que atividades artísticas são praticadas pelos alunos? . . . . . . . . . . . . . . 99

4.9 Anos e anos de aperfeiçoamento de projeto . . . . . . . . . . . . . . . . . 112

4.10 Refatoração em Desenho . . . . . . . . . . . . . . . . . . . . . . . . . . . 114

4.11 Refinamento do texto através de refatorações: polimento da pedra . . . . . . . . . 119

4.12 Vipassana: Modelo Mental Simplificado . . . . . . . . . . . . . . . . . . . . 125

4.13 Pesquisa sobre interesses artísticos: legenda . . . . . . . . . . . . . 130 
4.14 Pesquisa sobre interesses artísticos: resultados . . . . . . . . . . . . . . . . 131 


\section{Lista de Tabelas}

2.1 Resumo dos Padrões para Introduzir Novas Ideias . . . . . . . . . . . . . . . . 67

4.1 Desenvolvimento vs. Produção $[\mathrm{PP} 03] \ldots \ldots \ldots \ldots$. . . . . . . . . 80

4.2 Dados da pesquisa de interesses artísticos . . . . . . . . . . . . . . 130

4.3 Pesquisa sobre a prática de atividades artísticos durante o Encontro Ágil 2008 . . . . 132

4.4 Pesquisa sobre interesse futuro em atividades artísticas durante o Encontro Ágil 2008132 
Lista de Tabelas 


\section{Prelúdio}

Um grande projeto não se faz de um grande passo, mas sim de vários pequenos passos ${ }^{2}$. Para trilhar um longo caminho é preciso que se dê o primeiro passo ${ }^{3}$. Muito bem, vamos caminhar. Passo número um: começar o texto (que já começou). Passo número dois: defender uma dissertação de mestrado. Passo três: fazer com que as ideias dessa dissertação se disseminem para que outros realizem novos trabalhos científicos e tecnológicos em benefício da humanidade.

Neste trabalho falamos de Padrões para Introduzir Novas Ideias. O texto está recheado de meta-linguagem: usamos esses padrões para ajudar na escrita do texto, que fala dos próprios padrões. Usamos Arte para falar de padrões e também usamos padrões para falar de Arte.

Uma ótima maneira de aprender a fazer alguma coisa é fazendo. Os livros de português e gramática estão aí e ajudam muito no ensino da escrita, mas para aprender a escrever é preciso escrever. Assim como para aprender a fazer software é preciso programar. Só se aprende a meditar meditando. São atividades cujo aprendizado vem principalmente da prática, não só da teoria.

Neste trabalho abordamos as práticas, não as teorias. Recomendamos a ação e a Arte. Arte é ação, é criação. Do dicionário [WeS98]:

cri.a.ção sf (lat creatione) 1 Ação ou efeito de criar, de tirar do nada. 2 Totalidade dos seres criados. 3 O universo visível. 4 Produção, obra, invento. 5 Estabelecimento, formação, fundação, instituição. 6 Amamentação de uma criança. 7 Educação. 8 Animais domésticos que se criam para alimento do homem. 9 Propagação da espécie. 10 Alvenaria de pedras miúdas e argamassa que serve de enchimento aos vãos deixados pelas pedras mais volumosas. 11 Nas agências de publicidade, o conjunto formado pelos departamentos de redação e de Arte.

Alguns significados da palavra criação são óbvios $(1,4,5)$. Observemos o significado 6: criar é como amamentar uma criança, dar alimento a algo que hoje é pequeno, mas que um dia poderá se tornar grandioso. Na definição 8, temos que a criação é um animal que alimentará o homem.

\footnotetext{
${ }^{2}$ Vide Seção 2.2.5.

${ }^{3}$ Vide Seção 2.5.1.
} 
É o homem quem cria e se alimenta de sua própria criação. A definição 10 é uma das mais surpreendentes. É uma definição puramente material. De todas as definições, é a que melhor pode ser imaginada. Quem não consegue imaginar facilmente um pedreiro preenchendo buracos da parede com argamassa? Essa parece uma imagem interessante: a criação não é o muro todo, mas pequenas partes que preenchem o todo, que completam as lacunas.

Este documento não ensina a construir muros (ideias), mas como tornar mais sólidos e concretos os muros (as ideias) que já existem. Todos nós temos grandes ideias, algumas delas maravilhosas e inovadoras. Mas poucos de nós conseguimos realizar, materializar essas ideias. As lições deste texto podem ajudar. Se não sabe por onde começar, comece por algum lugar. Gandhi disse: "Só os idiotas esperam a perfeição. O sábio procura o aprendizado". Então, o que fazer para aprender? Simplesmente Faça ${ }^{4}$.

As ideias deste texto são misturas. São as experiências reais do autor misturadas com ideias tiradas de livros, artigos, cinema, obras de Arte, teatro, música, enfim, todas as fontes que de alguma forma contribuíram para a realização deste documento.

Este trabalho de pesquisa buscou não só inovações no conteúdo mas também na forma como ele seria apresentado, fugindo do padrão das dissertações de mestrado em Ciência da Computação. Portanto, ressaltamos que este trabalho não seguirá formas convencionais de textos puramente científicos. Esse é um alerta para o leitor que está acostumado com um certo formalismo nos textos das ciências exatas. A linguagem usada em alguns pontos é propositadamente informal, prezando um caráter mais poético e artístico. Também as imagens escolhidas muitas vezes não têm uma ligação lógica direta e concreta com o texto. Tentamos trazer nas figuras sensações e sentimentos, mais do que pensamentos lógicos. Recomendamos ao leitor apreciar as imagens com atenção, imaginar-se nos lugares onde as fotografias foram tiradas e refletir sobre a sensação de fazer parte da imagem vista.

Neste trabalho falamos muito de pessoas. Se existe um grande trabalho realizado, existem pessoas por trás desse trabalho. Tudo isso só aconteceu porque existiu uma história que culminou nessa realização. Ao que tudo indica, essa história começou no Instituto de Matemática e Estatística da Universidade de São Paulo em 2003, quando decidi cursar a disciplina de Leitura Dramática oferecida como optativa do curso de graduação em Ciência da Computação. Esse curso proporcionou mudanças e benefícios extremamente relevantes, mas o que é relevante para esse trabalho foi ter tido visão de que eu queria fazer um trabalho de mestrado relacionado com aspectos humanos da Computação.

A partir desse primeiro curso, trabalhei mais quatro anos como ator de teatro e me embrenhei em várias atividades humano-artísticas como música, poesia, desenho, dança, meditação, com o

\footnotetext{
${ }^{4}$ Vide Seção 2.5.1.
} 
objetivo de encontrar as possíveis ligações dessas modalidades com a Computação.

Após algumas tentativas de achar um tema próprio da área de Computação (como algoritmos, orientação a objetos, sistemas) para poder apresentar ao meu orientador, Fabio Kon, expus a ele minha vontade de trabalhar com temas humanos dentro do instituto. Ele me recomendou o livro Fearless Change - Patterns for Introducing new Ideas [RM05] e foi a partir desse livro que todas as outras ideias foram surgindo e se encaixando.

As contribuições originais desta dissertação são:

- Levantamento e descrição de casos reais de aplicações dos padrões.

- Identificação de quatro novos padrões no Capítulo 3.

- Um ensaio sobre a relação entre padrões para introduzir novas ideias e a utilização de atividades artísticas em benefício do desenvolvimento de software ${ }^{5}$.

- Uma análise sobre os sete anos da disciplina de "Leitura Dramática" no IME-USP sob a supervisão da Profa. Jolanda Gentilezza.

- Levantamento e análise de casos de uso de atividades artísticas na indústria de software.

\section{Convenções de formatação}

Ao longo desta dissertação apresentaremos, para alguns padrões, casos de experiências reais. Esses casos serão mostrados em quadros como o seguinte:

\section{Título da Experiência}

Alguns parágrafos contando a história no qual o padrão foi vivido.

Em alguns padrões, replicaremos histórias contadas pelas próprias autoras do livro [RM05]. Nesses casos, apresentaremos as histórias em parágrafos em itálico.

\footnotetext{
${ }^{5}$ Ler introdução no Capítulo 4.
} 
Lista de Tabelas 


\section{Introdução}

A indústria de software tem sofrido grandes transformações na última década. Técnicas e metodologias de desenvolvimento que até pouco tempo atrás eram vistas como fundamentais para o sucesso de um projeto de software começaram a ser questionadas. Um dos principais acontecimentos foi o surgimento dos Métodos Ágeis de desenvolvimento de software, iniciado com o Manifesto Ágil $\left[\mathrm{BBvB}^{+} 01\right]$, cuja filosofia é centrar o foco nas relações humanas inerentes ao desenvolvimento de sistemas e não só nos artefatos e documentos burocráticos preconizados pelas metodologias tradicionais.

Para desenvolver software é preciso conhecer uma linguagem de programação. Uma linguagem de programação não é nada mais do que uma forma de especificar comandos que obedecem a uma certa sintaxe, comandos conhecidos pelo programador e que são interpretados logicamente pelo computador [Set02]. Programar, assim como muitas outras atividades envolvendo o uso de computadores, é uma atividade matemática, mental, lógica. A tendência de parte das pessoas que realizam esse tipo de trabalho sozinhas é o isolamento, a substituição das relações humanas pela relação com computadores e documentos burocráticos. Essa tendência é incentivada pelas metodologias tradicionais.

As metodologias antigas criaram processos e ferramentas para tentar dar às lideranças das empresas de software uma maneira de gerenciar sua mão de obra. Essas ferramentas não levaram em conta que desenvolver software sozinho (uma atividade matemática, mental, lógica) é muito diferente de desenvolver software em equipe. Mas hoje em dia, todos os grandes projetos de software são desenvolvidos em equipe, pois são compostos de milhares de linhas de código que não podem ser escritas por uma única pessoa. Trabalhar em equipe significa lidar com seres humanos, dividir tarefas, lidar com emoções e sentimentos.

Os Métodos Ágeis [Coc06] trazem para o mundo da Computação uma visão mais humana dos desenvolvedores. Empresas tradicionais e consolidadas, que cresceram desenvolvendo software sem adotar uma metodologia específica, podem ter dificuldade para continuar crescendo se o custo de manutenção do sistema legado cresce rapidamente junto com a empresa. O lado humano das metodologias ágeis unido às técnicas também humanas contidas nos padrões apresentados neste 
trabalho podem ser uma saída para produzir, nesse tipo de empresa, uma mudança suave e eficaz.

Para que uma corporação toda mude sua forma de trabalho, é preciso, primeiramente, que ela tenha consciência de que seus processos e métodos atuais não funcionam mais. Em segundo lugar, mesmo que a corporação saiba dos problemas que enfrenta, não é trivial para ela perceber uma solução para seus problemas. E mesmo que alguém dentro da empresa consiga vislumbrar uma possível solução, essa pessoa terá um enorme trabalho para conseguir implantar sua ideia.

Esta dissertação tem dois objetivos. O primeiro é o de fornecer ferramentas e técnicas para alguém que possui uma ideia nova e não sabe o caminho para colocá-la em prática. As técnicas apresentadas foram compiladas como padrões. O segundo objetivo é mostrar que a Arte pode trazer muitos benefícios para programadores. Nem todas as soluções de software estão no plano racional e técnico. Se nos perguntarem qual foi a especialização que a escrita desta dissertação nos trouxe, diríamos que hoje somos especialistas em como o desenvolvimento de software está ligado à Arte.

Apesar de este ser um trabalho científico, assumimos algumas limitações da Ciência, como o próprio fato de, algumas vezes, ela supor que é a única detentora da verdade. A Ciência que não se questiona não é Ciência. Grandes descobertas só foram feitas porque cientistas questionaram os paradigmas da Ciência aceita até então e propuseram uma nova forma de encarar a realidade. Einstein não tinha por objetivo destruir a mecânica clássica de Newton. Ele apenas questionou aquela teoria e mais tarde mostrou que ela estava incompleta [Kuh07].

Neste trabalho defendemos o ponto de vista de que desenvolver software, além de ser uma Ciência, é também uma Arte. Por esta razão, um programador é um criador e deve ser treinado não só estudando demonstrações, técnicas e teorias científicas, mas também com atividades e vivências do campo artístico. A Ciência (ou o método científico) possui algumas limitações; Richard P. Gabriel indica alguns elementos que mostram essas limitações da Ciência [Gab04]:

1. Problema de demarcação: nem sempre é possível saber quando uma teoria é melhor do que a outra. Muitas vezes é difícil saber qual delas é realmente Ciência e qual não é.

2. Positivismo: a visão de que questionamentos científicos sérios não deveriam procurar causas provenientes de alguma origem externa, mas sim limitar-se ao estudo das relações existentes entre fatos que são diretamente acessíveis à observação.

3. Autoritarismo elitista: o problema de demarcação é levado a um júri de cientistas aceitos (elite), que julgam se um trabalho é científico ou não (os congressos científicos, por exemplo, funcionam assim).

4. Anarquismo Epistemológico: não existem regras metodológicas úteis ou livre de exceções que governem a Ciência ou o desenvolvimento do conhecimento. A ideia de que Ciência pode 
ou deve operar de acordo com regras fixas e universais é irrealista e perniciosa, indo contra a própria Ciência [Fey07].

\section{Indutivismo:}

- Uma questão é científica se for provada por fatos e, a partir dos fatos, cria-se uma proposição.

- Mostrando-se que um fato é verdadeiro num determinado contexto, somos induzidos a pensar que ele é verdadeiro em todos os contextos.

- Uma questão só é científica se for provável (ou uma teoria é melhor do que outra se for mais provável).

- Como o universo é enorme, a maioria das probabilidades são pequenas.

6. Convencionalismo: a ideia de que uma teoria científica possa ser uma convenção criada e acordada por algumas pessoas para que se possa fazer alguns cálculos e estudos subsequentes, ou seja, novas decisões são tomadas a partir de outras decisões tomadas anteriormente. Por exemplo: será que a mecânica quântica é uma forma de convencionalismo?

Essas limitações não diminuem de maneira alguma a importância da Ciência. Apenas nos levam a procurar outras formas de descoberta que podem completá-la. A Arte seria uma boa candidata para complementar as limitações da Ciência. No Capítulo 4, mostramos como as várias formas de manifestação artística se relacionam com a Ciência e o desenvolvimento de software.

Vamos então à primeira parte do nosso trabalho: falar de padrões e, mais precisamente, Padrões para Introduzir Novas Ideias.

\subsection{Padrões}

Um padrão pode ser visto como um documento que descreve um problema e uma possível solução já pensada por alguém. O padrão normalmente também descreve o contexto em que o problema é encontrado e quais são as vantagens e desvantagens de aplicar a solução proposta num contexto similar. A solução apresentada pelo padrão não é a única existente e não há garantia de que seja a melhor, mas por já ter sido experimentada algumas vezes com sucesso, pode ser considerada uma solução satisfatória.

O arquiteto Christopher Alexander definiu um padrão como uma regra de três partes que expressa a relação entre um certo contexto, um problema e uma solução [AIS $\left.{ }^{+} 77\right]$. Richard $\mathrm{P}$. Gabriel complementou essa definição para o ambiente de software, dizendo que cada padrão é uma regra de três partes que expressa a relação entre um certo contexto, um certo sistema de forças que 


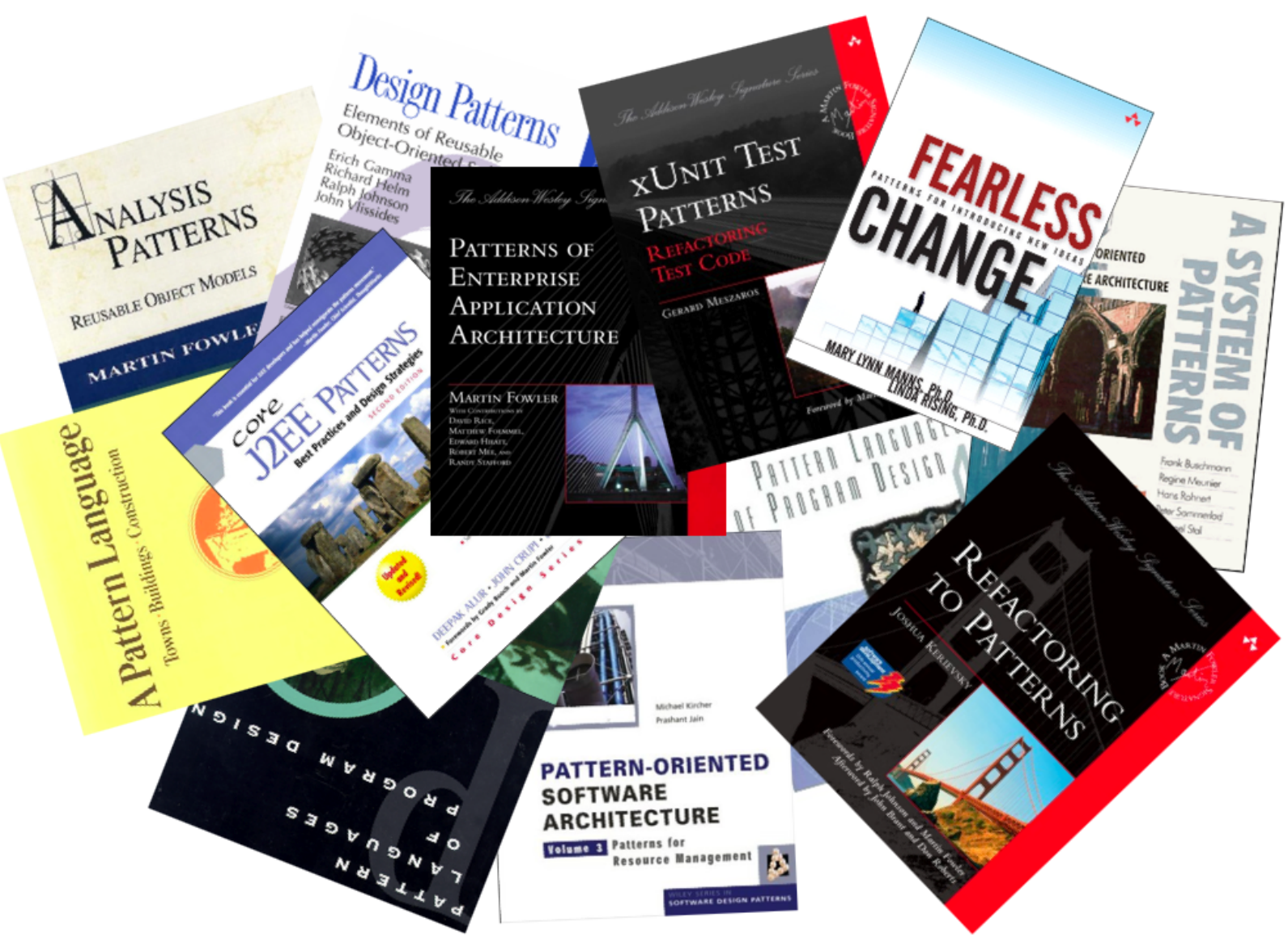

Figura 1.1: Literatura sobre Padrões

ocorre repetidamente neste contexto e uma certa configuração de software que permite que essas forças se resolvam [Cru01]. Martin Fowler nos trouxe uma outra definição mais simples: um padrão é uma ideia que foi útil em algum contexto prático e provavelmente será util em outros [Fow97].

Padrões não são invenções de algo novo. Apenas são observados pela experiência e escritos numa estrutura definida; padrões transformam conhecimento tácito em conhecimento explícito. Eles existem em diferentes níveis de abstração e o seu uso previne que se "reinvente a roda". Quando aparece um problema num determinado contexto cuja solução já é conhecida em um outro contexto semelhante e identificada por algum padrão, basta usar essa solução. Ou seja, são artefatos reutilizáveis, que comunicam designs e boas práticas. Normalmente, são catalogados e podem ser 
usados em conjunto com outros padrões para resolver problemas maiores. Cada padrão é uma forma de capturar experiência. A palavra "padrão" se refere a uma boa prática recorrente documentada como uma solução para um problema num dado ambiente.

Nas últimas décadas, a comunidade de software desenvolveu muitos trabalhos envolvendo padrões. Em 1994, foi realizada a primeira PLoP (Annual Conference on Pattern Languages of Programs [plo94]), uma conferência internacional criada exclusivamente para escrita e refinamento de padrões. Nessa conferência são realizadas várias dinâmicas de grupo, entre elas a renomada Oficina de Escritores (Writer's Workshop [Gab02]). Alguns exemplos de padrões na literatura são: Padrões de Projeto [GHJV95], Arquitetura de Software Baseadas em Padrões [BMR ${ }^{+}$96], a série Linguagens de Padrões para Projeto de Software [VCK96] [MRB97] [HFR00] [MVN06], Padrões de Arquitetura para Aplicações Corporativas [Fow03], Padrões para Testes de Unidade [Mes07], Padrões para Refatorações de Bancos de Dados [AS06], Padrões para Escrever Padrões, entre outros.

No Capítulo 2, abordaremos padrões que foram criados para facilitar a aceitação de uma nova ideia dentro de uma corporação. Examinaremos os Padrões para Introduzir Novas Ideias [RM05], compilados por Linda Rising e Mary Lynn Manns.

\subsection{Arte e Trabalhos Relacionados}

Unir Arte com a Ciência da Computação não é algo muito comum, daí a dificuldade de se encontrar trabalhos que relacionam esses dois temas aparentemente desconexos. Citamos, então, algumas referências de autores que já trataram de alguma forma de como a Ciência e a Computação se relacionam com a Arte.

Como um dos objetivos dessa dissertação é mostrar os benefícios da Arte para o desenvolvimento de software, vamos fazer uma pequena reflexão sobre o conceito do que seria Arte e qual as relações entre Arte e a Ciência. Nos primórdios das Comunicações da ACM, em 1959, os editores destacaram o seguinte objetivo para os periódicos da ACM [BJP59]:

"Se a programação de computadores irá se tornar uma área importante na pesquisa e desenvolvimento da computação, uma transição da programação de Arte para Ciência deve ser feita."

Donald Knuth, que escreveu um dos livros mais famosos da Computação: The Art of Computer Programming [Knu97], afirmou que a programação deixou de ser uma Arte para tornar-se Ciência por uma simples razão: começamos a chamá-la de "Ciência da computação" [Knu74].

A palavra Arte vem do Latin ars, que significa "habilidade". A palavra Grega correspondente seria $\tau \varepsilon \chi \nu \eta$, raiz das palavras "tecnologia" e "técnica". Existiram épocas em que a humanidade 
não distinguia Arte de Ciência. As pessoas na idade média ensinavam as artes ciências liberais, que eram as mesmas que as sete ciências liberais (gramática, retórica, lógica, aritmética, geometria, música e astronomia), das quais três têm bastante relação com a computação de hoje.

Knuth ainda diz que

"Ciência seria o conhecimento que compreendemos tão bem que conseguimos ensinálo a um computador; se você não compreende algo totalmente, então seria uma Arte lidar um isso [...] Existe uma distância enorme entre o que os computadores podem fazer e o que as pessoas podem fazer. As visões incríveis que as pessoas têm quando falam, escutam, criam ou mesmo quando programam estão longe do alcance da Ciência; quase tudo ainda é uma Arte [...] A Ciência sem a Arte é suscetível a se tornar ineficaz; a Arte sem a Ciência é suscetível a se tornar imprecisa [...] Precisamos combinar Ciência com valores artísticos se quisermos progredir de verdade"[Knu74].

Existe na literatura vários casos que misturam (e confundem) as palavras "Arte" e "Ciência". Por exemplo, existe o livro The Art of Piano Playing [NL93] e The Art of Playing the Piano Forte [Hum92], mas também podemos encontrar The Science of Pianoforte Technique [Fie34], ou ainda The Art of Piano Playing: a Scientific Approach [Koc67]. Podemos citar também The Science of Being and Art of Living [Yog63].

Alvin Toffler disse (apud [Cis05]):

"A sociedade precisa de todos os tipos de habilidades que não são somente cognitivas; elas são emocionais, elas são afetivas. Você não pode dirigir uma sociedade somente com dados e computadores."

Peter Brook, um famoso teatrólogo também argumenta [OM98] que

"Nos dias de hoje, a tragédia da Arte é que nela não há Ciência; e a tragédia da Ciência é que nela não há emoção."

Albert Eisntein tinha a opinião de que "depois que um certo nível de conhecimento técnico é atingido, Ciência e Arte tendem a coalescer em estética, plasticidade e forma. Os maiores cientistas são artistas também". Em A Short Introduction to The Art of Programming [Dij71], Dijkstra diz que programação envolve bom gosto e estilo e que um professor não deve ensinar um aluno a escrever um determinado programa, mas ajudar os pupilos a encontrarem seus próprios estilos.

Em The Mythical Man-Month: Essays on Software Engineering [Bro95], Frederick Phillips Brooks compara o pensamento de um programador ao de um poeta, dizendo que ambos trabalham ligeiramente afastados de coisas que são pensamento puro. Richard P. Gabriel afirma que todo programador deveria ser treinado como artista [Hei02]. Paul Graham cita várias semelhanças entre 
programação e pintura [Gra04]. Se computação é uma Ciência e uma Arte ao mesmo tempo, deveríamos incluir mais Arte no dia-a-dia de alunos de computação, como sugere o Prof. Valdemar Setzer em Um Antídoto Contra o Pensamento Computacional [Set06a]. A famosa astronauta Mae Jemison também concorda que deveríamos unir as ciências com as artes [Jem06].

Em The Art in Computer Programming [HT01], Dave Thomas e Andy Hunt mostram como programar é muito mais do que lidar com máquinas. É preciso conhecer o ser humano e interpretar suas vontades, indo além do que foi pedido por ele. Precisamos fazer as perguntas certas para o cliente descobrir o que ele realmente precisa. Isso é um trabalho de Arte.

Pete McBreen em Software Craftsmanship - The New Imperative Design [McB02] vê o desenvolvimento de software como habilidade artesanal que mistura sutilmente Arte, Ciência e engenharia, com o objetivo de entregar sistemas efetivos. Robert C. Martin (também conhecido na comunidade de software como "Uncle Bob") também afirma em Clean Code: A Handbook of Agile Software Craftsmanship [Mar08] que, resumindo, "um programador que escreve código limpo é um artista que, através de uma série de transformações, leva uma tela em branco a um sistema elegantemente codificado."

Como podemos perceber, existem muitos trabalhos que mostram relações entre Arte e Ciência da Computação. A união dessas duas disciplinas aparentemente distintas podem trazer benefícios tanto para a Ciência quanto para a Arte e, consequentemente, para a humanidade. 


\section{Padrões para Introduzir Novas Ideias}

Um método ágil que ficou muito conhecido e que vem sendo usado atualmente tanto no meio acadêmico quanto na indústria [Inc08] é a Programação eXtrema (XP) [Bec99]. Introduzir XP nas empresas não é uma tarefa trivial. Não basta ensinar as práticas da metodologia para os colaboradores, pois as práticas se baseiam em valores e princípios que algumas vezes são contrários a valores da própria empresa. Por exemplo, XP sugere a programação em pares. Para isso, as pessoas precisam sentar juntas em frente a um mesmo computador e discutir sobre o problema que estão tentando resolver. Num ambiente de trabalho onde as pessoas não estavam acostumadas a discutir problemas (acreditemos ou não, isso existe), fazê-las mudar de postura pode ser um choque. Implantar XP, principalmente em empresas já consolidadas, significa implantar profundas mudanças culturais e essa tarefa pode durar meses, ou até anos.

Os padrões listados neste trabalho não são ideias novas e nem revolucionárias. O leitor muito provavelmente se identificará com vários padrões listados e dirá "Ah, isso eu já usei". O principal objetivo é documentar práticas de sucesso conhecidas para que elas possam ser usadas por outros. Além do nome do padrão em português, criado por nós, será também apresentado para cada padrão o seu nome original em inglês. O nome do padrão é algo muito forte. Ele resume em uma ou duas palavras toda uma ideia. Muitos nomes não possuem traduções literais. O conhecimento do nome original pode ajudar o leitor a entender ainda mais o padrão.

Um dos objetivos deste trabalho é conhecer profundamente os padrões documentados por Linda Rising ${ }^{1}$ e Mary Lynn Manns ${ }^{2}$ [RM05]. Linda tinha o objetivo de implantar o uso de Padrões de Projetos [GHJV95] numa organização. Para tentar influenciar as pessoas, ela usou os Padrões para Introduzir Novas Ideias. Essas técnicas de influenciar pessoas (Padrões para Introduzir Novas Ideias) foram usados por nós para introduzir as ideias da metodologia XP dentro de uma corporação. Faremos uma análise de cada padrão, como ele foi usado e as experiências obtidas. Faremos um resumo desses padrões, relacionando o seu uso com a introdução de Métodos Ágeis em empresas

\footnotetext{
${ }^{1}$ Ph.D. pela Universidade do Estado do Arizona, consultora em desenvolvimento de Software, muito conhecida na comunidade de padrões, possui vários livros publicados sobre o assunto

${ }^{2}$ professora da Universidade da Carolina do Norte, realizou seu trabalho de doutorado com foco na introdução de padrões dentro de organizações
} 
de software.

Iremos apresentar os padrões divididos em algumas categorias.

- As pessoas - quem são as pessoas com as quais iremos interagir?

- Por onde começar - alguns padrões de uso rápido, por onde podemos começar nosso trabalho?

- O que fazer em seguida - uma vez que já começamos o trabalho e que alguns resultados começam a aparecem, como devemos prosseguir?

- Encontros e reuniões - como organizar e obter benefícios com esses eventos?

- Em ação - quando as novas ideias já estão espalhadas e queremos agir para que elas se fixem.

- Tudo são pessoas - mais alguns padrões sobre como lidar com as pessoas.

- Um novo papel: agora você é dedicado - quando a tarefa de introduzir uma nova ideia se torna oficialmente o seu trabalho.

- Convencendo as massas - como convencer grande quantidade de pessoas?

- Estratégias para influenciar - mais alguns padrões para influenciar as pessoas a adotarem uma nova ideia.

- Continue Caminhando - quando você atingir seu objetivo inicial, como continuar para que as pessoas não voltem atrás?

- Lidando com Resistência - como lidar com aquelas pessoas que nunca aceitarão a nova ideia?

A descrição de alguns padrões possui um texto em itálico no início. Esse formato foi usado pelas autoras para contar uma pequena história relacionada ao padrão antes de explicá-lo. 


\subsection{As Pessoas}

Antes de mais nada, é preciso lembrar que para introduzir uma ideia iremos lidar com pessoas. Os primeiros padrões que precisamos conhecer são, então, os padrões relacionados a pessoas. Você deve estar preparado para saber como elas aceitarão suas ideias, quem poderá lhe ajudar e quem irá atrapalhar, como interagir com as várias personalidades que irão passar pelo seu caminho. Esta seção é dedicada a descrever Pessoas. A seguir apresentaremos quem são as pessoas que você encontrará pelo caminho, sob o ponto de vista da aceitação para novas ideias.

\subsubsection{Inovador (Innovator)}

Os Inovadores são uma pequena parcela da população - por volta de $2,5 \%^{3}$. Eles aceitam novas ideias rapidamente. Com eles não é preciso muita persuasão. Eles se empolgam com as coisas só pelo fato de serem novas. São pessoas que gostam ainda mais das coisas que não funcionam direito. O interesse deles por novidades permite que você os use para lhe ajudar a testar suas ideias. Mas eles não ficarão interessados por muito tempo. Por sua natureza aventureira e aberta a arriscar, os outros normalmente não aceitam muito suas ideias. Logo, Inovadores são excelentes para ajudar no início de um trabalho, mas não muito bons formadores de opinião.

\subsubsection{Os que Adotam Cedo (Early Adopter)}

Os que Adotam Cedo representam uma parte maior da população - por volta de 13,5\%. Eles também são abertos a novas ideias, mas só irão aceitá-las depois de uma análise mais aprofundada. Eles tendem a olhar para a oportunidade estratégica que uma inovação pode trazer e podem ser persuadidos se enxergarem que sua ideia é uma grande descoberta. Os que Adotam Cedo são visionários motivados, respeitados pelos parceiros. Ele podem servir como formadores de opinião quando aceitarem a ideia. Porém, os Inovadores e Os que Adotam Cedo são um grupo pequeno. Para ter impacto, você deve convencer a maioria.

\subsubsection{Primeira Maioria (Early Majority)}

A Primeira Maioria é o primeiro grupo significativo (por volta de um terço da população) a aceitar a nova ideia. Eles interagem bastante com os colegas de trabalho, mas raramente são líderes. Eles tendem a seguir e querem a garantia de que outros já tiveram sucesso com a ideia antes de adotá-la para si. Como são pragmáticos, são convencidos se a inovação puder trazer melhorias mensuráveis, previsíveis e incrementais. Uma vez que esse grupo está convencido, as raízes da

\footnotetext{
${ }^{3}$ As porcentagens da população em cada grupo foram extraídas de um estudo realizado por Rogers [Rog95]. Esse estudo é baseado em populações dos campos rurais, da educação, da saúde e de sociedades antigas.
} 
inovação estão plantadas. Essas pessoas são a ligação entre Os que Adotam Cedo e a Última Maioria. Eles são a sua ponte entre o velho e o novo.

\section{Última Maioria (Late Majority) e Retardatários (Laggards)}

A Última Maioria é o segundo grupo significativo (por volta de um terço da população) a aceitar a nova ideia. É composto por pessoas que aceitam novas ideias com ceticismo e cautela. São conservadores por natureza e só podem ser convencidos depois que toda incerteza se foi. Eles precisam de uma certa pressão para aceitar a nova ideia. Essa pressão pode vir de várias formas: vendo as pessoas a sua volta usando a ideia, um chefe sugerindo o uso ou o time adotando-a, fazendo com que eles também adotem para poder trabalhar eficientemente com o time.

Os Retardatários são os últimos a adotar a nova ideia - isso quando eles chegam a aceitá-la. Sua visão é tipicamente "nós sempre fizemos desta maneira". Seus amigos tendem a ser também Retardatários. Pelo fato deles suspeitarem da inovação e mudança, sua aceitação normalmente vem com extrema pressão de outros, junto com a absoluta certeza de que a ideia não vai falhar.

\section{Um pouco mais de XP e os impactos culturais nos retardatários}

XP não resolve todos os problemas de uma organização. Seu principal foco é o desenvolvimento de software. A Programação Extrema não resolverá problemas das áreas de marketing, vendas ou recursos humanos. Porém a adoção dessa metodologia acarreta mudanças em toda empresa. Vamos mostrar porque isso acontece. Para isso usaremos o exemplo da Teoria das Restrições [GC02], mostrada no livro Extreme Programming Explained - Second Edition (Kent Beck) [BA04].

Suponha que você tenha uma lavanderia como a da Figura 2.1: Sua lavadora de roupas demora 45 minutos para limpar as roupas, a secadora 90 minutos para secar. Passar roupas demora 15 minutos. O gargalo desse processo está na secadora. Mesmo que você compre mais

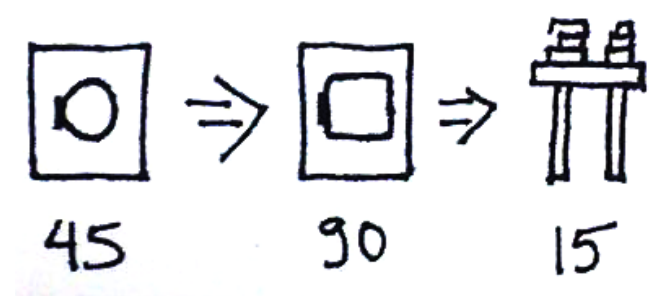
uma lavadora, não conseguirá ter mais roupas terminadas. Pode ser que tenha mais roupas lavadas temporariamente, mas terá que arma-

Figura 2.1: Estado inicial do processo da lavanderia zená-las em algum lugar durante um tempo até que a secadora termine o trabalho anterior.

A Teoria das Restrições diz que num sistema existe uma restrição (gargalo) por vez. Para melhorar o processo como um todo, você precisa encontrar onde está a restrição.

Como encontrar restrições e eliminá-las? O trabalho se acumula nos pontos de restrição. A secadora é um gargalo. Para melhorar meu processo de lavagem, preciso aumentar a velocidade de 
secagem. Posso comprar uma secadora nova. Posso usar uma lavadora que centrifuga a roupa e diminui o tempo de secagem. Ou posso estender a roupa num varal como da Figura 2.2.

Uma vez eliminada uma restrição, outro gargalo surgirá no processo e deverá ser otimizado.

Em desenvolvimento de software, os gargalos precisam ser identificados. No processo tradicional (cascata) [Roy70] temos o Levantamento de Requisitos, seguido da Especificação, seguido da Implementação e por último os Testes. Se existirem pilhas de funcionalidades não implementadas, o gargalo está na implementação. Se há muitas funcionalidades implementadas esperando para serem testa-

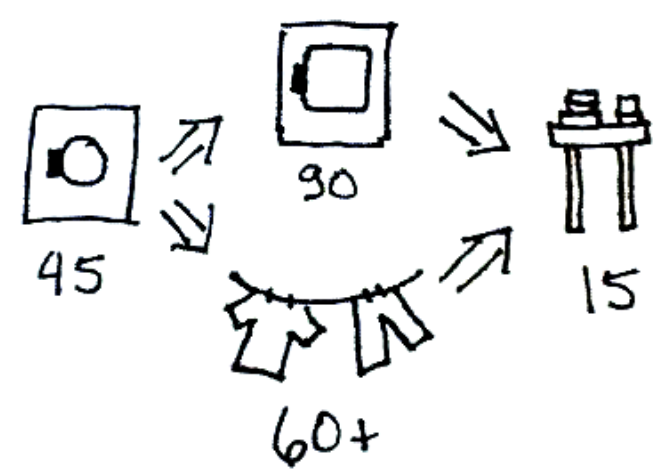
das, o gargalo está nos testes e assim por diante. Esse modelo é conhecido como "push". XP usa o modelo "pull" (Figura 2.3)

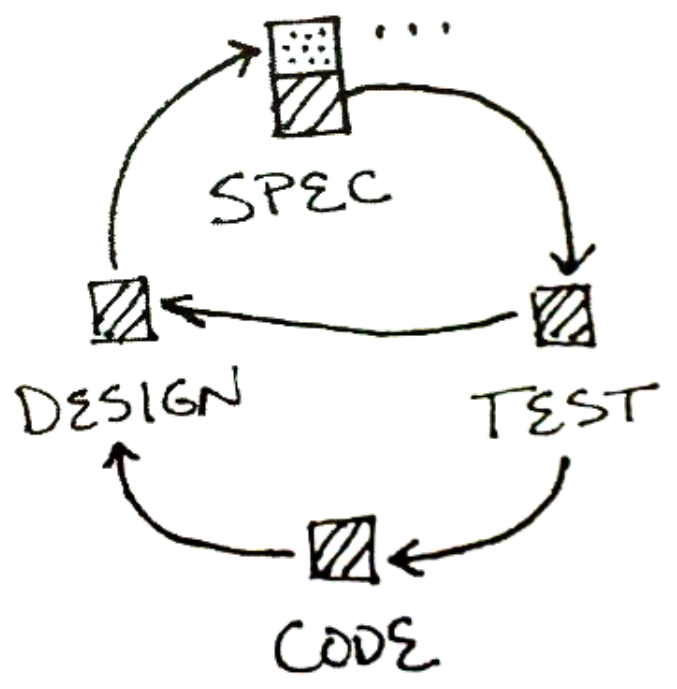

Figura 2.3: Modelo "pull" de desenvolvimento

Os requisitos (histórias) são especificados em detalhes apenas imediatamente antes de serem implementadas. Os testes são extraídos ( pulled) da especificação. A interface é definida para satisfazer os testes. O código é escrito para satisfazer a interface e os testes. O design é refinado para atender às necessidades do código.

A Teoria das Restrições [GC02] é interessante para ajudar a identificar qual é o seu processo. Vale ressaltar que o desenvolvimento de software é um processo humano, não uma fábrica. Não pense nas pessoas como caixas bem definidas e previsíveis desse processo.

O uso de XP na empresa pode trocar o gargalo do processo para algum lugar fora da área de desenvolvimento de software. Por isso, XP pode afetar toda a empresa quando ela resolve adotar a metodologia. Por exemplo, se os programadores começarem a implementar mais rápido do que o time de produtos consegue especificar, o gargalo vai parar no time de produtos. Beck conta que algumas vezes equipes de software produtivas são tristemente despedidas e XP eliminado, pois traz 
à tona ineficiências em outras áreas da empresa [BA04]. Daí a importância de ter o apoio de algum alto executivo que defenderá a metodologia perante outras áreas.

Muitas vezes, os retardatários serão os maiores impactados pela mudança cultural. O gargalo do processo poderá cair justamente sobre eles e, nesse momento, sentindo-se ameaçados, eles serão os primeiros a depor contra a nova forma de trabalho.

\subsection{Por onde começar?}

Para começar a implantar uma nova ideia, você precisará ser um Evangelista. O termo sugere algo religioso, remetendo à ideia de fé. Será impossível para você espalhar uma ideia se você não acredita nela. Essa seção contém um pequeno conjunto de padrões que você poderá usar de início, um Canivete Suíço de padrões para introduzir novas ideias.

\subsubsection{Evangelista (Evangelist)}

Você é um Evangelista. Para introduzir sua nova ideia dentro da organização, faça tudo que puder para compartilhar sua paixão por essa ideia. Você quer que sua ideia se espalhe pela empresa, mas não sabe muito bem por onde começar. Deixe que sua paixão por essa ideia guie você. Estar apaixonado significa viver cada segundo com a ideia presente em suas ações e pensamentos. A sua ideia não é simplesmente uma tarefa a ser realizada, mas a manifestação de sua própria essência.

Divida com as pessoas o seu entusiasmo por essa novidade. Tenha em mente que você não é tão experiente no assunto. Um pouco de humildade o levará longe. Lembre-se também de que você não é a ideia. Você é apenas uma pessoa que tem uma boa ideia, mas que pode compartilhar com outras pessoas. Você não perde nada se outras pessoas também se tornarem Evangelistas, então encoraje-as a serem.

Pesquisas sugerem que se você é naturalmente atraente e as pessoas gostam de você, seu trabalho será mais fácil porque as pessoas são inconscientemente mais abertas às pessoas que elas gostam. Você precisa ser um grande comunicador, extrovertido e ter credibilidade.

O risco desse padrão é que você se torne tão apaixonado pela nova ideia que acabe afastando algumas pessoas. Mantenha o entusiasmo, mas não se deixe levar totalmente e principalmente não deixe que o entusiasmo o torne impaciente. Não deixe também que sua paixão o impeça de enxergar as limitações e os problemas de sua ideia. Não há nada pior do que uma fé cega numa ideia, por melhor que seja a ideia. 


\subsubsection{Experimente a Água (Test the Waters)}

Quando uma oportunidade surgir, teste se existe interesse pela sua ideia usando alguns desses padrões e avaliando os resultados. Escolha dois ou três padrões dessa coleção e use-os. Para a maioria das pessoas, o processo de mudança é como mergulhar lentamente a ponta dos pés na água para sentir se ela está muito fria.

Tente começar por coisas que não exigem muito esforço, como Toque Pessoal ${ }^{4}$, Simplesmente Faça ${ }^{5}$, Saco de Papel $^{6}$, Piggyback ${ }^{7}$ e Plante as Sementes ${ }^{8}$. Esteja preparado para desapontamentos. Algumas vezes a ideia é muito nova ou radical para ser aceita na primeira tentativa.

\subsubsection{Tempo para Reflexão (Time for Reflection)}

Aprenda sobre o passado reservando, periodicamente, um tempo para reflexão sobre o trabalho. Avalie o que deu certo e o que deu errado. A pausa é um momento importante num trabalho. Se trabalhássemos incessantemente, produzindo sem parar, não teríamos condições de saber se o que estamos produzindo está realmente de acordo com as nossas expectativas. Além disso, o contexto, as pessoas e os objetivos mudam ao longo do tempo. Não parar para refletir pode significar não perceber essas mudanças e rumar por um caminho indesejado.

A metodologia ágil Crystal [Coc04] tem como prática refletir sobre o trabalho. No final de cada iteração, o time se reúne e escreve um cartaz dividido em três quadrantes: "manter", "melhorar" e "encafifamentos". No quadrante "manter" são colocadas as práticas e soluções que a equipe considera ter feito com excelência e que deseja manter para as próximas iterações. No quadrante "melhorar" são apontadas as falhas da equipe, práticas que não foram seguidas adequadamente e que podem ser melhoradas nas próximas iterações. Os "encafifamentos" ("fuzzles") são coisas que deixaram a equipe perdida, em dúvida, sem saber muito bem qual a melhor maneira de solucionar um determinado problema. Apesar dessa prática ter sido criada na metodologia Crystal, equipes de XP têm o costume de usá-la em suas iterações. Refletir faz parte dos Métodos Ágeis [dS07], onde as pessoas e as interações entre elas são mais importantes do que processos e ferramentas $\left[\mathrm{BBvB}^{+} 01\right]$.

\footnotetext{
${ }^{4}$ Vide Seção 2.6.1.

${ }^{5}$ Vide Seção 2.5.1.

${ }^{6}$ Vide Seção 2.4.2.

${ }^{7}$ Vide Seção 2.4.1.

${ }^{8}$ Vide Seção 2.4.5.
} 


\subsubsection{Pequenos Sucessos (Small Successes)}

Para evitar a fadiga dos desafios e todas as coisas que precisa fazer quando está realizando uma mudança, comemore até mesmo pequenos sucessos. Para manter a motivação, qualquer passo adiante é motivo para comemorar. Toda mudança organizacional tem seus altos e baixos. É um processo difícil. Muitas vezes nos preocupamos apenas com a "grande vitória" e nos esquecemos que toda a guerra é vencida em pequenas batalhas.

Realize suas ações Passo a Passo ${ }^{9}$ e tire um tempo para comemorar sucessos, especialmente os pequenos. O sucesso vem de vários lugares. Olhe para ele. Pergunte-se no final da semana o que o time aprendeu ou fez diferente. Foque nos ganhos e não nas perdas. Mesmo que não tenha conseguido tudo o que queria, ainda pode comemorar quando não aconteceu o que você não queria. Esses momentos de comemoração ajudam a manter as pessoas motivadas, pois trazem à consciência de que passos de sucesso importantes estão sendo dados.

\subsubsection{Passo a Passo (Step by Step)}

Para aliviar a frustração da enorme tarefa de mudar uma organização mova-se aos poucos, passo a passo, em direção ao seu objetivo. Use uma tática incremental em sua iniciativa de mudança, com pequenos objetivos de curto prazo, mantendo a visão do objetivo de longo prazo. Para subir uma escada você não vai direto de baixo para o topo. É preciso subir um degrau por vez. Se você tentar seguir um plano mestre à risca, está quase que certamente fadado ao fracasso. Um dos princípios ágeis é "Saber adaptar-se é mais importante do que seguir um plano inicial" [BBvB $\left.{ }^{+} 01\right]$. Isso não significa que não devemos fazer planos. Os planos são muito importantes para conseguirmos organizar nossas atividades, mas não precisamos ser paranóicos em realizar tudo que foi planejado a risca. Como disse o 34o. presidente dos Estados Unidos, Dwight David Eisenhower [Lee02]:

"Planos não são nada, planejar é tudo."

Mudanças levam tempo. Você deve respeitar o tempo da mudança, respeitar o tempo que as pessoas precisam para mudar. O ser humano tem um medo natural das mudanças. Ajude todos a vencer esse medo, trabalhando determinado, mas com paciência e respeito. Encoraje as pessoas a usarem uma Rodada de Testes $^{10}$ mesmo para uma pequena parte da nova ideia. Antes de seguir com pressa, dê um passo para trás, acalme-se. Pense em causar o mínimo de perturbação e ainda conseguir o resultado esperado.

O trabalho de mudança é longo. Você provavelmente não conhece todos os problemas que vai enfrentar. O caráter incremental desse padrão permite que você aprenda enquanto avança.

\footnotetext{
${ }^{9}$ Vide Seção 2.2.5.

${ }^{10}$ Vide Seção 2.8.1.
} 
Algumas pessoas podem pensar que você não sabe onde quer chegar. Tente mostrar a elas que o objetivo e o caminho que leva a ele não são a mesma coisa. Noé não esperou começar a chover para construir a arca. 


\subsection{0 que Fazer em Seguida?}

Você está trabalhando arduamente e tornando-se conhecido como Evangelista no seu pequeno círculo. Agora é hora de ir adiante. Você precisa fortalecer seu arcabouço de padrões. Nesta seção, discutimos alguns padrões que ajudarão a espalhar a sua influência: você reconhecerá o poder de Pedir Ajuda ${ }^{11}$ e Diga Obrigado ${ }^{12}$.

\subsubsection{Conectores (Connector)}

Existem algumas pessoas que têm conexões com muita gente dentro da organização. A empresa é muito grande e dificilmente você conseguirá falar com todos pessoalmente. Vários estudos indicam a importância das redes informais. Secretárias são peças chave. Elas provavelmente sabem o nome e o gosto pessoal de muita gente. Converse com a secretária sobre as suas ideias, mesmo que ela não entenda exatamente o que você pretende. Fale informalmente, numa pausa do trabalho, num café. Naturalmente suas ideias se espalharão pela corporação, principalmente se os Conectores ${ }^{13}$ simpatizarem com elas.

\subsubsection{Guru ao Seu Lado (Guru on Your Side)}

Tenha uma lista de pessoas seniores, com grande conhecimento técnico, que são respeitadas pelos membros da corporação. As pessoas podem relutar em mostrar interesse em uma nova ideia a não ser que ela venha de alguém que elas respeitam. Procure de preferência pessoas que são respeitadas tanto pelos líderes quanto pelos não-líderes. As pessoas são bombardeadas todos os dias por centenas de informações. Elas precisam de um filtro para separar o que é interessante do que é dispensável. Só o fato de uma ideia vir de alguém respeitável já é por si só um filtro positivo.

Aproxime-se dos gurus com humildade. Você está lá para aprender com eles e não para ensinálos. Leve o guru para tomar um café. Tenha com ele uma "conversa de elevador" de dois minutos e esteja preparado para ouvir. Se você for novo na corporação, pergunte aos Conectores ${ }^{14}$ quem são os gurus.

\footnotetext{
${ }^{11}$ Vide Seção 2.3.3.

${ }^{12}$ Vide Seção 2.3.4.

${ }^{13}$ Vide Seção 2.3.1.

${ }^{14}$ Vide Seção 2.3.1.
} 


\section{Quem era o meu Guru?}

Logo que entrei no meu novo trabalho, tinha vontade de contar a todo mundo tudo o que eu sabia. Tinha sede de transmitir conhecimento e ajudar o máximo de pessoas possíveis. Obviamente, essa vontade ia muito além das minhas possibilidades reais de influenciar e ajudar as pessoas. Nem sempre todos estão dispostos a ouvir. Nem sempre nos conhecem suficientemente bem para confiar em nossas argumentações. Minha primeira tentativa de ensinar foi fazendo uma apresentação sobre algumas novidades da plataforma Eclipse, que eu havia acabado de conhecer. Essa apresentação foi aberta a todos.

Algumas pessoas de outras equipes vieram. Dentre elas estava alguém que se tornaria um grande aliado. Depois de bem pouco tempo numa empresa é fácil reconhecer quem é o guru. Era ele. O tempo todo mostrava conhecimento nos mais diversos assuntos abordados. Poucos dias depois de minha apresentação, ele veio com a ideia de criar um grupo de estudos. Assim como eu, era uma pessoa que via na troca de experiências e informações uma das ferramentas mais poderosas que pode haver numa empresa de tecnologia.

Várias vezes ficávamos conversando na copa ou nos corredores da empresa. Quase sempre o assunto era pessoas. Na época todo o departamento de tecnologia estava passando por um momento difícil. O sistema legado empacava o desenvolvimento de novos produtos. As equipes eram enormes e a gerência, centralizada em poucas pessoas que não podiam dar conta de tanta gente.

O meu trabalho era particularmente diferente, pois estava numa área embrionária, numa equipe nova e independente. No nosso caso, o uso de Métodos Ágeis estava dando resultado. O guru já conhecia Métodos Ágeis (claro, o que o guru não conhece?). Ele já havia tentado algumas vezes usar algumas praticas de XP, mas a barreira cultural era muito maior do que pequenas tentativas isoladas de melhorar os processos. Ele havia desistido de tentar mudar alguma coisa.

Depois de um tempo, o grupo de estudos ganhou maturidade. Deixamos a coisa acontecer naturalmente. Mesmo com os sucessos isolados da equipe em que eu trabalhava e a opinião unânime das pessoas do grupo de estudos sobre a eficácia de Métodos Ágeis, a presença do guru foi fundamental. O principal diretor sempre o consultava. O guru tinha a voz mais ouvida em toda área de tecnologia. Se não tivéssemos o aval dele, dificilmente as coisas teriam evoluído. 


\subsubsection{Peça Ajuda (Ask for Help)}

Quando estiver tentando introduzir novas ideias, procure pessoas e recursos que possam lhe ajudar. Introduzir novas ideias não é uma tarefa fácil, especialmente dentro de uma grande corporação. É uma tarefa que dificilmente será feita por uma única pessoa. Normalmente, as pessoas tendem a fazer um determinado trabalho sozinhas em busca de reconhecimento pelo sucesso alcançado. Nesse caso, pedir a ajuda dos outros significa dividir os méritos pelo sucesso de um trabalho. Nem todos estão dispostos a dividir, porém o objetivo principal é introduzir a nova ideia. Quando um grupo de pessoas está envolvido, a ideia se alastra pela corporação com muito mais eficácia.

Quanto mais pessoas puderem ajudar nessa tarefa melhor. Segundo Setzer [Set06b], pessoas têm habilidades e necessidades; a habilidade de um preenche a necessidade do outro e vice-versa. Pedir ajuda é permitir que o outro exercite suas habilidades e se sinta valorizado e respeitado. Ajudar alguém é suprir as necessidades. Essa é a troca inerente ao convívio de seres humanos.

\subsubsection{Diga Obrigado (Just Say Thanks)}

Para mostrar sua gratidão, diga "obrigado" da maneira mais sincera que você puder a todas as pessoas que o ajudarem. As pessoas se sentem desanimadas quando trabalham duro e ninguém percebe. Mesmo que você não tenha recursos para recompensar os ajudantes com algo tangível, uma expressão de gratidão não custa nada e significa muito para quem a recebe.

Mesmo reconhecimentos informais podem causar boa impressão. Um telefonema, um pequeno bilhete ou um presente barato, qualquer uma dessas coisas mostrará que você se preocupou com o que a pessoa que vai receber gosta. Faça com que as pessoas saibam que elas são queridas falando com elas frequentemente. Faça as pessoas se sentirem importantes. Mesmo que a ajuda tenha sido há bastante tempo, continue falando aos outros que você ainda é grato pelo que elas fizeram.

Uma vez que você começa a agradecer as pessoas, pode correr o risco de ofender outros que se sintam deixados de lado, ou que não receberam o mesmo nível de reconhecimento. Tente agradecer igualmente a todos, não dando preferência para quem fez a tarefa principal. Peça desculpas sempre que se esquecer de retribuir a alguém.

\subsection{Encontros e Reuniões}

Umas das formas de espalhar suas ideias é organizar encontros, eventos, reuniões. Nesta seção serão apresentados padrões que sugerem como fazer esses encontros, quem chamar, onde reunir as pessoas, o que levar (ou não levar) para as reuniões. 


\subsubsection{Adendo (Piggyback)}

Ligue sua nova ideia a alguma prática bem aceita na organização. Você pode tentar vender sua ideia como uma versão melhorada de algo que já funciona na empresa. As empresas possuem processos e características culturais que são difíceis de serem mudadas. Se sua nova ideia entrar em choque com esses processos você terá muita dificuldade em colocá-la em prática. Algumas vezes é possível que sua ideia seja introduzida como um adendo a um processo já em uso na corporação. As pessoas terão mais facilidade em aceitar a sua proposta se não a enxergarem como uma total revolução.

\subsubsection{Saco de Papel (Brown Bag)}

Use o horário em que as pessoas normalmente almoçam como um momento convenientemente relaxado para ouvir sobre sua nova ideia. As pessoas estão sempre muito ocupadas para marcar uma reunião durante o horário de trabalho. Porém, todos costumam tirar uma hora de almoço. O horário de almoço é normalmente um horário disponível.

Nos grandes centros urbanos (principalmente nos Estados Unidos) está se tornando cada vez mais comum as pessoas comprarem suas comidas na rua (e levá-las num Saco de Papel - "Brown Bag" nos EUA). Marque um encontro no meio do dia e combine de cada um levar sua própria refeição. Vocês poderão também trocar comidas (como faziam nos tempos de escola, onde cada criança levava sua lancheira). Tudo isso tornará o ambiente propício e descontraído para falarem sobre sua nova ideia.

Apesar de alguns adorarem o horário de almoço para essa finalidade, outros vêm o momento como uma pausa do trabalho e ficarão irritados se você falar de trabalho durante a refeição. Para essas pessoas, você precisa arranjar outros eventos.

\subsubsection{Inclua Comida (Do Food)}

Transforme uma reunião normal em um evento incluindo comida (Figura 2.4). Desde os tempos antigos as pessoas já entendiam a importância de dividir o pão. Deixe comida dis-

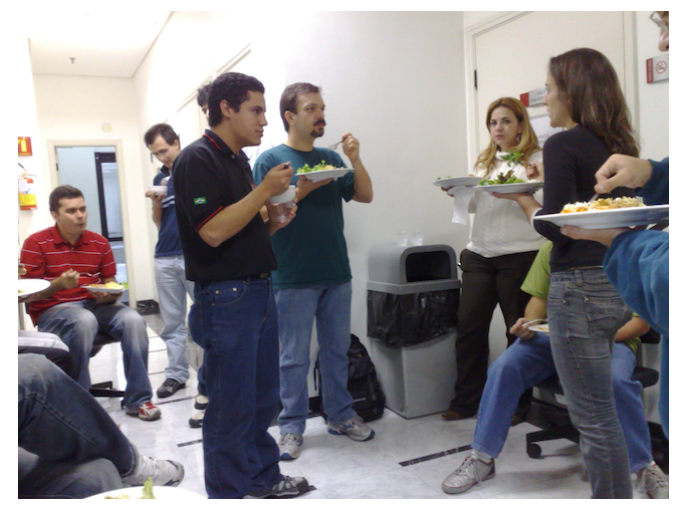
ponível nos encontros. Peça ajuda à empresa

Figura 2.4: Evento técnico: todos almoçando juntos, com a comida oferecida pela empresa 
para fornecer comida. Se eles não puderem ajudar, compre alguns biscoitos baratos com seu próprio dinheiro. As pessoas darão importância às suas palavras quando souberem que você tirou do próprio bolso para incrementar a reunião com comida.

Lembre-se das questões culturais que envolvem a comida. Cada empresa trata comida de maneira diferente durante o dia de trabalho. Seja sensível às questões de saúde (algumas pessoas são vegetarianas, por exemplo). Pessoas com problema de peso podem não gostar de ver os outros comendo biscoitos. Pessoas alérgicas à comida que você oferece podem se sentir excluídas. Tente sempre oferecer uma variedade de opções.

Comida é importante até em pequenos encontros, mesmo entre duas pessoas. Esse padrão transforma reuniões comuns em verdadeiros eventos. Todo mundo gosta de comida de graça. Porém, se você sempre trouxer comida às reuniões, as pessoas "mal-acostumadas" podem ficar irritadas quando a comida não aparecer. Quando a verba da comida estiver curta, use o Saco de Papel ${ }^{15}$.

\subsubsection{A Hora Certa (The Right Time)}

O melhor horário para uma entrevista é o último ou o penúltimo horário do dia, uma vez que esses são os horários que mais ficam na memória do entrevistador.

Leve o tempo em consideração quando agendar reuniões ou pedir ajuda aos outros. A pressão de um horário para acabar faz com que as pessoas foquem no assunto para poder terminar a tarefa estipulada para aquele horário. Evite horários em que as pessoas estão normalmente ocupadas. Marque eventos fora desses horários.

O tempo é um personagem que deve ser visto com a devida atenção. Nas primeiras páginas de A Preparação do Ator [Sta06], Stanislavski surpreende o leitor narrando uma situação que mostra a importância do cumprimento de horários estabelecidos: um novo grupo de teatro tem o seu primeiro encontro marcado; nessa primeira reunião, um dos membros do grupo que chegara poucos minutos atrasado disse ao grupo "Parece que estou um pouquinho atrasado". Ao ouvir essa displicente observação o diretor retruca:

"Aqui ficamos nós, sentados, à espera, enervados, irritados e 'parece que estou um pouquinho atrasado'. Nós todos chegamos aqui cheios de entusiasmo pelo trabalho que nos aguardava e agora, graças as senhor, todo esse ânimo destruiu-se. É difícil despertar a vontade criadora. Matá-la é facílimo. Quando interfiro no meu próprio trabalho, isso é comigo, mas que direito tenho eu de atrasar o trabalho de uma equipe inteira?"

O diretor obrigou o aluno a pedir desculpas a todos e deu a aula por encerrada, dizendo que

\footnotetext{
${ }^{15}$ Vide Seção 2.4.2.
} 
o primeiro ensaio é um acontecimento na vida do artista e que dele deve-se guardar a melhor impressão possível.

Todas as pessoas têm seus compromissos e agendas ocupadas. Se um grupo estabelece de comum acordo um horário para uma reunião, esse horário deve ser respeitado por todos os membros do grupo. O respeito pelos compromissos dos outros gera uma união muito grande entre os membros de uma equipe. O tempo é algo muito precioso. Quando ele é respeitado, as pessoas valorizam mais o trabalho e tornam-se naturalmente mais abertas e colaborativas.

Para alguns tipos de eventos, não há necessidade de se agendar horários. Grupos de Estudos ${ }^{16}$ normalmente acontecem em horários regulares e as pessoas são livres para comparecerem ou não dependendo de suas disponibilidades.

\subsubsection{Plante as Sementes (Plant The Seeds)}

Para espalhar o interesse, carregue materiais (sementes) e mostre-os (plante) quando surgirem oportunidades. Para enfatizar a importância de um material, faça cópias ao invés de só enviar a URL. Mostre, quando puder, artigos escritos por você, para aumentar sua credibilidade, ainda mais se tiverem sido publicados em veículos conhecidos e confiáveis.

Além de fornecer materiais, mostre-se disponível para esclarecer dúvidas. Isso irá garantir que coisas importantes, como seus livros, não irão desaparecer.

Não são todas as pessoas que se interessam por livros e leituras. Não fique desapontado. Essas pessoas podem ser justamente as pessoas chaves como Conectores ${ }^{17}$, Os que Adotam Cedo ${ }^{18}$ ou um Guru ao Seu Lado ${ }^{19}$. Carregar livros em aviões pode ser um problema. Se você mostra muitos livros pode correr o risco de alguém pegar emprestado e não devolver. Certifique-se de que os seus materiais de valor estão claramente identificados com o seu nome.

\subsubsection{Validação Externa (External Validation)}

Para aumentar a credibilidade da sua nova ideia, traga fontes de informação de fora da empresa. Antes de aceitar uma nova ideia, as pessoas querem ter certeza de que ela já teve sucesso fora da organização. Elas querem a garantia de que não é uma ideia impraticável de uma minoria da empresa. Fontes de mídia em massa (livros, artigos, periódicos, páginas na Internet, jornais) são um bom começo. As publicações externas costumam ter mais credibilidade do que as internas.

Esse padrão gera uma validação para a nova ideia na organização. Ele mostra que a inovação não é um fenômeno local. Mas você deve tomar cuidado para não exagerar. As pessoas não vão

\footnotetext{
${ }^{16}$ Vide Seção 2.5.3.

${ }^{17}$ Vide Seção 2.3.1.

${ }^{18}$ Vide Seção 2.1.2.

${ }^{19}$ Vide Seção 2.3.2.
} 
disponibilizar todo tempo do mundo para lerem livros e artigos durante o trabalho. Mostre-se disponível para responder a dúvidas e ouvir sugestões.

\subsubsection{Próximos Passos (Next Steps)}

No final de uma reunião sobre sua nova ideia, reserve um tempo para dizer aos participantes o que eles devem fazer em seguida, quais são os próximos passos. Depois de um longo dia de treinamento, os participantes podem ter dúvidas de como colocar em prática aquilo que eles acabaram de aprender. Ouvir e aprender algo é diferente de aplicar. Faça um brain storm para discutir com os participantes como aplicar a nova ideia.

Esse padrão permite que as pessoas aumentem o seu conhecimento sobre a inovação, se envolvendo em introduzi-la na empresa. Faça as pessoas criarem um plano de ação: onde a ideia pode ser posta em prática dentro da empresa? Como aprender mais sobre o assunto? Como fazer para difundir a ideia? Criar um Fórum Eletrônico ${ }^{20}$ ? Começar um Grupo de Estudos ${ }^{21}$ ?

Se você for de fora da empresa e tiver sido convidado para introduzir a ideia, evite falar o que os empregados devem fazer. Faça sugestões somente se for solicitado.

\subsubsection{Manter Contato (Stay in Touch)}

Tendo a lista das pessoas que te ajudam, não se esqueça delas e certifique-se de que não se esqueçam de você. As pessoas chaves para te ajudar tem muitos afazeres e acabam esquecendo a sua nova ideia. Encontre meios pró-ativos de manter sua mensagem presente no dia-a-dia das pessoas. Afinal, não é porque alguém decide adotar a nova ideia que essa pessoa não pode mudar de opinião. Mantenha contato com as pessoas chaves.

Fale com o gerente mesmo que você não queira nada. As pessoas cometem o erro de ir falar com o gerente só quando precisam de ajuda. Como resultado, o gerente fica com a impressão de que toda vez que você vai falar com ele é porque precisa de alguma coisa. Se precisar de uma maneira mais formal de manter contato, elabore um relatório periódico sobre o estado do seu progresso.

Esse padrão permite estabelecer ligações mais sólidas com os ajudantes chaves. Mas isso dá trabalho. Se não conseguir atingir diretores do alto escalão, peça ajuda aos Conectores ${ }^{22}$ ou ao seu Patrocinador Local ${ }^{23}$.

\footnotetext{
${ }^{20}$ Vide Seção 2.4.9.

${ }^{21}$ Vide Seção 2.5.3.

${ }^{22}$ Vide Seção 2.3.1.

${ }^{23}$ Vide Seção 2.7.2.
} 


\subsubsection{Fórum Eletrônico}

Crie um boletim eletrônico, uma lista de distribuição ou um sítio de Internet com possibilidade de edição para aqueles que desejam saber mais. Você precisa começar a manter maior contato com as pessoas interessadas em sua ideia. Falar com todas as pessoas todos os dias é muito difícil. Elas (e você) estão sempre cheios de tarefas.

Mantenha um fórum eletrônico público que contenha material sobre a inovação. Avise as pessoas da sua existência e atualize-o sempre que possível com informações sobre o seu progresso. Essa é uma maneira de Manter Contato ${ }^{24}$, mas não deve ser a única. A comunidade virtual o ajudará a manter a comunidade real, mas não sobrecarregue o fórum, pois ele poderá ser visto como spam. Conheça a sua comunidade e saiba o que ela deseja conhecer mais.

\subsubsection{Identidade do Grupo (Group Identity)}

Dê ao seu esforço pela mudança uma identidade, para que as pessoas reconheçam que ele existe. É mais difícil introduzir uma ideia quando as pessoas não percebem que existe um esforço. Uma maneira de começar é dar um nome ao grupo. Esse nome pode ser criado pelo próprio grupo. Use o nome frequentemente e em todo lugar que puder. Uma página na Internet e um endereço de email faz o grupo parecer oficial.

Esse padrão estabelece uma identidade para seus esforços e sua nova ideia. Essa identidade tornará sua iniciativa mais visível na empresa. Mas quando você etiqueta algo, as pessoas podem etiquetar você. Se elas virem o grupo como exclusivo, podem surgir preconceitos. Seja claro sobre os propósitos do grupo e Envolva Todos ${ }^{25}$.

\subsection{Em Ação}

Você já possui um grupo de seguidores e está pronto para agir. Os próximos padrões são para suas próximas ações. Eles mostrarão a importância do aprendizado constante e como trabalhar para estar sempre aprendendo, aumentando seus conhecimentos no assunto da inovação.

\subsubsection{Simplesmente Faça (Just Do It)}

Linda recebeu um email de um velho amigo. Ele sabe que ela escreveu três livros e está trabalhando no próximo. Ele está pensando em escrever um também, então ele pediu a ela um conselho. Eles trocaram alguns emails. Ele perguntou sobre o formato da proposta E se ele deve ter a maior

\footnotetext{
${ }^{24}$ Vide Seção 2.4.8.

${ }^{25}$ Vide Seção 2.10.1.
} 
parte do livro já escrito antes de apresentá-lo à editora $E$ se o assunto é muito abrangente ou se ele deve focar numa parte específica E... No final Linda disse: "Brad, eu tenho uma ótimo padrão que você deveria pensar em aplicar neste momento da sua aventura de escrever. Esse padrão é Simplesmente Faça."

Você não tem nenhuma experiência pessoal com a inovação, apenas acredita que ela seja uma boa ideia que pode ajudar a organização, mas não tem absoluta certeza. Para se preparar para espalhar a ideia, comece usando-a em seu próprio trabalho. Esse padrão irá gerar o conhecimento necessário para prosseguir como Evangelista ${ }^{26}$.

Gandhi disse: "Só os idiotas esperam a perfeição. O sábio procura o aprendizado". Então, o que fazer para aprender? A resposta está neste padrão: Simplesmente Faça.

\subsubsection{Mentor (Mentor)}

Quando quiser começar um projeto com a nova ideia, tenha por perto alguém que a entenda e que possa ajudar. Mesmo que as pessoas queiram usar a nova ideia, elas normalmente não sabem como. Elas precisam de alguém que oriente e garanta que os passos estão sendo dados corretamente. Encontre um consultor ou mentor, interno ou externo, para cuidar do grupo quando os membros estiverem começando com a nova ideia.

Escolha com cuidado quem será o Mentor. Procure uma pessoa com experiência, que conheça os problemas do time e que possa se adequar à cultura da empresa. Não permita, porém, que o time se torne dependente do Mentor. Você deve estipular o tempo em que esse Mentor estará disponível.

Esse padrão permite que as pessoas adotem a inovação de maneira correta. A mudança fica mais fácil com uma pessoa experiente compondo o time. Porém, nem sempre é fácil encontrar um Mentor. O número de pessoas experientes é sempre menor do que a quantidade de projetos.

\subsubsection{Grupo de Estudos (Study Group)}

Forme um pequeno grupo de pessoas que está interessado em um aprendizado contínuo sobre um determinado tópico. O grupo não deve ter mais do que oito ou dez pessoas e deve realizar reuniões semanais durante uma ou duas horas no máximo. Durante as reuniões, as pessoas devem ser livres para escolherem os assuntos a serem discutidos e darem sua própria opinião.

${ }^{26}$ Vide Seção 2.2.1. 


\section{Experiência pessoal sobre grupo de estudos}

Durante vários meses do ano de 2007 e começo de 2008, montamos em nossa empresa um grupo de estudos. Inicialmente, fizemos um convite formal a todas as pessoas da área de tecnologia para participar do grupo. As primeiras reuniões tiveram uma participação de, em média, seis a oito pessoas. Durante os meses seguintes várias pessoas passaram pelo grupo, participando de um ou dois encontros. Mas, no final, o grupo se caracterizou pela presença de quatro a cinco pessoas fiéis ao estudo.

Nas reuniões, foram discutidos vários assuntos técnicos, conceitos de programação orientada a objetos, padrões de projeto, metodologias ágeis e outros assuntos relacionados ao desenvolvimento de software. Além desses assuntos, também foram abordados temas relacionados ao clima organizacional. Em algumas reuniões foram discutidas as questões culturais da empresa, vantagens e desvantagens de determinadas políticas. Os membros do grupo concordavam que a empresa estava passando por transformações importantes no âmbito cultural. A adoção de uma metodologia de desenvolvimento de software se fazia imprescindível naquele momento.

As Metodologias Ágeis foram consideradas pelo grupo adequadas à realidade da empresa. Foi feita uma tentativa de apresentar à direção a metodologia. A reunião foi feita dois meses depois da primeira tentativa, depois de vários adiamentos. Este fato por si só serviu para nos alertar do quanto seria trabalhosa qualquer tentativa de mudança.

O grupo de estudos continuou ativo em suas reuniões. Por conter participantes de equipes distintas do grupo de tecnologia, pessoas com visões e vivências diferentes, o grupo sempre teve discussões muito ricas. Observou-se claramente que cada assunto estudado não ficava limitado às paredes da sala de reunião, mas que perduravam durante o resto da semana por toda empresa. Alguns estudos podiam ser imediatamente aplicados na prática. Outros, mais subjetivos, ecoavam inconscientemente pelos corredores da empresa.

\subsection{Tudo São Pessoas}

Ao longo de todo processo de mudança, a cada pequeno passo de seu caminho, você encontrará pessoas. Isso significa comunicação. As pessoas querem saber onde elas se encaixam, elas querem 
fazer parte. Os padrões desta seção o ajudarão a interagir com indivíduos e organizações. Você verá também para onde correr quando as coisas estiverem difíceis.

\subsubsection{Toque Pessoal (Personal Touch)}

Para convencer as pessoas de que sua ideia é valiosa, mostre como ela pode ser útil particularmente para elas. As empresas e as pessoas são diferentes umas das outras. Não podemos esperar que elas vejam as coisas da mesma maneira que nós, nem que algo que funcionou em um lugar funcione perfeitamente em outro. Mesmo que sua ideia seja aceita, os velhos hábitos dos indivíduos não vão desaparecer sem que se faça bastante esforço.

Tire um tempo para estudar as necessidades das pessoas antes de falar com elas. Tenha em mente que o seu trabalho não é mudar pessoas, mas ajudá-las a ser mais ainda o que elas já são. Mas não tente falar com todo mundo. Reconheça que você não tem o poder de convencer todos. Quando alguém não quiser lhe ouvir, encontre um Construtor de Pontes ${ }^{27}$.

\subsubsection{Terno de Alfaiate (Tailor Made)}

Um conselho muito ouvido é "não venda a tecnologia, venda a solução de negócio". Mesmo que sua nova ideia seja maravilhosa, ela não significará nada se você não mostrar o que a empresa ganhará com esta ideia. Mostre como a sua inovação se encaixa perfeitamente nas necessidades da empresa. A sua inovação não será somente uma boa ideia, mas algo que permitirá à empresa melhorar suas práticas atuais.

Seja o mais claro possível sobre as motivações para a mudança. O que parece óbvio para você não necessariamente é para os outros. Esse padrão exigirá um esforço para ser aplicado. Ao invés de usar soluções prontas, você terá que pesquisar. Você precisará de tempo para estudar a empresa e entender suas necessidades, para então casar as suas ideias com essas necessidades.

\subsubsection{Ombro para Chorar (Shoulder to Cry On)}

Para não desanimar, encontre oportunidades para falar com pessoas que têm o mesmo objetivo que você. Você pode se sentir sufocado ao tentar introduzir uma nova ideia e perder a coragem. As vezes, você só quer sentir que não é o único que lida como essas questões. Não se sentir sozinho por si só já é importante. Forme um grupo e pense em grupo para resolver questões que isoladamente você não consegue.

Dê a todos a chance de "chorar" e de "oferecer um ombro para chorar". Se você não puder formar esse grupo, use um padrão escrito por Charles Weir e James Noble, que recomenda: quando

${ }^{27}$ Vide Seção 2.11.1. 
você não consegue encontrar a solução de um problema, explique ele bem alto para alguém ou alguma coisa. Isso ajuda você a entender melhor o problema. Eles dizem que isso funciona até com seu cachorro.

\subsection{Um Novo Papel: Agora Você é Dedicado!}

A boa notícia é que você está evoluindo no seu trabalho. A má notícia é que você ainda tem muito a fazer. Os próximos padrões farão você dar um enorme passo: fazer com que o esforço de mudança faça parte do seu dia-a-dia.

\subsubsection{Defensor Dedicado (Dedicated Champion)}

Para aumentar a eficácia da introdução da nova ideia, faça com que essa tarefa esteja na definição do que é o seu trabalho. Introduzir uma nova ideia em uma corporação é muito trabalho para um voluntário. Você não é um voluntário. Introduzir essa ideia faz parte do seu trabalho. A ideia se perderá sem um esforço pró-ativo de alguém cuja responsabilidade é trazer essa inovação.

Para convencer os gerentes, apresente números: quantas pessoas estão interessadas, quais os casos de sucesso. O apoio de um Guru ${ }^{28}$ que o gerente confie ou uma Validação Externa ${ }^{29}$ pode lhe ajudar a obter aprovação da gerência. Você é "dedicado" se tiver devoção à causa e tempo alocado para a tarefa de vencer com a inovação.

Esse padrão determina um papel bem definido para a pessoa responsável por implantar a nova ideia. Essa definição gera uma expectativa de sucesso. Justifique o seu trabalho com números, métricas. Contabilize inclusive os pequenos sucessos.

\subsubsection{Patrocinador Local (Local Sponsor)}

Peça ajuda ao "alto-escalão" da empresa. A sua eficiência aumenta consideravelmente quando o seu chefe apoia o que você faz. Você precisa de atenção e recursos para a nova ideia. Convença os gerentes que a ideia cabe perfeitamente na realidade da empresa, que ela foi Feita Sob Medida ${ }^{30}$.

Tente fazer com que o patrocínio não venha de uma única pessoa. Tente ganhar confiança de pessoas que tem poder de adotar a inovação para os projetos da empresa. Com esse padrão você tem condições de se tornar um Defensor Dedicado ${ }^{31}$. Porém, trazer um patrocinador errado pode fazer você perder o foco, ou, ainda pior, uma pessoa muito poderosa pode roubar sua ideia e levar os créditos. Procure uma pessoa respeitada, que vai ajudar, não ferir, suas boas intenções.

\footnotetext{
${ }^{28}$ Vide Seção 2.3.2.

${ }^{29}$ Vide Seção 2.4.6.

${ }^{30}$ Vide Seção 2.6.2.

${ }^{31}$ Vide Seção 2.7.1.
} 


\subsubsection{Anjo Corporativo (Corporate Angel)}

Ao introduzir uma nova ideia, conheça os objetivos e metas da corporação e tente alinhar sua ideia com esses objetivos. Para isso, peça ajuda a algum executivo importante. Tente saber dele quais os recursos disponíveis. Ele pode fornecer dados importantes, como disponibilidade de verbas, pessoas, espaços físicos, equipamentos, etc. Um alto executivo interessado na sua ideia pode disponibilizar recursos e direcionar a implantação da nova ideia.

\subsection{Convencendo as Massas}

Mesmo que sua ideia seja boa e aceita por Os que Adotam Cedo ${ }^{32}$, você precisa de ferramentas para conseguir convencer a Massa. Esta seção mostrará padrões que podem ser usados para mostrar às pessoas que mudanças são boas.

\subsubsection{Rodada de Testes}

Quando a empresa não estiver aberta a aceitar a nova ideia, sugira que seja feita uma experiência por pouco tempo para que eles possam avaliar os resultados. Na empresa, poderá existir pessoas que são categoricamente contra a sua ideia. Você nunca conseguirá implantar a inovação sem antes mostrar que ela pode funcionar pelo menos uma ou duas vezes. Se a inovação for experimentada por um pequeno grupo, por algumas semanas ou meses, e os resultados forem satisfatórios, você poderá usar este caso como exemplo de sucesso para espalhar a ideia pelo resto da corporação.

As pessoas tem maior facilidade de aceitar uma mudança se ela não for imposta como algo definitivo. Assim, se a ideia falhar, esse fato será encarado como um aprendizado, não como um erro. A Rodada de Testes ajudará potenciais usuários a compreenderem melhor a sua ideia. Você ficará em uma posição de maior visibilidade para um possível Patrocinador Local ${ }^{33}$. Se sua ideia for realmente boa, ela se venderá sozinha. Se não for, será encarada como um "teste" e cairá no esquecimento.

Esse padrão pode ser visto como o uso de um protótipo. Ao invés de gastar toda sua energia e seus recursos de uma só vez na implantação de uma ideia, faça isso numa escala menor. As consequências negativas terão proporções irrisórias. Os resultados positivos, por sua vez, indicarão que você poderá "aumentar a dose" rumo ao sucesso.

\footnotetext{
${ }^{32}$ Vide Seção 2.1.2.

${ }^{33}$ Vide Seção 2.7.2.
} 


\subsubsection{Revisão do Guru (Guru Review)}

Peça aos Gurus ao Seu Lado ${ }^{34}$ fazerem uma avaliação formal da sua ideia e apresentá-la aos gerentes. Alguns gerentes e diretores são mais abertos, mas outros relutam em mudar até que tenham certeza de que é uma ideia consagrada e aceita. Eles estão cansados de ouvir promessas de "balas de prata" e tornaram-se céticos. Mas, ao mesmo tempo, eles estão sempre interessados em ideias que tornarão seu trabalho mais fácil e eficiente. Eles só precisam de evidências de que a ideia é boa. Os líderes confiarão no julgamento do guru, principalmente se for uma pessoa de muitos anos de convivência.

Esse padrão produz dados sobre a inovação vindo de pessoas de "primeira-linha". Porém o seu uso pode ser arriscado. Se o relatório dos gurus não for positivo, ou tiver poucos gurus a favor, certamente sua ideia não vingará.

\subsubsection{Grande Personalidade (Big Jolt)}

Para dar maior visibilidade às suas ideias, convide uma pessoa importante de fora para falar sobre a ideia na empresa. A sua ideia é muito nova para as pessoas. Elas têm medo de aceitá-la sem ter dados mais confiáveis, sem conhecer alguém que já tenha passado pela mesma experiência e obtido sucesso. Você pode trazer um professor universitário respeitado, um líder de uma grande corporação, ou um renomado consultor internacional. Esta pessoa pode apresentar o próprio ponto de vista sobre a ideia que você está introduzindo.

\footnotetext{
${ }^{34}$ Vide Seção 2.3.2.
} 


\section{O especialista em produtos}

Já fazia um bom tempo que estávamos promovendo um Grupo de Estu$\operatorname{dos}^{35}$ e tivemos várias reuniões sobre Métodos Ágeis. Eu já havia feito duas apresentações para a diretoria da empresa sobre Programação Extrema, mas nenhuma delas resultou em qualquer tipo de iniciativa de adoção das práticas ágeis. Até aquele momento, apenas a equipe na qual eu trabalhava fazia XP, de forma independente.

A diretoria quis promover, na época, um curso sobre produtos para algumas pessoas chaves na área de tecnologia. A ideia foi trazer um consultor renomado para falar sobre produtos de sucesso na Internet. Esse consultor foi um dos grandes nomes no eBay (www.ebay.com), o maior portal de vendas e leilões online do mundo. $\mathrm{O}$ foco principal do treinamento estava mais ligado a interfaces, usabilidade, apresentação. Todos os assuntos abordados falavam do usuário dos sistemas. A conclusão era de que deveríamos dedicar cada minuto do nosso trabalho ao nosso usuário, à experiência dele. Foi-nos apresentado o livro Não Me Faça Pensar [Kru06], um dos livros mais vendidos sobre esse assunto (usuário). O livro trata principalmente de questões humanas e psicológicas relacionadas com o uso de sistemas na Internet.

Uma grande parte dos presentes no curso era de uma área bem técnica. Poucos tinham experiência em lidar com o lado humano dos sistemas que desenvolviam. O que o consultor estava tentando dizer era que a parte mais importante no desenvolvimento de um software é justamente a pessoa que está lá do outro lado usando o software. Já que o usuário é o mais importante, precisaríamos aprender a conhecê-lo, a entender suas vontades. Precisaríamos trabalhar olhando para pessoas mais do que para máquinas.

O ponto chave do treinamento foi quando falou-se de Métodos Ágeis. Alguns presentes já sabiam há tempos que a equipe na qual eu trabalhava usava uma metodologia diferente. Mesmo assim, quando o consultor falou sobre métodos ágeis, tudo parecia uma grande novidade. Varias perguntas surgiram. O assunto tornou-se polêmico, mas ao mesmo tempo muito interessante. O consultor ressaltou de forma enfática que gostava muito dessas metodologias.

Pouco tempo após esse episódio, o diretor veio falar comigo, me perguntando se eu conhecia o livro Extreme Programming Explained [Bec99]. Ele me disse que estava lendo e que estava achando muito interessante. Poucos dias depois, pediu para prepararmos um curso sobre Métodos Ágeis para toda a área de tecnologia da empresa. 


\subsubsection{Audiência Real (Royal Audience)}

Organize para os gerentes e membros da companhia um encontro com uma Grande Personalidade $^{36}$. Não limite a visita de alguém famoso à uma apresentação para um grupo pessoas. Faça com que os líderes encontrem a Personalidade numa reunião particular. Use os intervalos das apresentações, ou os horários de almoço, para tornar o visitante disponível para os membros importantes da empresa. Organize almoços (ou jantares, neste caso com o número de pessoas limitado) com a Grande Personalidade. Tenha certeza de que o visitante concorda em falar mais sobre o assunto nesses momentos "livres".

Não espere que todos aceitem o convite. Apenas ofereça a oportunidade. Para os que não puderem comparecer, o convite já é por si só importante. Esse padrão permite que as pessoas apreciem um momento mais próximo com alguém importante. Tome cuidado para não ter o efeito contrário: se você quiser fazer um encontro pequeno, as pessoas que não forem convidadas podem sentir-se excluídas. Mas se você tiver o costume de Envolver Todos ${ }^{37}$, as pessoas aceitarão não serem convidadas, já que sabem que serão incluídas num próximo evento.

\subsection{Estratégias para Influenciar}

Com os vários padrões apresentados anteriormente, você já possui recursos suficientes para iniciar o seu trabalho. Mas você pode expandir ainda mais seu leque de estratégias. Nesta seção, são mostrados mais alguns padrões que o ajudarão a influenciar pessoas.

\subsubsection{Histórias para Contar (Hometown Story)}

Para ajudar as pessoas a compreenderem a utilidade da sua ideia, encoraje aqueles que já tiveram sucesso com essa ideia a contarem suas histórias. Ter a experiência por si só é a melhor coisa, mas ouvir a experiência dos outros é a segunda melhor coisa! Tente fazer com que as pessoas contem suas experiências de sucesso de maneira informal e interativa. Inclua Comida ${ }^{38}$ e promova um Fórum Eletrônico ${ }^{39}$ para tornar o ambiente mais descontraído. Permita que as pessoas perguntem livremente sobre as experiências de sucesso, que obtenham toda informação que desejam para tirarem suas próprias conclusões.

Tome cuidado ao escolher a pessoa que vai contar as histórias. Não escolha pessoas arrogantes, que contarão a história mostrando somente a sua própria participação no sucesso. Traga pessoas

\footnotetext{
${ }^{36}$ Vide Seção 2.8.3.

${ }^{37}$ Vide Seção 2.10.1.

${ }^{38}$ Vide Seção 2.4.3.

${ }^{39}$ Vide Seção 2.4.9.
} 
queridas e respeitadas. Você pode também tentar criar um evento onde várias pessoas podem contar suas experiências.

\subsubsection{O Cheiro do Sucesso (Smell of Success)}

Ele é invisivel e intocável, mas desperta uma das mais poderosas reações humanas quando agrada ou desagrada as pessoas. É o mais sutil e subjetivo dos sentidos: o cheiro.

Quando o resultado de seus esforços começarem a aparecer, as pessoas certamente virão falar com você. Aproveite esse momento para ensiná-las. Administre bem as expectativas das pessoas que sentirem o Cheiro do Sucesso, esclarecendo o que já foi feito e o que ainda precisa ser trabalhado. Esse padrão permite que você use o seu próprio sucesso para gerar ainda mais sucesso.

\subsubsection{O Suficiente (Just Enough)}

Conceitos novos e complicados podem sobrecarregar os novatos. Saiba introduzir a inovação aos poucos, para não cansar as pessoas. Faça apenas uma introdução sobre o assunto e deixe um material com maiores detalhes disponível. Toda nova ideia tem uma curva de aprendizado. Não ultrapasse o limite de absorção dos alunos. Não basta entender a ideia, mas assimilar seus conceitos mais profundos, e isso requer tempo. Você pode desestimular as pessoas se tornar o assunto complicado.

Se for fazer uma apresentação, concentre-se no fundamental. Inclua apenas um ou dois slides sobre conceitos mais difíceis. Em momentos informais só fale sobre informações que as pessoas possam "aguentar", acrescentando que ainda há muito mais para se aprender. Depois que os aprendizes tiveram tempo de absorver o básico, encontre oportunidades para avançar com os conceitos mais complexos.

Quando estávamos implantando Métodos Ágeis na nossa empresa, algo que nos ajudou muito foi quando distribuímos algumas cópias de um livro bem pequeno, mas com várias ilustrações simples de situações comuns em times que adotam XP e Scrum [Kni07]. Apesar do livro não trazer com detalhes todas as particularidades dessas metodologias, ele continha O Suficiente para aquele momento.

Com esse padrão você obterá uma lenta, porém garantida, compreensão da inovação. Porém, o que funciona com algumas pessoas pode não funcionar com outras. Algumas pessoas podem achar que você não as considera suficientemente inteligentes. Tente manter uma linha mediana, entre os mais "espertos" e os que precisam de um tempo maior para aprender. 


\subsubsection{No Seu Espaço (In Your Space)}

Mantenha a nova ideia visível espalhando lembretes por toda organização. O espaço de trabalho é um lugar extremamente comunicativo. Cartazes, post-its, imagens, gráficos, tudo vale. Se as pessoas não forem lembradas, elas se esquecem da sua ideia. Elementos informativos no espaço de trabalho são imagens que ficarão gravadas nas mentes das pessoas e, consequentemente, na "mente coletiva" da organização.

Um bom exemplo é um quadro branco (ou negro) para uso informal. Um local onde se possa rabiscar livremente ideias. As pessoas que passarem em frente a esses "rabiscos" serão inconscientemente influenciadas por eles. Se suas ideias de inovação estiverem desenhadas num quadro que é visto por pessoas que passam, elas terão grande impacto na mente dessas pessoas.

Equipes de Desenvolvimento Ágil utilizam muito este padrão (Figuras 2.5 e 2.6). O quadro branco é usado para várias finalidades: desenhar uma nova ideia de arquitetura do sistema; avisar o time sobre datas de entrega, horários de encontros; mostrar para o grupo de desenvolvedores e para o cliente o andamento da iteração atual; documentar implementações recentes; informar sobre boas práticas a serem seguidas (e práticas não tão boas, que devem ser evitadas); descontrair o time com piadas e desenhos de personagens; e qualquer outro tipo de informação visual que possa ser imaginada e criada.

\subsubsection{Brinquedinho (Token)}

Mantenha uma ideia de inovação viva na cabeça das pessoas presenteando-as com "brinquedinhos" que lembrem o tópico que você está introduzindo. Nosso cérebro não suporta muita coisa ao mesmo tempo. A informação de hoje é rapidamente substituída pela de amanhã. As pessoas precisam de lembretes. Sociólogos observam que em todas as culturas, mesmo um pequeno presente faz diferença. Amostras grátis são distribuídas em locais de compra porque provou-se que o retorno é muito maior do que o custo.

Alguns exemplos de "brinquedos": ímãs, xícaras, bótons, lápis, bloco de notas, bonequinhos mascotes. Mas tente não gastar muito. Encontre algo que seja econômico, mas ao mesmo tempo impressionante e eficaz. Não distribua muitos brinquedos, senão eles podem perder o valor. Deixe que alguns "cobicem" o brinquedo dos outros.

A maior dificuldade deste padrão é arranjar verba da empresa para comprar os brindes. Quando puder, use seu próprio dinheiro. Muitas vezes não é tão caro. As pessoas ficarão impressionadas quando souberem que você gastou do próprio bolso. Isso mostrará a elas o quanto você acredita na sua ideia. 


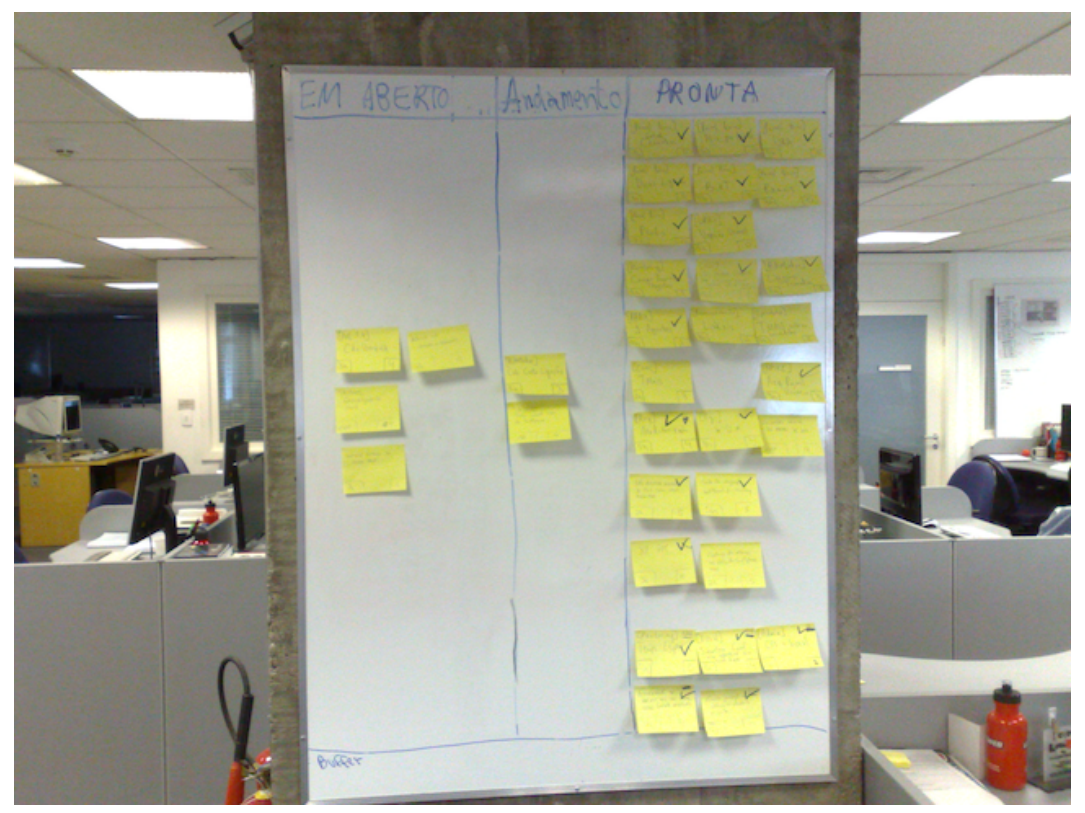

Figura 2.5: Quadro de histórias utilizado por uma equipe ágil

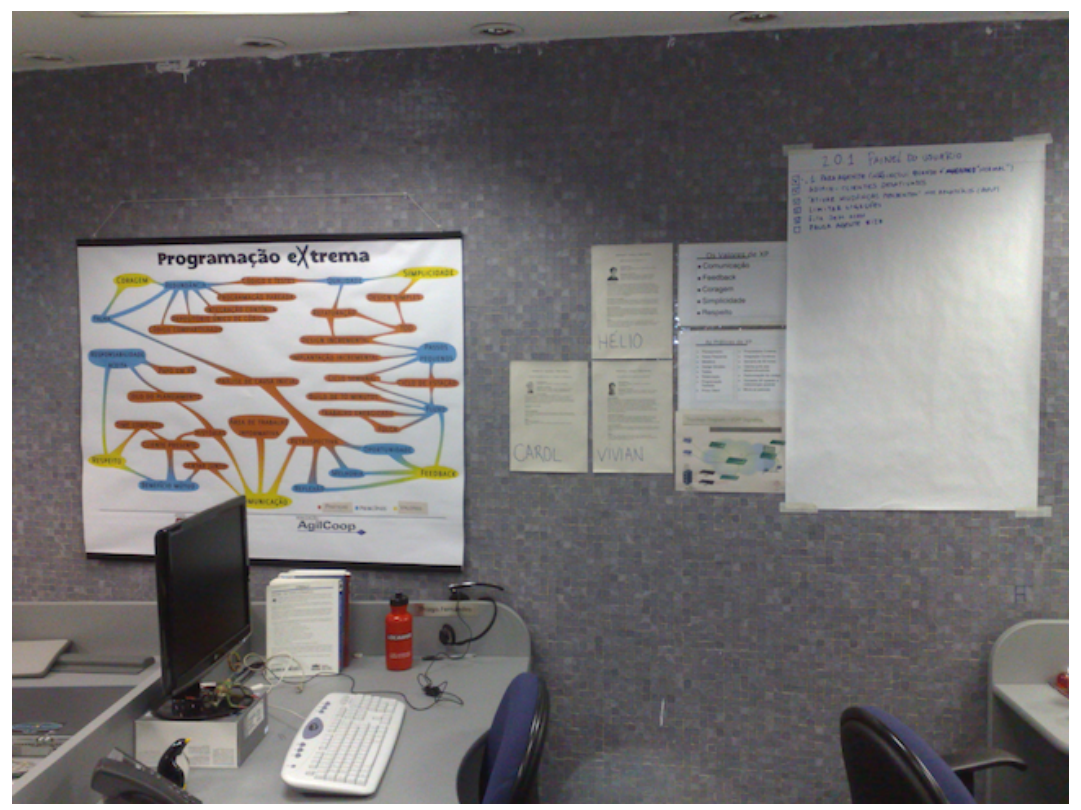

Figura 2.6: Área de trabalho informativa: dicas da metodologia 


\subsubsection{Local, Local, Local (Location, Location, Location)}

Para evitar interrupções que perturbem o fluxo de um evento, tente realizar eventos importantes fora da empresa. Quando você realiza um evento no local de trabalho das pessoas, elas tendem a se distrair facilmente com suas obrigações diárias. Apesar de parecer que o escritório da empresa seja o local mais conveniente para realizar treinamentos para conter custos, o maior custo para a empresa é o de um treinamento que não é absorvido ao máximo pelos participantes. Pode ser mais econômico reservar um centro de convenções e providenciar alimentação para as pessoas. Não corra o risco do participante não se concentrar devidamente no treinamento porque ficou dividido entre o evento e suas tarefas diárias.

Faça com que os participantes desliguem seus telefones celulares. O evento deve ser algo especial, desconectado das obrigações do escritório, um ambiente de liberdade que permita às pessoas exercerem sua criatividade. É claro que assuntos muito urgentes deverão ser tratados, mas conscientize as pessoas de que grande parte dos problemas poderão ser resolvidos no dia seguinte.

\subsection{Continue Caminhando}

Você já teve bastante sucesso com as mudanças. As pessoas estão usando a inovação. Mesmo aqueles que não usam, estão falando sobre ela. Os padrões desta seção lembram a importância de continuar caminhando. Mesmo uma boa ideia pode desaparecer se não estiver presente no dia-a-dia das pessoas.

\subsubsection{Envolva Todos (Involve Everyone)}

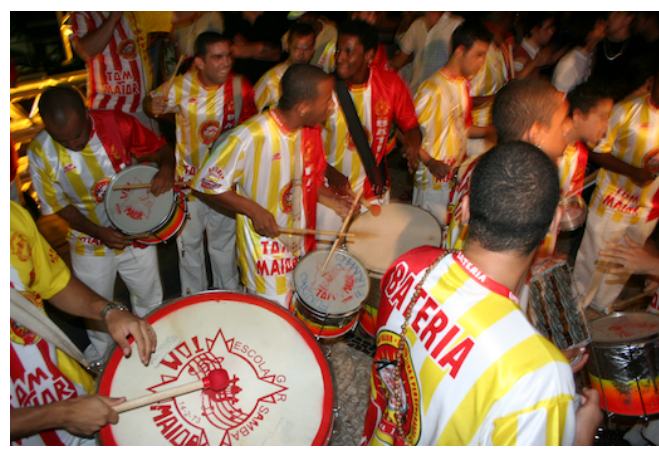

Figura 2.7: Habilidades individuais unidas num objetivo comum
Para que uma nova ideia tenha sucesso na empresa, todos devem ter a oportunidade de ajudar com pequenas contribuições individuais. As pessoas podem encarar a inovação como o "seu show". Tente mostrar que você não se importa de não receber os créditos pelo sucesso. Envolva o máximo de pessoas possível na sua ação. Faça com que elas se sintam importantes no grupo de Inovadores.

Liderar uma mudança não é um trabalho para uma única pessoa. Por causa da participação de um número grande de pessoas, a ideia passa a pertencer a toda a empresa e não 
só a uma única pessoa. As pessoas se apegam emocionalmente ao que elas criam. Os que participarem na implantação da mudança se sentirão donos da ideia. Envolva pessoas de todos os departamentos para que todos sintam-se co-autores da ideia.

Se você nomear alguém como líder, deve estar preparado para seguir as instruções. Prepare-se psicologicamente para ceder a posse da ideia de inovação para outra pessoa. Esse padrão ajuda a construir uma rede coesa de pessoas envolvidas com a mudança. Todos esses indivíduos sentirão que fazem parte da mudança e isso trará força para sua ideia. Eles o ajudarão a espalhar a ideia pelo resto da empresa.

Quando você envolve muita gente, pode abrir espaço para outros pontos de vistas, algumas vezes até contrários. Mas nem todos precisam concordar com tudo para começar a agir. As habilidades individuais unidas num objetivo comum dará força ao trabalho.

\subsubsection{Momento Sustentável (Sustained Momentum)}

Implantar uma ideia é como plantar uma árvore: sem água, sol e um pouco de carinho, a jovem árvore morrerá.

Tenha uma atitude pró-ativa no trabalho de sustentar o interesse pela nova ideia. Você terá muitas coisas que farão com que a tarefa de introduzir a nova ideia fique em segundo plano. Não permita que isso aconteça. Faça pequenas ações todos os dias, não importa o quão insignificantes elas possam ser. Isso ajudará você a manter a ideia viva. Além disso, um pequeno passo adiante significa um passo a menos de distância do objetivo final.

Vários padrões deste catálogo podem ser usados diariamente para ajudá-lo a manter o trabalho de mudança: Fórum Eletrônico ${ }^{40}$, Saco de Papel ${ }^{41}$, Grupo de Estudos ${ }^{42}$, Manter Contato ${ }^{43}$, Plante as Sementes $^{44}$, Diga Obrigado ${ }^{45}$ e vários outros.

\subsection{Lidando com Resistência}

Você irá se deparar com aqueles que não estão tão entusiasmados com a mudança quanto você. Algumas pessoas serão realmente difíceis, mas a maioria apenas hesitará um pouco. Normalmente, temos a tendência a evitar as pessoas que se opõem, mas o certo é aprender uma forma de usá-las a nosso favor. Os padrões desta seção ajudam a conquistar a confiança dos mais céticos.

\footnotetext{
${ }^{40}$ Vide Seção 2.4.9.

${ }^{41}$ Vide Seção 2.4.2.

${ }^{42}$ Vide Seção 2.5.3.

${ }^{43}$ Vide Seção 2.4.8.

${ }^{44}$ Vide Seção 2.4.5.

${ }^{45}$ Vide Seção 2.3.4.
} 


\subsubsection{Construtor de Pontes (Bridge-Builder)}

Forme pares entre as pessoas que aceitaram a nova ideia com pessoas que não. Mesmo que você seja muito convicto ao expor suas novas ideias, algumas pessoas não aceitam, simplesmente por não conhecerem ou não confiarem em você. Use então alguém que essas pessoas confiam e que já tenha aceitado a sua ideia. A opinião de alguém conhecido e confiável é muito poderosa, principalmente quando você está tentando convencer algum dos Retardatários ${ }^{46}$.

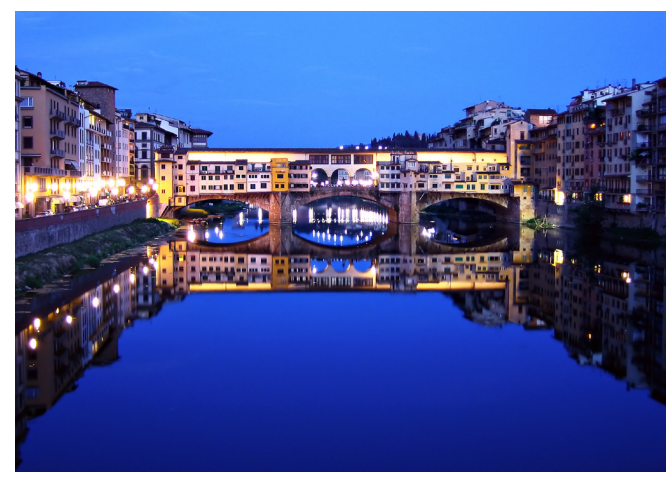

Figura 2.8: Ponte: o velho ligado ao novo

\subsubsection{O Cético Defensor (Champion Skeptic)}

Os líderes formadores de opinião são, às vezes, os mais resistentes à sua nova ideia. Peça a ajuda deles. Pergunte suas opiniões e use-as para aumentar seus esforços. Convide-os para todas as apresentações e, se eles não estiverem disponíveis, se ofereça para uma reunião particular. Eles servirão como "céticos oficiais". Convencê-los pode significar convencer a empresa inteira.

\subsubsection{Política de Corredor (Corridor Politics)}

Antes de levar uma ideia a votação, tente garantir que todas as pessoas envolvidas já estão convencidas dos benefícios da ideia. Dificilmente uma ideia nova recebe um voto de "SIM" na primeira vez em que é ouvida. Trabalhe informalmente com os tomadores de decisão. Tente obter a aprovação prévia de qualquer um que possa matar sua ideia. Ouça os contra-argumentos para a sua ideia antes de chegar numa reunião, tendo assim tempo para elaborar uma resposta convincente sobre eles.

Tente conhecer as verdadeiras preocupações das outras pessoas antes de expor suas ideias e estude uma forma de colocar a inovação como uma solução para as preocupações e não como mais uma preocupação.

\footnotetext{
${ }^{46}$ Vide Seção 2.1.3.
} 


\subsubsection{Sem Medo (Fear Less)}

Transforme a resistência à nova ideia em algo a seu favor. Toda inovação, no fundo, rompe com algo. Logo, a resistência é bem vinda. Precisamos da resistência para testar nossas ideias e convicções. Os céticos são um presente. Eles nos dão informações sobre o caminho que estamos seguindo e sobre como podemos adaptar nossa abordagem.

Talvez o ponto mais essencial da mudança é a nossa forma de lidar com o medo. Num processo de mudança existe medo de dois lados: quem está sendo mudado quer evitar a dor de ter que, talvez, perder algo; quem está promovendo a mudança tem medo de que sua ideia esteja errada. Quando esses dois lados entram em choque surge um impasse. A resistência não é a principal razão pela qual uma mudança falha. É a reação à resistência que causa problema.

Dificilmente se obterá $100 \%$ de aprovação a uma nova ideia. E isso é bem vindo. Conforme Nilton Bonder [Bon98]:

"Toda lei que não deixa em aberto a possibilidade de sua execução, justamente por sua desobediência, é uma arbitrariedade. Segundo o Tratado de Sanhedrin, em caso de julgamento de penas capitais - quando se faziam necessários 23 juízes -, caso houvesse uma unanimidade na condenação do réu, o julgamento era desqualificado e este liberado. O sentido de tal lei é a desconfiança de que um processo possa ser tão bem conduzido que não paire qualquer dúvida quanto a uma leitura diferente da situação."

É difícil ouvir quando não concordamos com algum ponto de vista. Normalmente, ficamos fixados em nosso ponto de vista. Uma outra abordagem seria encorajar a outra pessoa a falar mais sobre o ponto de vista dela. Só de ouvi-la já ajudará vocês a se entenderem.

Peça ajuda aos resistentes. Certifique-se de que eles sabem que você está ouvindo. Ouça de verdade e tente aprender com ele. Tente fazê-los entender que aceitar a nova ideia não significa jogar fora a experiência deles. Não assuma que a posição cética é fixa. Alguém que inicialmente parecia contra pode se virar a seu favor.

Esse padrão permite que você use a resistência a seu favor, ao invés de a usarem contra você. As pessoas que virem você lidar com os céticos de forma respeitosa vão admirá-lo por isso.

\subsubsection{Sussurre no Ouvido do General (Whisper in the General's Ear)}

Muitas vezes alguns gerentes são difíceis de serem convencidos quando estão no meio do grupo. Tente arranjar com ele um encontro privado para explicar seu ponto de vista. Os gerentes que são contra a sua ideia tem o poder de bloquear seu progresso. Explique para ele em particular quais são seus objetivos e como ele pode ser envolvido em tudo isso. 
Quando falar com ele, fale só $O$ Suficiente ${ }^{47}$ e considere até a possibilidade de dar crédito a ele caso a ideia dê certo. Só discorde se você tiver como demonstrar que ele se beneficiará com o outro ponto de vista. Se você não conseguir de forma alguma agendar uma reunião com o gerente, você pode caminhar com ele dá próxima vez que ele estiver indo para o café. Tenha já em mente um "discurso de elevador" de dois minutos. Acima de tudo, você precisará ter muita paciência no trabalho de trazer o gerente cético para o seu lado.

Esse padrão permite que você ganhe apoio da gerência para sua nova ideia e, ao mesmo tempo, mantém a dignidade do gerente preservada.

\subsection{Resumo dos Padrões para Introduzir Novas Ideias}

Segue uma tabela que resume os 48 padrões compilados por Linda Rising e Marry Linn Manns em seu livro [RM05]. Os padrões estão divididos em quatro categorias:

- Antes: devem usados para começar a introduzir uma ideia.

- Durante: devem ser usados enquanto a ideia estiver sendo disseminada.

- Depois: devem ser usados para que a ideia não se perca depois de implantada.

- Resistência: padrões específicos para lidar com a resistência.

Além da tabela de resumo, na Figura 2.9 trazemos o mapa mental dos padrões, agrupados pelas suas respectivas categorias. Os padrões assinalados com um sinal de "polegar positivo" são aqueles que, na nossa visão, foram os mais essenciais. Acreditamos que nossa ideia (introdução de Métodos Ágeis numa organização) só foi adotada porque usamos esses padrões. Aqueles que estão com o sinal de "sorriso" também foram muito usados e, apesar de terem exercido alguma influência, consideramos para eles um grau de importância menor.

\footnotetext{
${ }^{47}$ Vide Seção 2.9.3.
} 


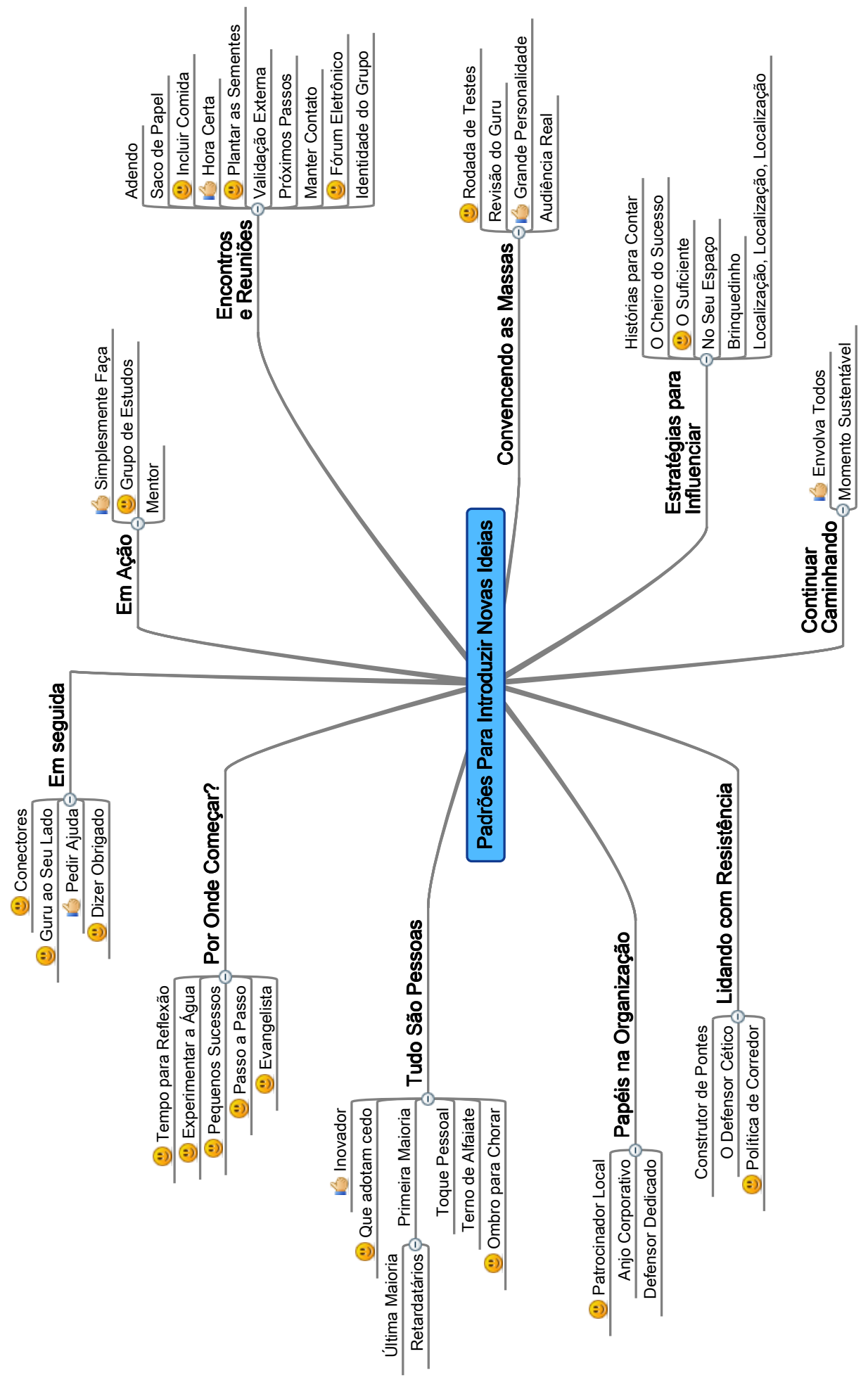




\begin{tabular}{|c|c|c|}
\hline Tema & Padrão & Resumo \\
\hline Antes & Peça Ajuda & $\begin{array}{l}\text { Uma vez que a tarefa de introduzir uma nova ideia numa orga- } \\
\text { nização é um trabalho grande, procure pessoas e recursos que pos- } \\
\text { sam ajudá-lo em seus esforços. }\end{array}$ \\
\hline Antes & Saco de Papel & $\begin{array}{l}\text { Use o horário de almoço como um momento convenientemente } \\
\text { relaxante para as pessoas ouvirem suas ideias. }\end{array}$ \\
\hline Antes & Conectores & $\begin{array}{l}\text { Procure a ajuda de pessoas que tem muitas conexões, conhecem } \\
\text { muita gente na empresa. }\end{array}$ \\
\hline Antes & Inclua Comida & Transforme uma reunião comum em um evento incluindo comida. \\
\hline Antes & e-Fórum & $\begin{array}{l}\text { Crie um boletim eletrônico, lista de discussão, Wiki para aqueles } \\
\text { que desejam saber mais sobre o assunto. }\end{array}$ \\
\hline Antes & $\begin{array}{l}\text { Os que } \\
\text { Adotam } \\
\text { Cedo }\end{array}$ & $\begin{array}{l}\text { Ganhe apoio de pessoas que podem ser líderes de opinião sobre a } \\
\text { nova ideia. }\end{array}$ \\
\hline Antes & $\begin{array}{l}\text { Validação } \\
\text { Externa }\end{array}$ & $\begin{array}{l}\text { Aumente a credibilidade da ideia trazendo informações de fontes } \\
\text { fora da empresa. }\end{array}$ \\
\hline Antes & $\begin{array}{l}\text { Identidade do } \\
\text { Grupo }\end{array}$ & $\begin{array}{l}\text { Dê ao esforço de mudança uma identidade para que as pessoas } \\
\text { reconheçam sua existência. }\end{array}$ \\
\hline Antes & $\begin{array}{l}\text { Guru ao Seu } \\
\text { Lado }\end{array}$ & $\begin{array}{l}\text { Tenha ao seu lado seniores que têm a opinião respeitada pelos } \\
\text { membros da organização. }\end{array}$ \\
\hline Antes & No seu Espaço & Mantenha sua ideia visível espalhando lembretes pela organização. \\
\hline Antes & Inovador & $\begin{array}{l}\text { Ao começar a iniciativa às mudanças, peça ajuda a pessoas que } \\
\text { gostam de novas ideias. }\end{array}$ \\
\hline Antes & $\begin{array}{l}\text { Simplesmente } \\
\text { Faça }\end{array}$ & $\begin{array}{l}\text { Prepare-se para espalhar a palavra sobre sua nova ideia usando-a } \\
\text { em seu próprio trabalho para descobrir seus benefícios e limitações. }\end{array}$ \\
\hline Antes & Diga Obrigado & $\begin{array}{l}\text { Para mostrar sua gratidão, diga "Obrigado" da maneira mais sin- } \\
\text { cera que você puder para todos que o ajudarem. }\end{array}$ \\
\hline Antes & $\begin{array}{l}\text { Próximos } \\
\text { Passos }\end{array}$ & $\begin{array}{l}\text { Reserve um tempo no final de cada evento sobre sua nova ideia } \\
\text { para dizer aos participantes o que eles podem fazer depois. }\end{array}$ \\
\hline Antes & Toque Pessoal & $\begin{array}{l}\text { Convença as pessoas mostrando como sua nova ideia para ser pes- } \\
\text { soalmente útil e valiosa para elas. }\end{array}$ \\
\hline Antes & Adendo & $\begin{array}{l}\text { Encontre uma maneira de ligar sua nova ideia com alguma prática } \\
\text { já existente. }\end{array}$ \\
\hline Antes & $\begin{array}{ll}\text { Plante as } \\
\text { Sementes }\end{array}$ & $\begin{array}{l}\text { Para despertar interesse, carregue materiais (sementes) e mostre- } \\
\text { os (plante) quando surgirem oportunidades. }\end{array}$ \\
\hline
\end{tabular}




\begin{tabular}{|c|c|c|}
\hline Tema & Padrão & Resumo \\
\hline Antes & A Hora Certa & $\begin{array}{l}\text { Leve em conta a hora quando agendar uma reunião ou pedir ajuda } \\
\text { aos outros. }\end{array}$ \\
\hline Antes & $\begin{array}{l}\text { Manter } \\
\text { Contato }\end{array}$ & $\begin{array}{l}\text { Uma vez que você já tem a lista das pessoas chave, não se esqueça } \\
\text { delas nem deixe que elas se esqueçam de você. }\end{array}$ \\
\hline Antes & $\begin{array}{ll}\text { Grupo de } \\
\text { Estudos }\end{array}$ & $\begin{array}{l}\text { Forme um pequeno grupo que esteja interessado em explorar e } \\
\text { continuar a aprender sobre determinado assunto. }\end{array}$ \\
\hline Antes & $\begin{array}{l}\text { Terno } \\
\text { Alfaiate }\end{array}$ & Associe sua mensagem às necessidades da empresa. \\
\hline Durante & Evangelista & $\begin{array}{l}\text { Para começar a introduzir uma nova ideia numa organização, faça } \\
\text { tudo que for possível para mostrar sua paixão. }\end{array}$ \\
\hline Durante & $\begin{array}{l}\text { Pequenos } \\
\text { Sucessos }\end{array}$ & $\begin{array}{l}\text { Para evitar o desgaste de todas as coisas que precisa fazer e os } \\
\text { desafios a serem enfrentados, comemore mesmo os pequenos su- } \\
\text { cessos. }\end{array}$ \\
\hline Durante & Passo a Passo & $\begin{array}{l}\text { Alivie a frustração que a enorme tarefa de mudar toda a empresa } \\
\text { traz dando um passo de cada vez em direção ao seu objetivo. }\end{array}$ \\
\hline Durante & $\begin{array}{l}\text { Experimente a } \\
\text { Água }\end{array}$ & $\begin{array}{l}\text { Diante de uma nova oportunidade, use esses padrões para testar } \\
\text { e avaliar os resultados. }\end{array}$ \\
\hline Durante & $\begin{array}{l}\text { Tempo para } \\
\text { Reflexão }\end{array}$ & $\begin{array}{l}\text { Para aprender sobre o passado, tire periodicamente um tempo } \\
\text { para avaliar sobre o que funcionou e o que não. }\end{array}$ \\
\hline Depois & $\begin{array}{l}\text { Grande } \\
\text { Personalidade }\end{array}$ & $\begin{array}{l}\text { Convide uma pessoa importante para falar sobre a sua ideia dentro } \\
\text { da empresa. }\end{array}$ \\
\hline Depois & $\begin{array}{l}\text { Anjo } \\
\text { Corporativo }\end{array}$ & $\begin{array}{l}\text { Para alinhar a inovação aos objetivos da corporação, obtenha } \\
\text { ajuda de um alto executivo. }\end{array}$ \\
\hline Depois & $\begin{array}{l}\text { Defensor } \\
\text { Dedicado }\end{array}$ & $\begin{array}{l}\text { Coloque a iniciativa à mudança como descrição do seu próprio } \\
\text { trabalho. }\end{array}$ \\
\hline Depois & $\begin{array}{l}\text { Primeira } \\
\text { Maioria }\end{array}$ & Para espalhar sua ideia, você precisa convencer a grande maioria. \\
\hline Depois & $\begin{array}{l}\text { Revisão do } \\
\text { Guru }\end{array}$ & $\begin{array}{l}\text { Coloque todos os Gurus ao Seu Lado para avaliarem as novas } \\
\text { ideias. }\end{array}$ \\
\hline Depois & $\begin{array}{l}\text { Histórias para } \\
\text { Contar }\end{array}$ & $\begin{array}{l}\text { Encoraje as pessoas que tiveram sucesso com a nova ideia a con- } \\
\text { tarem suas histórias. }\end{array}$ \\
\hline Depois & Envolva Todos & $\begin{array}{l}\text { Todos devem ter condições de suportar a inovação e fazer sua } \\
\text { contribuição pessoal. }\end{array}$ \\
\hline
\end{tabular}




\begin{tabular}{|c|c|c|}
\hline Tema & Padrão & Resumo \\
\hline Depois & O Suficiente & $\begin{array}{l}\text { Para facilitar o aprendizado de um conceito difícil, dê apenas } \\
\text { uma breve introdução e deixe outras informações disponíveis para } \\
\text { quando as pessoas estiverem prontas. }\end{array}$ \\
\hline Depois & $\begin{array}{l}\text { Patrocinador } \\
\text { Local }\end{array}$ & $\begin{array}{l}\text { Peça ajuda à gerência. Quando seu chefe apoia as tarefas que } \\
\text { você está fazendo para introduzir a nova ideia, você pode ter mais } \\
\text { eficácia. }\end{array}$ \\
\hline Depois & $\begin{array}{l}\text { Local, Local, } \\
\text { Local }\end{array}$ & $\begin{array}{l}\text { Para evitar interrupções que perturbam o fluxo de um evento, } \\
\text { tente fazer eventos importante fora do escritório. }\end{array}$ \\
\hline Depois & Mentor & $\begin{array}{l}\text { Quando um projeto quiser começar com a nova ideia, tenha por } \\
\text { perto alguém que a conhece e pode ajudar. }\end{array}$ \\
\hline Depois & $\begin{array}{l}\text { Audiência } \\
\text { Real }\end{array}$ & $\begin{array}{l}\text { Arrume um modo da gerência da empresa passar um tempo com } \\
\text { uma Grande Personalidade }\end{array}$ \\
\hline Depois & $\begin{array}{l}\text { Ombro para } \\
\text { Chorar }\end{array}$ & $\begin{array}{l}\text { Para não perder a coragem quando as coisas ficarem difíceis, con- } \\
\text { verse com outros que também estão penando para introduzir a } \\
\text { ideia. }\end{array}$ \\
\hline Depois & $\begin{array}{l}\text { O Cheiro do } \\
\text { Sucesso }\end{array}$ & $\begin{array}{l}\text { Quando o resultado dos seus esforços é positivamente visível, as } \\
\text { pessoas virão falar com você. Trate essa oportunidade como um } \\
\text { momento de aprendizado. }\end{array}$ \\
\hline Depois & $\begin{array}{l}\text { Momento } \\
\text { Sustentável }\end{array}$ & $\begin{array}{l}\text { Tenha uma atitude pró-ativa no trabalho de sustentar o interesse } \\
\text { pela nova ideia. }\end{array}$ \\
\hline Depois & Brinquedinho & $\begin{array}{l}\text { Para tornar a sua ideia presente na mente das pessoas, presenteie- } \\
\text { as com brinquedos, chaveiros que possam ser identificados como } \\
\text { símbolo da sua ideia. }\end{array}$ \\
\hline Resistência & $\begin{array}{l}\text { Construtor de } \\
\text { Pontes }\end{array}$ & Pareie os que aceitaram a nova ideia com aqueles que não. \\
\hline Resistência & $\begin{array}{l}\text { O Cético } \\
\text { Defensor }\end{array}$ & $\begin{array}{l}\text { Peça ajuda a um líder que seja cético em relação à sua nova ideia } \\
\text { para fazer o papel de "cético oficial". Use os comentários dele para } \\
\text { melhorar seus esforços, mesmo que ele não mude de ideia. }\end{array}$ \\
\hline Resistência & $\begin{array}{l}\text { Política de } \\
\text { Corredor }\end{array}$ & $\begin{array}{l}\text { Trabalhe informalmente com tomadores de decisão antes de uma } \\
\text { votação importante para e certificar que eles entendem completa- } \\
\text { mente as consequências de suas decisões }\end{array}$ \\
\hline
\end{tabular}




\begin{tabular}{|l|l|l|}
\hline Tema & Padrão & Resumo \\
\hline Resistência & Sem Medo & Use a resistência à nova ideia a seu favor. \\
\hline Resistência & $\begin{array}{l}\text { Rodada de } \\
\text { Testes }\end{array}$ & $\begin{array}{l}\text { Quando a empresa não estiver interessada em aplicar a nova ideia, } \\
\text { sugira que ela experimente por um pequeno período e estude os } \\
\text { resultados. }\end{array}$ \\
\hline Resistência & $\begin{array}{l}\text { Sussurre no } \\
\text { Ouvido do } \\
\text { General }\end{array}$ & $\begin{array}{l}\text { Alguns gerentes são difíceis de convencer numa reunião de grupo. } \\
\text { Fale com eles em particular. }\end{array}$ \\
\hline
\end{tabular}

Tabela 2.1: Resumo dos Padrões para Introduzir Novas Ideias

\subsection{Limitações da Abordagem}

A utilizações dos Padrões para Introduzir Novas Ideias se mostrou bastante eficaz, porém não podemos contar apenas com essa ferramenta quando queremos implantar uma nova ideia. Muitas vezes a ideia nova, que acreditamos ser boa, pode eventualmente não ser adequada para o contexto na qual estamos querendo agir (e pode ser que não saibamos disso). Mesmo que utilizemos os melhores padrões, as pessoas podem até mudar superficialmente, mas se no fim não acreditarem de verdade em nossas ideias, fatalmente voltarão a se comportar como antes. Todo nosso trabalho de mudança estará perdido. Tentamos ajudar da forma que acreditamos ser a melhor, mas nem sempre nossas convicções são a melhor coisa para os outros.

Os padrões não garantem que conseguiremos de fato convencer as pessoas. Se quisermos, por exemplo, implantar uma nova ideia numa organização que funciona baseada num comando centralizado, precisamos quase sempre ter o apoio total do comando central. Se o presidente da empresa for muito centralizador e todas as decisões importantes passarem pela sua mão, dificilmente conseguiremos mudar as pessoas sem antes convencer o próprio presidente de que nossa ideia é o melhor caminho. Além disso, quando o presidente é centralizador, dificilmente ele ouvirá nossas ideias e, portanto, pouco se tem a fazer nesses casos.

Se você estiver agindo em um ambiente pouco aberto para novas ideias, também será muito difícil aplicar uma mudança. O contexto em que nos encontrávamos para aplicar os Padrões para Introduzir Novas Ideias, com o objetivo de implantar métodos ágeis dentro de uma organização, era relativamente favorável. Tivemos uma resistência inicial, mas por ser uma empresa de tecnologia, preocupada com inovações, fomos ganhando uma certa liberdade para agir. Num certo momento o diretor nos pediu para treinarmos a empresa toda, ou seja, ele nos apoiou, o que nem sempre será o caso. Você pode ter um diretor que faz parte do grupo dos Retardatários, o que complicará bastante seu trabalho, isso se não inviabilizá-lo completamente. 
Trabalhar com questões que envolvem mudanças culturais exigem, acima de tudo, muita paciência de sua parte. Algumas pessoas não conseguem esperar até que a mudança se processe. O padrão Hora Certa ${ }^{48}$ é muito importante nessas horas, mas nem todos conseguem aplicá-lo. O padrão Faça Arte ${ }^{49}$ exige um conhecimento prévio de alguma modalidade artística, o que nem sempre é o caso. Claro que, em último caso, você sempre pode encontrar um Ombro para Chorar ${ }^{50}$. Isso irá aliviar suas tensões e fará você se sentir bem, mas o seu objetivo principal, que é ter a uma nova ideia adotada, não será atingido só porque você chorou. No fim, você terá que se conformar com o fato de que nem todas as coisas estão sob seu controle.

\footnotetext{
${ }^{48}$ Vide Seção 2.4.4.

${ }^{49}$ Vide Seção 3.4.

${ }^{50}$ Vide Seção 2.6.3.
} 
2 Padrões para Introduzir Novas Ideias 


\section{Sugestões de Novos Padrões}

Nesta seção, apresentaremos quatro propostas de novos padrões. Essas propostas foram experimentados por nós apenas uma vez. Como não conhecemos outras ocorrências deles, os colocamos como sugestões, para que outras pessoas os experimentem e os transformem em verdadeiros padrões que ajudem a introduzir uma ideia.

Usaremos o mesmo estilo do livro de Rising e Manns. No livro, as autoras contam uma pequena história relacionada ao padrão. Essa história aparece em itálico. Em seguida, em negrito, colocam uma frase curta e objetiva que descreva o padrão. Depois, descrevem o padrão com maiores detalhes.

\subsection{Brinque com Eles (Let Them Play)}

Há muito tempo tinha vontade de implementar Métodos Ágeis de Desenvolvimento dentro da empresa. Quando tentava tocar no assunto com algum alto executivo, parecia tudo sempre muito difícil e pesado. Decidi realizar então o Jogo de XP [SMWW02]. Após esse evento, as pessoas ficavam entusiasmadas ao falar sobre o assunto. O jogo despertou um lado lúdico-artístico, natural, humano e as pessoas ficaram satisfeitas com esse tipo de vivência dentro da empresa.

Quando um determinado assunto é considerado extremamente sério e pesado, invente uma brincadeira que fale sobre esse assunto e faça as pessoas brincarem.

O jogo de XP em si não tem por objetivo ensinar com precisão todas as práticas da metodologia, mesmo porque o aprendizado de XP é algo complexo. Mas algumas práticas da metodologia são vistas no jogo. As situações reais são simuladas usando-se atividades lúdicas. As histórias dos clientes são divertidas e instigam as pessoas a conhecerem de fato a metodologia.

Domenico De Masi descreve um espaço onde o trabalho, o lazer e o estudo convivem harmoniosamente. Ele chama esse espaço de "Ócio Criativo"[DM00]. Este espaço está representado pela região 7 na Figura 3.1 A revolução industrial trouxe ao mundo moderno uma ideia que separa o trabalho da vida pessoal de um indivíduo. As linhas de produção têm por objetivo maximizar a utilização do tempo e espaço de forma a obter o maior lucro. Na linha de produção, o primeiro operário aperta parafuso, o próximo bate com o martelo, o próximo verifica se o parafuso foi bem 


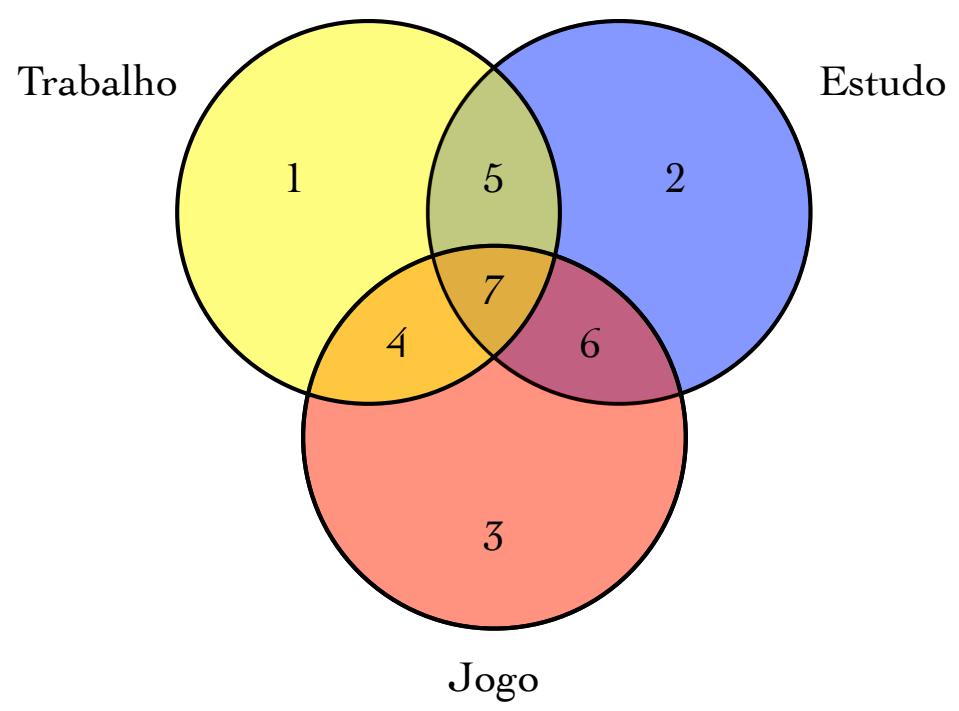

Figura 3.1: Esquema: Trabalho $x$ Estudo $x$ Jogo

apertado e assim por diante. No mundo pós-moderno, máquinas substituem cada vez mais os operários. O homem passa do trabalho braçal para o intelectual. O trabalho criativo é o novo modelo para o mundo atual. Nesse contexto, o homem pode retomar hábitos medievais, onde trabalho, lazer e estudo estão integrados num mesmo ambiente.

"Brincar com eles" é uma forma de trazer o espaço do "Ócio Criativo" para o ambiente de trabalho, normalmente formal. Ao sair da formalidade, as pessoas ficam naturalmente mais abertas, não só para ouvir novas ideias, mas também para para criar.

Isso significa que o homem volta ao estado onde é permitido trabalhar em casa. É permitido parar no meio do dia para uma folga, trocar o dia pela noite, ter horários flexíveis. A medição da quantidade de trabalho realizado tornou-se mais subjetiva. Não é a quantidade de linhas de código que tem valor, mas a qualidade do software, a quantidade de funcionalidades que determinado sistema possui ou a facilidade que o usuário tem quando utiliza esse sistema.

\subsection{Mergulhe Fundo}

Eu estava cansado de escrever minha dissertação. As ideias não estavam claras, os argumentos não vinham à cabeça. Estava começando a me desmotivar. Quanto menos eu encarava o texto, 
menos eu queria saber dele. As ideias começaram a se perder. Certo dia decidi mergulhar no trabalho. Me propus a ficar doze horas seguidas pensando e escrevendo sobre o assunto. Era apenas aquela vez, um tratamento de choque. Mesmo que nada viesse, ficaria focado no assunto. Não atenderia telefonemas, não leria emails, não navegaria na Internet. Ficaria o dia todo em cima dos artigos, livros e o texto. $O$ dia acabou sendo muito produtivo. Percebi que o cansaço vinha muito mais da aversão de ter que fazer o trabalho do que do próprio trabalho em si. Após esse dia turbinado, a motivação voltou e eu pude retomar o ritmo que vinha tendo até então.

Para retomar a ideia ou se aprofundar num assunto, mergulhe fundo e passe um período inteiro focado.

Esse padrão serve para retomar uma boa ideia que começou a se perder. Para isso, promova sessões intensas em que as pessoas fiquem em contato permanente com a ideia.

Muitas vezes uma boa ideia se perde no meio de outras prioridades ou outros afazeres. As pessoas estão sempre muito atarefadas e perdem o foco com facilidade. Esse padrão ajuda a retomar o foco. Com ele você deve estimular um pensamento constante e profundo sobre a ideia. Fazer as pessoas ficarem algumas horas falando, ouvindo e pensando sobre o assunto. Se possível, fazê-las sonhar com a ideia.

Esse padrão está relacionado com o padrão Local, Local, Local ${ }^{1}$, mas ele sugere algo a mais. Você não irá apenas remover as pessoas do seu lugar habitual. Irá submetê-las a um tratamento intensivo. Você vai estimular todos a mergulhar fundo. O assunto que você quer ensinar não será visto apenas de forma superficial. Serão dados detalhes íntimos e todos devem refletir, questionar, argumentar. Nesse trabalho intenso poderão aparecer tanto elogios quanto críticas e ceticismo. O importante é olhar de frente para tudo e esclarecer todas as dúvidas do público.

Toda essa intensidade não significa que o processo precise ser doloroso. Tudo pode ser feito de forma lúdica, organizada. Você pode usar Inclua Comida ${ }^{2}$ para tornar as coisas mais leves. Você também pode usar Arte no processo, estimulando as pessoas a fazerem teatro ou música, como explicado no padrão Faça Arte ${ }^{3}$.

Alunos de Computação do IME-USP que trabalham no projeto InterGrade promovem maratonas de programação, com o objetivo de mergulhar fundo no código do projeto. Basicamente, as maratonas são longas reuniões nas quais os desenvolvedores do InteGrade programam novas funcionalidades, fazem testes, resolvem bugs e refatoram o código existente. Essas reuniões eram mais direcionadas à refatoração, mas a partir de 2008 assumiram um caráter mais geral e passaram a englobar mais atividades [int09].

Eventualmente, esse padrão pode trazer desconforto a algumas pessoas. Nem todos estão

\footnotetext{
${ }^{1}$ Vide Seção 2.9.6.

${ }^{2}$ Vide Seção 2.4.3.

${ }^{3}$ Vide Seção 3.4 .
} 
preparados, ou querem, mergulhar fundo. Tente escolher as pessoas certas para essas atividades intensas e faça 0 Suficiente ${ }^{4}$. Deixe claro às pessoas que essa atividade intensa é temporária e tente de alguma forma explicar os seus objetivos sobre retomar uma boa ideia perdida.

\subsection{ComPARtilhe}

Uma das práticas mais importante da Metodologia XP é a Programação em Pares. Um dos objetivos dessa prática é que o conhecimento seja disseminado rapidamente. Com isso, a propriedade coletiva do código é mantida e valorizada pelo time. A prática em pares tem vários benefícios e vários estudos científicos, principalmente os realizados por Laurie Williams [WL07] [WK02], comprovam a eficácia dessa forma de trabalho em vários aspectos.

TODO citar Organizatonal Patterns of Agile Software Development James O. Coplien - Neil B. Harrison Pearson Prentice Hall 2005

Uma nova ideia, para vingar, precisa ser comunicada. Ela precisa ser claramente entendida por todos. Toda comunicação envolve pelo menos duas partes: a parte que comunica e a parte que ouve. Não há comunicação sem o par Mensageiro-Receptor.

\section{Para disseminar uma ideia, faça as pessoas trabalharem em pares.}

O trabalho em par por si só já induz a comunicação. A proposta do padrão Construtor de Pontes $^{5}$ é de colocarmos céticos e pessoas que adotam cedo para trabalharem em pares. No padrão CompPARtilhe temos que parear todos com todos, para que a comunicação flua mais rápido. Depois de fazer o Construtor de Pontes ${ }^{6}$, podemos pegar o cético que já foi introduzido à nova ideia e fazêlo trabalhar com outro cético. Ninguém melhor do que um cético para convencer outro cético. Dessa forma a ideia é disseminada por um sistema de células ${ }^{7}$. Um transmite para o próximo que transmite para o próximo e assim por diante, como uma disseminação viral, que costuma ser muito eficaz.

Quando falamos sobre uma ideia, a própria ação de falar sobre ela nos ajuda desenvolver a ideia dentro de nós mesmos. Quando falamos, temos a oportunidade de nos ouvir. Temos também a chance de ouvir o outro para entender as diferenças de pontos de vista e elaborar uma melhor abordagem sobre aquele assunto.

Ao colocar pessoas de vários níveis trabalhando juntas, os novatos têm a oportunidade de aprenderem com os mais experientes. Essa é uma prática que motiva bastante as pessoas. Também é uma ótima forma de os mais experientes desenvolverem suas habilidades de transmitir conhecimento

\footnotetext{
${ }^{4}$ Vide Seção 2.9.3.

${ }^{5}$ Vide Seção 2.11.1.

${ }^{6}$ Vide Seção 2.11.1.

${ }^{7}$ Não há um lugar centralizado ou único onde existe a informação. O conhecimento e a informação existem, mas de forma descentralizada [BB06].
} 
e de se sentirem importantes ao dividir sua bagagem com os outros.

Algumas vezes, as pessoas têm naturalmente uma tendência ao isolamento e ao egoísmo. Forçar a interação ajuda elas a resgatar o contato e a perceber que é no contato que existe maior produtividade e prazer. Essa forma de troca é muito característica no que conhecemos hoje como Gift-Economy ${ }^{8}$. Esse tipo de economia é o que move algumas das principais iniciativas no mundo do Software Livre [GG05], [GG00].

Apesar de ser um padrão que facilita a disseminação de informação, nem todos estão preparados para trabalhar em pares. Algumas pessoas simplesmente se recusam a trabalhar dessa forma. Você deve ir devagar com essas pessoas e respeitar seus limites. Outra possibilidade que não se deve despresar é a de uma dupla cética iniciar um movimento para derrubar a sua ideia. Quando você permite que as pessoas se unam num "bem" comum, nem sempre esse bem é o que você quer. Esteja preparado para encarar essas situações.

\subsection{Faça Arte}

Eu queria convencer as pessoas de que o uso de testes automatizados era benéfico e fundamental para o desenvolvimento de software de qualidade [BK08]. Mesmo depois de falar muito sobre o assunto e mostrar muitos livros e artigos sobre testes, parecia que as pessoas ainda não tinham se convencido de que usá-los era realmente importante. Decidi então compor uma paródia sobre o tema. Percebi que após ouvir a composição, as pessoas começaram a simpatizar mais com testes.

(com a melodia de Tiro ao Álvaro de Adoniram Barbosa)

De tanto enfiar

Gambiarra pra funcionar

Meu código até

Parece sabe o quê?

Maaaa-caarronada da mama

Eu vou ter que refatorar

(assim não pode ficar)

Se esse método for colocado na classe acima

Esse outro a gente lima

Vou com teste completando

Vou testar

\footnotetext{
${ }^{8}$ Economia fundamentalmente baseada em cordialidade, gratificações e valores morais e éticos [Che88].
} 
Prá acabar com esse sofrimento

Não aguento

Vou fazer

O teste automatizado

\section{Para implantar uma ideia no inconsciente das pessoas, faça Arte.}

Existem várias formas de se fazer Arte com o objetivo de introduzir uma nova ideia:

- Pode-se compor uma música sobre o tema a ser introduzido e ensinar as pessoas a cantarem a música;

- Escrever uma poesia cujo tema lembre a ideia;

- Criar uma cena de teatro, que tenha a ideia a ser introduzida como tema implícito ou explícito. Convidar as pessoas envolvidas a participarem da encenação;

- Criar um desenho ou uma imagem a ser usada No Seu Espaço ${ }^{9}$;

- Fazer um escultura (pode ser uma feita com massinha de criança). Não é necessário ser um grande escultor para fazer uma escultura.

- Forçar as pessoas a pensarem de forma lúdica sobre a sua ideia, propondo algum tipo de jogo ou dinâmica de grupo, como no padrão Brinque com Eles ${ }^{10}$. As coisas podem ser sérias e ao mesmo tempo lúdicas e divertidas (Dojo).

Uma divisão de tecnologia puramente baseada em computadores não é capaz de criar. O computador não cria! Quem cria é o ser humano. Algumas ideias sobre como substituir o pensamento computacional pelo artístico são sugeridas por Setzer [Set06a]. Para se programar ou usar um computador, é necessário formular os pensamentos dentro de um espaço abstrato, matemático. Segundo Setzer,

"a Ciência é a ideia tornada conceito; a Arte é a ideia tornada objeto. Isto é, ambas têm a mesma origem, mas uma é expressa por meio de abstrações, e é captada pelo nosso pensamento, enquanto a outra é concretizada em algo que pode ser captado pelos nossos sentidos" [Set97]

A Arte também ajuda a desenvolver sensibilidade social, empatia. Os programadores que não tiverem no seu dia-a-dia atividades que incentivem a sociabilidade estão propensos a desenvolver

\footnotetext{
${ }^{9}$ Vide Seção 2.9.4.

${ }^{10}$ Vide Seção 3.1.
} 
uma visão distorcida da realidade. Eles tendem a acreditar que o ser humano funciona da mesma forma que as máquinas. Essa visão pode ser extremamente maléfica, não só para a vida desses indivíduos como para as pessoas que os cercam.

Além de agir no lado inconsciente, a Arte promove encontro, troca de conhecimento e de experiências. A Arte também ajuda a aliviar o estresse (tanto a praticada quanto a apreciada). Basta existir um espaço vazio, em branco, que logo as pessoas começam a criar. A folha branca é a oportunidade para um novo desenho.

Esse padrão deve ser usado com cautela. Nem sempre as pessoas encaram Arte como algo sério no ambiente de trabalho. Elas podem pensar que você está brincando e fugindo do seu verdadeiro trabalho. Alguns podem não entender que a expressão artística é parte do seu trabalho. Faça $\mathrm{O}$ Suficiente $^{11}$ e na Hora Certa ${ }^{12}$. Além disso, nem todos gostam de todos os tipos ou estilos de Arte. Use cada estilo para o público adequado. Saiba reconhecer o seu público e aplicar a forma correta para cada plateia específica.

Os Padrões para Introduzir Novas ideias podem ser usados em vários contextos, para introduzir qualquer ideia em todos os tipos de organizações (não necessariamente em empresas que desenvolvem software). Mas o contexto em que estamos interessados é o de desenvolvimento de software. Acreditamos que o padrão Faça Arte é o mais importante dos quatro sugeridos, principalmente nesse contexto. Por essa razão, dedicaremos o próximo capítulo a mostrar o quanto a Arte é poderosa na tarefa de introduzir uma nova ideia e falaremos sobre alguns pontos em que a Arte está relacionada com desenvolvimento de software.

\footnotetext{
${ }^{11}$ Vide Seção 2.9.3.

${ }^{12}$ Vide Seção 2.4.4.
} 
3 Sugestões de Novos Padrões 


\section{Atividades Artísticas, Meditação e Padrões}

A Programação Extrema defende que uma equipe mantenha um ritmo sustentável de trabalho em semanas de 40 horas, praticando o que Kent Beck chama de Trabalho Energizado [BA04]. Produzir software não é como produzir parafusos. Numa linha de produção de fábrica, colocar mais um homem trabalhando significa maior quantidade de produto final. Em criação de sistemas, o crescimento da quantidade de produtos (software funcionando) não é proporcional ao número de pessoas trabalhando. Algumas vezes, adicionar pessoas ao processo acaba piorando a produtividade do grupo [Bro95]. A popularização dos Métodos Ágeis trouxe muitas mudanças e quebra de preconceitos trazidos da revolução industrial, como o de achar que software pode ser criado facilmente usando linhas de produção. Ainda assim, existem muitos paradigmas a serem quebrados. Na era industrial, a fórmula de um produto era guardada a sete chaves. Essa fórmula secreta garantia que o produto não seria copiado. Naquela época, a exclusividade na comercialização de produtos foi muito lucrativa para as indústrias.

A partir do surgimento da Internet, a informação tornou-se muito acessível a todos. As fórmulas secretas deixaram de ser secretas. Com uma simples busca no Google é possível encontrar desde, por exemplo, maneiras de construir uma bomba caseira até técnicas de alta costura ou como fazer chocolates trufados. Nos início dos anos 90, tínhamos um colega de colégio que vendia trufas deliciosas nos intervalos das aulas. Naquela época, ninguém da escola podia imaginar como eram feitas aquelas trufas maravilhosas. Todos compravam, mesmo a um preço muito acima do preço de um doce comum.

Para sobreviver num ambiente globalizado como o do mundo atual, onde produtos podem ser copiados facilmente, as empresas precisam diferenciar-se. Hoje, a diferenciação pode ser encontrada

em dois quesitos: qualidade e inovação. Na área de software, os Métodos Ágeis contribuíram fortemente para criar diferenciação no quesito qualidade, tanto na indústria, quanto no governo e na academia [dS07]. A Arte poderia, então, ser uma ferramenta para a diferenciação no quesito inovação, já que toda obra de Arte é uma criação e, portanto, uma inovação.

Para inovar é preciso criatividade. Todo ser humano possui um lado criativo. E o potencial criativo do homem pode ser explorado, desenvolvido, melhorado. Para desenvolver criatividade 
dentro das empresas, é interessante que existam atividades artísticas no dia-a-dia dos funcionários, os "criadores". Para se conseguir a adoção de atividades artísticas dentro de empresas, pode-se usar os Padrões para Introduzir Novas Ideias. Usar os padrões defendendo a ideia de se usar Arte pode ajudar a desenvolver um ambiente artístico na área de tecnologia de uma empresa de software.

Uma outra abordagem é a de que podemos usar a Arte para introduzir uma nova ideia. Usar a Arte para introduzir uma ideia pode ser considerado um padrão. Quando as pessoas assistem uma peça de teatro, um filme, ou observam uma pintura, elas estão naturalmente num estado de abertura emocional. As pessoas ficam mais receptivas quando se deparam com Arte que apreciam. A Arte age como um motor de mudança, e mudança induz a inovação.

Neste capítulo faremos uma análise de algumas atividades artísticas. Veremos como elas se relacionam com o processo de criação de software. Essas atividades podem ser usadas como Padrões para Introduzir Novas Ideias. E os Padrões já existentes também podem ser usados para disseminar essas atividades dentro do ambiente corporativo.

Faremos também uma seção sobre meditação que, apesar de não ser uma atividade artística, pode ser considerada uma prática que estimula o lado direito do cérebro [Hun08] e, portanto, trabalha aspectos importantes do ser humano que a parte matemática e lógica da computação não necessariamente exercita.

\subsection{Teatro}

Uma das formas de expressão artística mais completas é o teatro. Isso porque o teatro muitas vezes contém em si outras formas de expressão. O teatro traz elementos físicos que permitem o contato do ator e do espectador com as outras artes como a poesia, a música, a dança. O teatro foi a Arte que mais motivou e inspirou a realização deste trabalho.

Em uma época não muito distante, seria muito difícil imaginar como o teatro e a Computação poderiam contribuir um com o outro. Porém, nos dias de hoje fica fácil imaginar que a Computação e, de uma forma mais geral, a tecnologia pode contribuir para o teatro [Pin97]. Toda produção teatral requer recursos tecnológicos de luz, som, elaboração de cenários, figurinos, etc. Inevitavelmente, uma peça teatral utilizará um software de edição de som (direta ou indiretamente), ou um software de design (para o cenário, ou mesmo para a divulgação através de panfletos). Seguindo a tendência mundial de que hoje todas as coisas produzidas pelo ser humano (ou quase todas) utilizam algum recurso tecnológico, o teatro não poderia ser diferente.

O objetivo desse trabalho não é refletir sobre como a tecnologia pode ser usada como ferramenta para as criações artísticas. O que queremos é mostrar como a Arte pode contribuir para o desenvolvimento e maturação dessa tecnologia. É a Arte que cria tecnologia. Isso porque a Arte 
vem da percepção criativa do ser humano, algo totalmente desvinculado de qualquer ferramenta tecnológica. O ser humano tem nato o espírito criativo. Segundo Winnicott [Win71],

"É através da percepção criativa, mais do que qualquer outra coisa, que o indivíduo sente que a vida é digna de ser vivida."

O que a maioria das artes propõem, e o que na nossa visão é a base do teatro, é a criação de um espaço lúdico e de convívio social. Esse espaço aberto, não preenchido, será usado para receber a materialização das ideias das pessoas. Winnicott desenvolveu uma teoria que mostra que é no brincar, e talvez apenas no brincar, que a uma pessoa frui sua liberdade de criação. Seja qual for o tipo de criação (tecnológica no nosso caso), ela só será legítima se surgir a partir de um espaço lúdico.

No ano de 2000, pela iniciativa do Prof. Valdemar Setzer, foi criado no Instituto de Matemática e Estatística da Universidade de São Paulo (IME-USP) um curso de Leitura Dramática para alunos de Ciência da Computação [San02]. Desde 2003, a disciplina tornou-se parte do currículo dentre as optativas do curso de Computação. Cerca de 20 alunos se matriculam por semestre na disciplina, ou seja, cerca de 400 alunos da área da Computação já participaram dessa vivência. Os alunos do curso já fizeram cinco montagens teatrais, com o auxílio da Professora Jolanda Gentilezza.

Estudantes de Computação são obrigados a conviver com verdades absolutas, provadas matematicamente. Essa overdose de lógica e pensamento digital contribui para afastar os hackers do contato com sentimentos, relações interpessoais. O teatro tem o papel de equilibrar o pensamento lógico com o lado analógico e imprevisível do ser humano. Além disso, a própria natureza de desenvolver software não segue um processo linear, pronto, bem definido (como é a matemática), mas ciclos de melhorias que visam atender necessidades individuais dos usuários (ver Tabela 4.1). A criação de bom software não é um processo de produção; é um processo de desenvolvimento. Desenvolver é diferente de produzir [PP03]. Desenvolver é como criar uma receita, enquanto que produzir é seguir os passos de uma receita pronta. São atividades diferentes. Desenvolver uma receita é um processo de aprendizado, de tentativa e erro. Quando um grande chefe cria um prato, ele não o cria de primeira. O prato primordial é resultado de um refinamento, de várias tentativas e variações sobre um tema, na busca do resultado perfeito.

Na Disneylândia, existem centenas de atores cujo único trabalho é fazer com que cada visitante tenha momentos maravilhosos. Os requisitos do que é um "momento maravilhoso" muda de visitante para visitante e o trabalho do ator é descobrir o que o visitante vê como experiência de qualidade e se certificar de que ele tenha essa experiência [PP03].

Não existe, na área de software, uma solução ou uma tecnologia que resolva todos os problemas. Não há bala de prata [Bro87]. É fundamental que um programador, além de conhecer a técnica, seja criativo para saber qual tecnologia aplicar em cada caso particular. 


\begin{tabular}{|l|l|}
\hline Desenvolvimento & Produção \\
\hline Projetar a receita & Produzir o prato \\
\hline $\begin{array}{l}\text { - Qualidade é estar de acordo } \\
\text { com o uso }\end{array}$ & $\begin{array}{l}\text { - Qualidade é estar de acordo } \\
\text { com a especificação } \\
\text { - Variações são boas }\end{array}$ \\
• Iterações geram valor & $\begin{array}{l}\text { - Iteraçõesões são ruins } \\
\text { (re-trabalho) }\end{array}$ \\
& \\
\hline
\end{tabular}

Tabela 4.1: Desenvolvimento vs. Produção [PP03]

A visão de qualidade de serviço (e hoje software é serviço [Pin07]) leva em conta que cada cliente tem uma ideia diferente do que significa uma experiência de qualidade. A diferença entre prover um serviço e produzir um produto é que, em serviços, atender a necessidade do cliente requer variações, enquanto que em linhas de produção variações são vistas como inimigas.

Problemas de software possuem várias soluções, em vários níveis, feitas por todos os membros do time. Não só os arquitetos estão envolvidos, mas todos os desenvolvedores. Escrever código envolve um entendimento profundo do problema, reconhecer padrões, experimentar várias abordagens, testar os resultados. Para isso, o melhor processo é aquele que consiste em ciclos curtos de aprendizado.

Resumindo, a natureza de desenvolver software está ligada a criar soluções personalizadas e variáveis e a estabelecer um processo iterativo de aperfeiçoamento. O teatro incorpora elementos lúdicos que permitem desenvolver habilidades humanas, logo facilita a criação de soluções variáveis e adaptadas a cada plateia. Ele também possui por natureza um processo iterativo de aperfeiçoamento (cada ensaio visa refinar mais e mais uma personagem, um texto, uma encenação). Concluindo, há semelhanças entre o teatro e o desenvolvimento de software.

Um benefício direto da prática teatral é o aprimoramento da habilidade de comunicação. O contato com textos de qualidade promovem o desenvolvimento linguístico. Atuar contribui para o desenvolvimento e formação de líderes comunicativos. Um dos fatores que colabora para o sucesso das empresas é a qualidade da comunicação entre seus funcionários.

O teatro também ensina a lidar com emoções. Ele ajuda na difícil tarefa de reconhecê-las e de perceber suas consequências na mente e no corpo. Além de reconhecer os próprios sentimentos, cada ator desenvolve a empatia, capacidade de reconhecer o sentimento de outras pessoas. Isso ajuda as pessoas a trabalharem em equipe, aprimorando os espaços colaborativos. 
Ao participar de atividades teatrais, as pessoas têm a oportunidade de desenvolver suas habilidades criativas. No teatro é permitido criar sem limites. Lá é permitido ser diferente e inventar. Todo bom programador quer, no fundo, isso: criar coisas boas (no caso bons programas).

As ciências Exatas e a Computação contêm conhecimentos técnicos fundamentais para um grande programador. Essa técnica ele desenvolve diariamente em seu trabalho natural e estudos. A proposta do uso do teatro (e de outras vivências humanistas e artísticas) é desenvolver a capacidade criativa e levar o programador a usar todo o seu conhecimento técnico e lógico para inovar.

A Lógica, a Matemática, a Computação, são ferramentas. São técnicas. Conhecer a técnica é fundamental. Mas existe um conhecimento anterior à técnica que deve ser desenvolvido: o conhecimento do que é não-definido (ou mal-definido). O contato com o incerto, o analógico. A vivência com o próprio corpo, a experiência objetiva com sensações. São essas vivências que desenvolvem a criatividade e a comunicação. Quando unimos criação e comunicação com conhecimento técnico e força de trabalho numa empresa de software, temos o ambiente ideal para o surgimento de grandes produtos tecnológicos.

O mercado de hoje é extremamente competitivo. Poucas pessoas conseguem, sozinhas, desenvolver bom software. Cada vez mais se exige sistemas grandes, cheios de funcionalidades, fáceis de serem utilizados. Mais ainda, os sistemas devem interagir entre si. Vários times, com muitas pessoas, são responsáveis por desenvolver e manter sistemas. Esses times se relacionam das mais diversas maneiras [Eva04]. No futuro, a tendência é que seja mais complexo ainda. Teremos sistemas com 1 trilhão de linhas de código, rodando simultaneamente em milhões de computadores interagindo entre si em tempo real $\left[\mathrm{NFG}^{+} 06\right]$. Nenhum ser humano é capaz de desenvolver sozinho um sistema desses [Gab06]. Num cenário onde várias pessoas interagem, só é possível construir sistemas complexos com qualidade, se essa interação for eficiente. As pessoas precisam se comunicar muito bem, muitas vezes tendo que seguir padrões pré-acordados de linguagem ${ }^{1}$. Daí a importância de cada um, individualmente, desenvolver habilidades de comunicação. O teatro é mais uma forma de expressão artística que ajuda a desenvolver a capacidade de comunicação de um indivíduo.

Numa retrospectiva após a primeira turma de leitura dramática no IME-USP, Jolanda Gentileza, a professora, tirou algumas conclusões importantes baseadas em depoimentos e conversas com os próprios alunos:

- A surpresa mais agradável é que todos relataram uma mudança notável na questão da timidez pessoal.

- Todos gostaram muito do trabalho corporal, que encararam como "verdadeiras sessões de relaxamento, ótimas para o alívio da tensão semanal" predispondo assim à percepção daquilo

\footnotetext{
${ }^{1}$ Ver Linguagem Ubíqua em [Eva04].
} 
que Jolanda chama de "musculatura da timidez".

- Acharam as leituras dos textos "muito divertidas" e gostariam de ter mais leituras do gênero. (Leram "Lisístrata" de Aristófanes; "Édipo Rei" de Sófocles; "O Doente Imaginário" de Molière; muitas poesias e trechos de outros vários autores).

- Gostaram muito dos "jogos teatrais" porque (usaram a seguinte expressão): "passar vexame juntos" ou "pagar mico juntos" faz perder a inibição.

- Pediram menos teoria, mas isso é óbvio, sempre o aluno pedirá menos teoria... Em todo caso, sempre se pode tentar dar a cara de menos teoria, escondendo-a cada vez mais na parte prática. E nisso eles têm toda razão, pois passam o dia todo na teoria.

O Professor Valdemar Setzer escreveu após assistir à encenação da primeira peça do grupo quIMEra (grupo dos alunos do IME):

"O grupo formou-se com alunos de uma disciplina extra-curricular de Leitura Dramática, dada no semestre passado por iniciativa do Conselho do MAC. A peça não foi lida ${ }^{2}$, isto é, eles fizeram muito mais do que se poderia esperar de uma disciplina dessas, isto é, mostrou-se como é possível criar entusiasmo nos alunos.

A peça foi escrita pela instrutora da disciplina, Da. Jolanda Gentilezza, atriz, diretora, dramaturga, etc. com a colaboração dos alunos. Eu havia assistido parcialmente um ensaio há uns 2 meses, e simplesmente não conseguia acreditar no que via e ouvia ontem. O desenvolvimento desses alunos foi um verdadeiro milagre. Todos, sem exceção, tiveram uma dicção extraordinária, falando alto, claro e firme. As entradas estavam com um sincronismo fantástico, revelando sensibilidade social para ouvir o outro e saber quando é chegado o momento preciso de se falar. A desenvoltura perante o público foi total, eles realmente pareciam imersos em seus papéis, sem nenhum nervosismo.

Notei, e depois confirmei em conversa com a instrutora, a distribuição terapêutica das falas. Por exemplo, uma menina que antes "era" normalmente extremamente tímida e da qual se tinha dificuldade de entender na vida diária o que falava, de vez em quando gritava para um outro ator: "Cale a boca". Um outro aluno tinha antes dificuldade de falar, ainda estava com aparelho ortodôntico e assim mesmo sua fala foi ótima, podendo-se entender tudo o que dizia.

Fiquei impressionado com o desenvolvimento histriônico dos atores. Alguns até mostraram que talvez tivessem futuro numa carreira teatral. Nessa peça foram ingeridos vários trechos de autores famosos, como Sheakespeare, Tchekhov, Garcia Lorca,

\footnotetext{
${ }^{2}$ Normalmente as peças encenadas pelo grupo eram lidas, porém nessa ocasião a peça foi encenada de cor.
} 
Vinícius de Morais, etc. Os alunos leram durante as aulas essas peças ou poesias, de modo que entraram em contato com algo da literatura dramática; provavelmente isso os fez interessar-se por ela e por teatro - aposto que alguns, se não todos, jamais tinham ido a um teatro antes...

A intenção da disciplina era contribuir para a formação ampla dos alunos, e produzir neles um desenvolvimento pessoal útil para sua vida profissional. De fato, nossos cursos são totalmente intelectuais abstratos, e com isso estamos de certa maneira deformando nossos alunos, que não são simplesmente cérebros ambulantes como os tratamos. Atividades artísticas podem ser um complemento necessário para formarmos gente de um ponto de vista mais amplo, pois exigem um pensamento não-formal e desenvolvem a sensibilidade e os sentimentos. Em particular, o teatro desenvolve sensibilidade e responsabilidade sociais, capacidade de expressar emoções e de se expressar oralmente, trabalho em equipe, criatividade, etc. - tudo aquilo que falta normalmente em nossos cursos.

Tive a impressão de que esses objetivos foram alcançados e talvez até suplantados, graças à dedicação de Da. Jolanda e dos alunos, que tiveram algo que praticamente não damos a eles em nossos cursos: uma vivência positiva extraordinária, profunda, que certamente os acompanhará por toda a vida e os fará lembrar com carinho de nosso instituto. Em particular, aposto que agora esses rapazes e moças vão conseguir vender qualquer coisa, convencer qualquer cliente... Pode-se imaginar o que teria significado para eles esse desenvolvimento pessoal se fossem ser professores em sua vida profissional.

Foi uma única experiência, e isso não prova que uma disciplina de Leitura Dramática seja algo realmente útil para qualquer formação universitária. Mas, pelo menos, mostrou o que pode acontecer de positivo em uma disciplina dessas. Obviamente, a alma do negócio é o instrutor, e nesse caso os alunos tiveram a felicidade fantástica de ter uma pessoa excepcional como Da. Jolanda ministrando a disciplina.

(em email enviado em 23/03/2001)"

\subsubsection{Dojo e Teatro Fórum}

Há um tempo tivemos na empresa um treinamento sobre Feedback. Uma das atividades da tarde foi criarmos encenações onde o líder deveria conversar com um subordinado e dar feedback sobre um determinado acontecimento (por exemplo, não cumprimento de meta, comportamento inadequado, etc.). Duas coisas estavam sendo trabalhadas: de um lado o "ator" no papel de líder estava simulando uma situação real e aprendendo a lidar com situações difíceis do dia-a-dia de forma lúdica. Do outro estava a plateia, que podia (se) observar de fora. Podemos considerar essa 


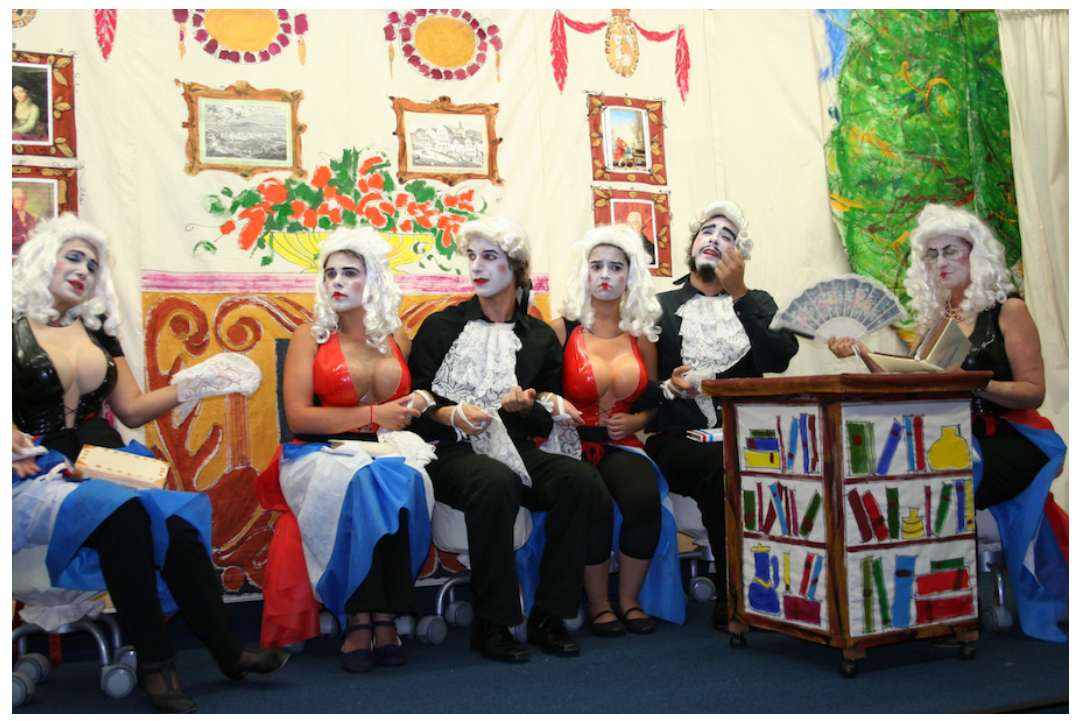

Figura 4.1: Encenação da peça "As Eruditas" por alunos de Ciência da Computação no IME-USP

observação fundamental e valiosa para o aprendizado. Ao observar o outro (e suas reações) numa situação que já vivemos, podemos extrair novas saídas, novos comportamentos possíveis.

Na mesma semana do "curso de Feedback" realizamos uma sessão de Dojo [SCB08] com os líderes de tecnologia. O Dojo (http://codingdojo.org) é um encontro de programadores que se reúnem para trabalhar em cima de um determinado desafio de programação. Eles estão lá para se divertir e melhorar suas habilidades através da prática "deliberada". Existe uma diferença entre a experiência que ganhamos no cotidiano do trabalho e o aprendizado buscado por livre vontade. Esse exercício é uma grande oportunidade de aprender com os outros. É também uma oportunidade de Simplesmente Fazer ${ }^{3}$. Só fazendo é que o programador tem a oportunidade de aprender. Podemos ler vários livros ou artigos sobre Desenvolvimento Guiado por Testes (TDD) [Bec03], mas nunca saberemos o que TDD realmente significa se não o fizermos e praticarmos repetidas vezes.

No Dojo existem algumas regras rígidas a serem seguidas (e fundamentais para a eficácia do aprendizado). Seguindo essas regras, o grupo pode observar cada programador trabalhando e depois sugerir melhorias, num processo de feedback. É a prática contínua misturada com a observação que traz o aprendizado. Durante o exercício, dois programadores formam um par e trabalham em cima do código, enquanto a plateia observa em silêncio. Mesmo que a dupla esteja fazendo coisas muito erradas e absurdas, a regra é observar e só depois que os testes estiverem

\footnotetext{
${ }^{3}$ Vide Seção 2.5.1.
} 
passando comentar. Além de tudo, é um grande exercício de disciplina (bons programadores só são bons porque têm muita disciplina). A cada 7 minutos troca-se uma pessoa da dupla, de forma que todos tenham a oportunidade de programar. No momento da troca fica claro como um código mal feito do passado pode atrapalhar um trabalho futuro. Outro fato evidente é ver os vários estilos de programação e como uma comunicação ineficiente dentro do time pode levar a resultados completamente improdutivos e muitas vezes desastrosos.

Claro que a troca não é o principal fator que faz com que código ruim do passado seja difícil de manter no futuro. O código ruim em si é que é o problema. Um mesmo programador pode pegar um código seu do passado e não conseguir fazer nada com ele a não ser rescrevê-lo do zero, de tão calamitoso que estava. É interessante observar como é importante sempre escrever um código mínimo mas que, ao mesmo tempo, deixe espaço para evolução sem muito custo. Esse é o desafio. Muitas rodadas acabam focando mais nas discussões sobre qual seria o melhor código do que observar a dupla codificando.

A vivência do Dojo pode ser encarada como uma experiência teatral. A princípio, o termo "teatro" pode significar um lugar, um prédio onde acontecem representações teatrais. Mas teatro também pode ser apenas qualquer lugar onde coisas acontecem sob a vista de espectadores "paralisados". Em Jogos para Atores e Não Atores [Boa98], Augusto Boal afirma que

"no sentido mais arcaico do termo, teatro é a capacidade dos seres humanos (ausente nos animais) de se observarem a si mesmos em ação. Todos os seres humanos são atores - porque atuam - e espectadores - porque observam. Somos todos 'espect-atores'."

Existe uma forma de teatro criada por Augusto Boal e o grupo Teatro dos Oprimidos chamada "Teatro Fórum". Essa forma foi muito difundida na Europa na década de 1980 e consiste, inicialmente, num problema real que é apresentado como espetáculo teatral. Em seguida, os espectadores são convidados a entrar em cena, substituir o personagem "oprimido" na situação encenada (personagem que luta para transformar a sua realidade) e, através da improvisação, apresentar alternativas que mudem o rumo dos acontecimentos. O público, através da observação, é então capaz de tirar conclusões que podem servir de gatilho para aprimoramentos em suas vidas individuais.

É claro que existe uma grande diferença entre a resolução de um problema humano e psicológico (razão pela qual o Teatro dos Oprimidos foi criado) e a resolução de problemas matemáticocomputacionais. Mas mesmo na solução de questões algorítmicas complexas existem pessoas realizando um trabalho. Se o problema tiver que ser resolvido por várias pessoas, é preciso existir muita qualidade na comunicação. Ainda mais quando participarem pessoas de diferentes níveis de maturidade. Cada um poderá resolver a questão de forma diferente, mas todos precisam aprender com o processo. Ver o outro errar ou acertar é uma forma de reconhecer as próprias limitações ou habilidades. Ao mesmo tempo em que o Teatro (e o Dojo) nos expõe individualmente, ele traz à 
tona oportunidades de aperfeiçoar e ampliar nosso conhecimento.

Podemos encarar a dupla do Dojo como dois atores que estão representando personagens de programadores; um programador também pode ser visto como um personagem. Ele pode ser nervoso, inquieto, ansioso, calmo, empolgado, rápido, egoísta, desanimado: todas características humanas e que podem mudar com o tempo (num dia, o programador está ansioso, no outro ele está calmo). Como lidar com todas essas emoções no dia-a-dia de forma hábil?

A plateia numa sessão de Dojo é como o público no teatro, que observa as reações e comportamentos das personagens. Não há forma melhor de aprendermos a lidar com situações inusitadas senão vivendo-as e observando-as. Mas para vivê-las e querer observar é preciso encarar nossas deficiências e respeitá-las, e saber que com trabalho e muita prática podemos melhorar sempre.

\subsubsection{Depoimentos dos alunos de leitura dramática no IME-USP}

No final de cada curso de Leitura Dramática, a professora solicita aos alunos que escrevam um pequeno depoimento sobre suas experiências pessoais no semestre. Tivemos acesso a esses depoimentos e extraímos alguns trechos que consideramos relevantes. Nosso objetivo foi mostrar como esse tipo de vivência pode trazer enormes benefícios, tanto para a vida acadêmica, quanto para a vida profissional e pessoal do aluno. Esses depoimentos são palavras dos próprios alunos.

Além desses depoimentos, fizemos algumas entrevistas (vide Seção 4.1.3) com alguns antigos alunos do curso de teatro no IME-USP. Nas entrevistas, também observamos as mudanças positivas na qualidade de vida dos alunos. Fizemos as mesmas perguntas básicas para alguns alunos e resumimos as respostas.

Após os depoimentos e entrevistas, na Seção 4.1.4, apresentamos uma pesquisa com um grupo de 46 alunos escolhidos aleatoriamente. Todos eles cursaram a disciplina de Leitura Dramática entre 2002 e 2008.

Seguem, então, primeiramente, os depoimentos escritos dos alunos, alguns apresentados de forma anônima:

"Foi muito bom frequentar tal curso, aprendi a dar mais atenção a mim mesmo a enxergar melhor a importância dos meus movimentos e da minha postura. Agora, sinto que posso expressar e controlar melhor as minhas sensações, no início do curso diria que tudo não passava de um divertimento, uma brincadeira, mas agora vejo a diferença que todo esse processo realizou em mim." (Anônimo)

"Precisávamos de um choque, algo que nos tirasse da inércia em que as aulas do IME nos colocaram. Nós não falávamos, nem quando queríamos ser ouvidos, não sabíamos nos portar e, acredite, também não sabíamos respirar! A ginástica, ioga ou relaxamento do início das aulas nos chacoalhava e nos tirava da tal inércia. Nos punha em movimento, nos ensinava nossos próprios 
corpos e criava uma interação entre nós. Aprendíamos a nos portar diante das pessoas para nos sentirmos seguros e aprendíamos a conhecer, controlar e tirar proveito de nossas emoções. E isso tudo apenas no início das aulas. A professora cumpriria ainda uma missão muito mais difícil: aprenderíamos com ela a compreender um texto além daquilo que estava escrito, aprenderíamos a brincar com a imaginação e com a criatividade e finalmente, aprenderíamos a falar, de forma clara e cativante, para que nos ouvissem e nos dessem ouvidos. Tivemos ótimos exemplos de antes e depois. No início do curso, uma colega só iria à frente para falar se fosse coagida para tanto e, estando lá, não se ouvia o que dizia mesmo estando ao seu lado. Quase no final do curso, quando solicitado que falássemos sobre o que achamos do curso, ela se levantou e falou sua opinião, para todos ouvirem. Enfim, eu adorei o curso. A ponto de considerá-lo indispensável. Ele corrige problemas de postura e comportamento que eu vi em mim, nos colegas e nos professores do instituto. Fica, então, a minha sugestão: que o curso seja obrigatório para alunos e professores, no início e final da graduação." (Anônimo)

"Essa matéria foi uma das (ou a única) que mais me ensinaram algo como ser humano, algo que levarei para toda minha vida. Me ajudou a superar tabus e alguns preconceitos, ou pelo menos me ajudou a enfrentá-los. Além disso, me aproximou de outras áreas do conhecimento que são muito importantes para a formação de qualquer pessoa." (Luiz Cláudio)

"O curso foi bastante útil na medida em que serviu-me para atentar-me à minha respiração e muito mais útil em relação a sociabilidade. Foi bom para expressar o que sinto para as outras pessoas. Sinto que, embora ainda não seja ideal, uma evolução em minha empostação vocal. Considerando o fato de estar no IME, acho esse curso fundamental e essencial para todos os alunos, embora nem todos concordem que isso seja importante" (Anônimo)

\section{Mapa de Carnough}

(Ricardo Augusto Fernandes)

Sinto-me máquina,

Sinto-me com a estupidez de uma máquina,

Tão longe das coisas tão fáceis,

Tão fáceis, as coisas do tempo,

Do espaço,

Do ser ou não ser.

Que Shakespeare me desculpe,

Pois Ah! se o difícil fosse ser ou não ser...

Seria tão simples quanto Boole, 
Ser ou não ser mil vezes!

Infinitobytes de soluções.

Mas não! tenho de ser e não ser,

Estar e não estar,

To be and not to be.

Não há lógica nos humanos.

Tão analógicos... e tão belos...

E eu tão errado... ou tão certo,

Ou Zero... ou Um.

\subsubsection{Entrevistas}

Entrevistamos alguns alunos que participaram do curso de leitura dramática no IME. A maioria participou da disciplina uma única vez e fez pelo menos uma montagem teatral junto com os colegas. Todos eles demonstraram terem obtido grandes benefícios por terem passado por essa experiência.

\section{- Como foi para você ter feito Leitura Dramática?}

- Sempre gostei de alegrar as pessoas. O que atraiu foi o caráter teatral, lúdico. Tive a oportunidade de trabalhar o lado artístico. Jolanda é uma pessoa e professora fantástica, ela sabe como tirar o máximo da pessoa. Ela sabe o que está fazendo, de forma que o aluno não percebe o processo de mudança.

- Comecei a usar naturalmente técnicas da disciplina para falar em público, pronunciar melhor as palavras. Aprendi a respirar. Consegui aprender a controlar o timing e prender a atenção do público. Isso é sutil. Precisa "cair a ficha" que isso existe. Nem muito rápido nem muito lento. No tempo certo.

- Comecei a ter mais desenvoltura para falar em público. Melhorou o meu lado social, ao interagir com pessoas diferentes, ter mais contato com outras pessoas. Também era um "Stress release". Algo diferente e prazeroso, imperdível, não queria deixar de ir. Comecei a participar mais das outras aulas, fazer mais perguntas. Tive mais amizades após o teatro.

- Conheci novos modos de abordar as pessoas, falar a mesma coisa em vários tons pode ter vários significados. Descobri a importância do lado humano e da comunicação. Minha comunicação com as pessoas melhorou e eu me aproximei mais das pessoas. Tive a oportunidade de conhecer mais sobre o Teatro em si. Abriu uma nova faceta - conciliar 
a vida profissional com a artística e abriu a possibilidade de aflorar algo de Arte que eu já tinha e que estava adormecido.

- Qual a diferença entre um curso de teatro no IME e qualquer outro curso de teatro? O que é especial para os alunos de Computação?

- Saber se expressar de maneira dramática, coisa que aluno do IME não sabe fazer, na maioria das vezes. Ler é fácil. Colocar um sentimento e intenção na palavra é bem diferente. Pelo caráter racional do ambiente, do mundo abstrato em que alunos de exatas vivem, é fácil se desconectar do ser humano, do que a pessoa precisa. Depois que eu fiz o curso, amigas minhas me falaram que nossas conversas melhoraram. Ao aprender a colocar drama, sentimento nas palavras, você começa a se preocupar mais com o ser humano que está do seu lado e não alguém que é mais um número. Com cada pessoa tem que se falar de forma diferente. O curso ajuda a se expressar em público com sentimento.

- O IME é um isolamento de cultura, não tem cultura, só técnica, só teoria, teoria, teoria pura. O teatro é diferente, é humano, não tem isso no IME. A teoria distancia do lado humano. Traz de volta a realidade humana, afinal somos humanos e temos que interagir com pessoas o tempo todo. O aluno precisa de algo diferente, senão acaba louco. Na matemática não tem contestação. Tudo é provado. O dia-a-dia, o ser humano não tem exatidão. Você tem que interagir com as pessoas. Se você não interage, você se isola como um animal num canto. Isso é descartável no mercado de hoje, não é isso que as empresas procuram. Elas procuram pessoas criativas, que saibam lidar com outras pessoas. As vezes, é mais importante atender bem um cliente do que ter uma boa solução técnica.

- O computador isola, induz ao individualismo. O teatro incentiva a interação humana, recoloca as pessoas em contato.

\section{- Existe um trabalho corporal envolvido nessa disciplina?}

- Quando se coloca sentimento na palavra se percebe que se tem um corpo. A mente não serve só para provar teorema e escrever algoritmos. Ela está conectada com um corpo que tem necessidades. Com o teatro, tomei consciência de que minha postura em público era ruim. As palavras têm que concordar com o resto do corpo.

- Quando se pede para o aluno imaginar que uma mesa não é uma mesa, o aluno imagina que a mesa é um computador, um teclado. 
- Exercícios entre rapazes e moças são tabus. Os homens não sabem como agir, usar o corpo para chamar atenção, seduzir.

- Acho importantíssimo o trabalho do corpo. Melhorei minha postura ao sentar, ao conversar, a forma de gesticular. Me ajudou no emprego de consultor, no trabalho de inspirar confiança no cliente. Aprendi a importância do apoio no chão ao falar. Isso eu apliquei na prática e hoje se tornou natural. Todo exercício físico libera stress e melhora como pessoa.

- Deve existir um equilíbrio. Não se pode ser $100 \%$ corpo nem $100 \%$ cabeça. O contato físico trouxe para os alunos a possibilidade de viver experiências até então desconhecidas.

- Quais seriam os pontos negativos ou prejudiciais do Teatro na Computação? Os alunos perdem o foco?

- O ser humano precisa de atividade social, aprender a lidar de forma consciente com o lado humano. A vida é a teoria da professora vista na prática.

- Isso é polêmico: alguém que não tem noção do seu lado humano passa a ter. Perfil dos alunos: desconectados da sexualidade. O teatro força o contato com a própria sexualidade. Alguns alunos podem se ofender com essa forma.

- Interagir no desenvolvimento de software minimiza vícios de programação. Contato humano promove troca de conhecimento. Algumas pessoas não querem interagir, nem expor seu conhecimento. Preferem viver isoladamente.

- Quais os resultados nas pessoas que você conhece? Você tem amigos que fizeram a disciplina? O que você viu mudar nessas pessoas?

- No começo a disciplina chamou atenção dessas pessoas porque dava créditos. Depois elas perceberam que realmente agregava um conhecimento que não havia em nenhuma outra disciplina de exatas. O meio (no caso o IME) onde é lecionada PRECISA desse tipo de conhecimento e de prática. Há uma certa falta de tato social dos alunos. A disciplina aproxima as pessoas.

- Certamente, algumas pessoas ganharam desenvoltura. Tenho uma colega, que tinha medo de falar com as pessoas. Depois do curso, mudou bastante e ela mesmo reconheceu isso. Melhorou o volume da voz.

- Um quarto das pessoas só fazem a disciplina pelo crédito. Três quartos não enxergam o potencial da disciplina. Eu fiz a disciplina várias vezes, mas nunca terminei. Só fazia por gosto mesmo. 
- Ricardo tinha banda, mas tinha parado. Pôde retomar o perfil artístico que já era nato. Hoje canta no coral. A pessoa descobre capacidades acima do mundo acadêmico.

- Uma colega tinha o corpo curvado para frente. Depois do curso ela descobriu que tinha um corpo e melhorou muito sua postura. O ser humano tem problemas de auto conhecimento. A pessoa descobre que tem voz algumas vezes.

- Um amigo que era um típico nerd começou a falar e se expressar mais.

\section{- Você acha que a disciplina deveria ser obrigatória?}

- Sim, mas em que departamento? A disciplina entrou graças ao professor Setzer, que insistiu para que os alunos soubessem dela. O IME não percebeu a importância dessa disciplina. As pessoas precisam trabalhar o lado humano-artístico. Poderia sair uma matéria obrigatória não tão importante e entrar essa. Mas existe muita burocracia e existe um preconceito das pessoas. Antes de programar, ele é ser humano, tem vontades, gostos.

- Deveria ter alguma coisa, mas não obrigar as pessoas a fazer o que elas não querem. Alguns alunos jamais fariam, ou fariam a contra-gosto.

- A Arte é para ser apreciada, mas não necessariamente aprendida. Precisa gostar. Para ter criatividade é preciso antes gostar. Pelo menos música todo mundo gosta. Existem diferentes tipos de expressão. Alguns não fariam teatro, mas gostam de desenhar, ou são músicos.

- Tem pessoas que gostam de teatro para assistir. Talvez não devesse existir uma disciplina obrigatória, mas a obrigatoriedade de fazer alguma coisa na área artística. Isso seria essencial! Alguma prática esportiva deveria ser obrigatória. Isso é essencial. Um conjunto de disciplinas artísticas para o aluno optar por uma delas.

\section{- Não existem pessoas no IME com esse lado mais humano?}

- São poucos, sempre os mesmos, figuras ilustres pontuais. A maioria das pessoas anda olhando para o chão.

- Nerds não tem namorada não possuem necessidade de contato social.

- Qual a diferença entre brincar de ser outra pessoa num chat e ser um personagem no teatro?

- No teatro todo mundo está vendo quem é a pessoa. Empresta-se o corpo para passar uma ideia, um personagem, não há enganação. No virtual pode-se enganar, iludir, mas é tudo mentira. 
- Ao vivo podemos mostrar alegria, empatia. Se você contar uma piada pelo MSN não vai ter tanta graça. Ao vivo é que se percebe o sentimento da outra pessoa, é mais marcante, é mais real!

\section{- A disciplina de leitura dramática trabalha com a sexualidade?}

- Sim, porque é interação humana. Para arrumar uma namorada é preciso interagir com mulheres. As mulheres tem o lado humano mais aflorado e natural. Em teoria, o aluno que fizer leitura dramática tem mais chances de arrumar uma namorada. Na prática também. Ele tem que interagir fisicamente na aula.

- Ele se vê, num momento de brincadeira, em uma situação até então inédita em sua vida. A partir daquela primeira vivência quebra-se o tabu e aquilo passa a ser natural e ele pode levar essa experiência para a vida.

- Depois de um exercício com uma pessoa do sexo oposto, o aluno passa a ter uma pessoa com quem ele encontra, conversa nos corredores.

\section{- Defina a disciplina com uma frase curta}

- A disciplina ajuda alunos a descobrir que acima de tudo existe o ser humano.

- A matemática surgiu da filosofia.

- Foi uma salvação de uma realidade cruel. Ver que existe vida lá fora.

- O teatro trouxe otimismo para a vida.

- Como transmitir uma ideia de forma eficiente.

- A disciplina coloca os pés no chão, mostra que a vida é mais do que um monte de contas.

- Defina a disciplina com uma única palavra

- VIVÊNCIA

- SALVAÇÃO

- PRAZER

\subsubsection{Pesquisa}

Desde 2003, por volta de 200 alunos já participaram do curso de Leitura Dramática no IME. Fizemos um levantamento de todos os emails dos alunos que participaram da disciplina. Enviamos uma mensagem solicitando a eles que preenchessem um formulário online ${ }^{4} \mathrm{com}$ as perguntas abaixo.

${ }^{4}$ Utilizando a ferramenta Google Forms. 
Quarenta e seis responderam o questionário ${ }^{5}$. Após compilarmos as respostas, chegamos a algumas conclusões interessantes. Seguem as perguntas feitas aos alunos:

1. Qual sua opinião sobre ter cursado Leitura Dramática?
a) Gostou demais
b) Gostou um pouco
c) Neutro
d) Não gostou
e) Não gostou nada

2. Sobre mudanças que o curso trouxe para sua vida
a) Mudou completamente para mim
b) Mudou bastante para mim
c) Mudou pouco para mim
d) Não mudou nada para mim

3. Existe diferença entre um curso de teatro para Computação e um curso de teatro normal?
a) $\operatorname{Sim}$
b) Não

4. Você acha que a disciplina deveria fazer parte do currículo do curso de Computação como obrigatória?
a) Com certeza sim
b) Talvez
c) Com certeza não

5. Você hoje pratica algum tipo de atividade artística?
a) Música
b) Dança
c) Teatro
d) Pintura

\footnotetext{
${ }^{5}$ Como os emails eram de anos passados, não tínhamos como garantir quem realmente receberia o questionário ou não
} 
e) Desenho

f) Nenhuma

6. Que outra disciplina artística você acha que seria interessante incluir no currículo da Computação?
a) Dança
b) Música
c) Pintura
d) Desenho
e) Nenhuma

7. O Curso incentivou para que você começasse com alguma dessas atividades?
a) $\operatorname{Sim}$
b) Talvez
c) Não

8. Qual a importância da Arte na vida de alguém da Computação?
a) Extremamente importante
b) Importante
c) Neutro
d) Pouco importante
e) Nada importante

9. Você recomendaria a algum colega cursar essa disciplina?
a) Com certeza
b) Talvez
c) Jamais recomendaria

10. Você cursou a disciplina por que razões?
a) Créditos
b) Gosta de teatro
c) Gosta da professora 


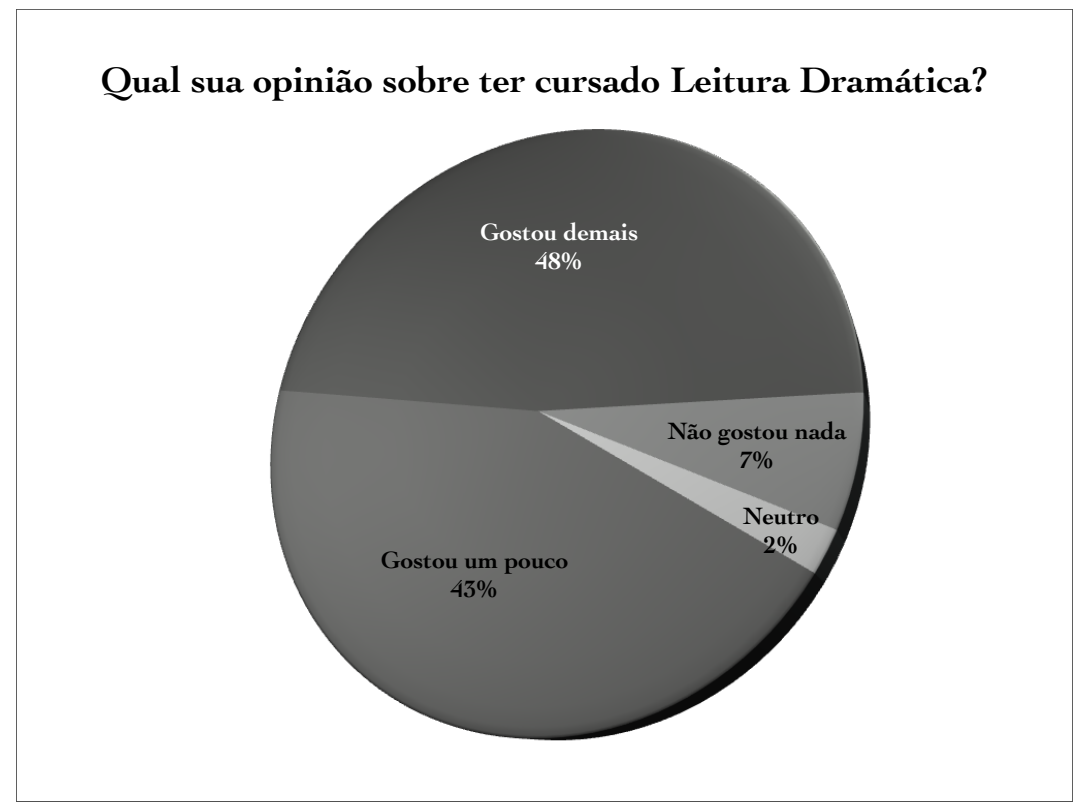

Figura 4.2: Satisfação dos alunos de Computação de terem cursado Leitura Dramática

d) Recomendação

e) Fugir um pouco das disciplinas tradicionais

f) Ter conhecimento em alguma outra área

g) Acha que a disciplina é importante para sua formação

h) Outra razão? Qual?

Como pode ser visto na Figura 4.2, apenas 7\% dos alunos não gostaram de ter feito a disciplina. Um aluno (2\%) teve opinião neutra e a grande maioria (91\%) gostou do curso. Na Figura 4.3, vemos que $72 \%$ dos alunos acredita que tiveram algum tipo de mudança para melhor em suas vidas após cursarem Leitura Dramática. Menos de um terço dos alunos (28\%) disse que o curso não mudou em nada suas vidas e nenhum pesquisado respondeu que o curso mudou sua vida para pior.

Quase todos os pesquisados (41 alunos) disseram que há diferença entre um curso de teatro para alunos da Computação e um curso de teatro normal (Figura 4.4). Talvez isso mostre que os próprios alunos têm consciência de que o seu meio tende muito para o lado exato do ser humano e que um curso de teatro para esses alunos de exatas têm um impacto muito significativo.

A Figura 4.5 mostra que pouco mais da metade (52\%) dos alunos acha que a disciplina não deveria ser obrigatória no currículo da Computação, enquanto que $30 \%$ acha que talvez devesse ser 
Sobre mudanças que o curso trouxe para a sua vida

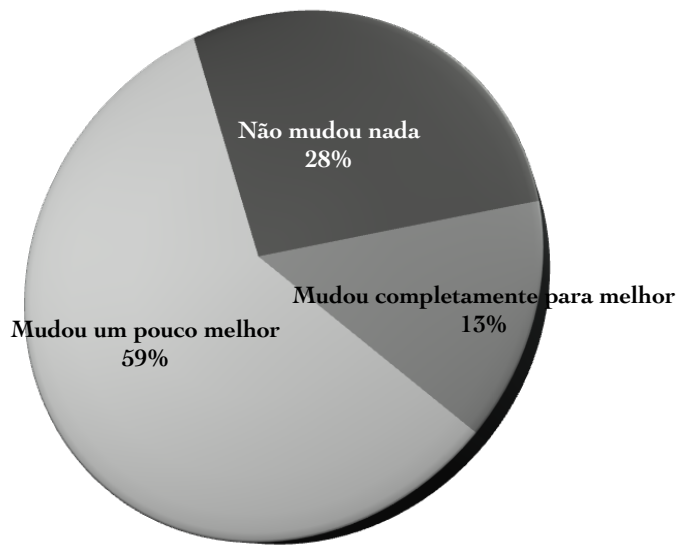

Figura 4.3: Mudanças que o curso trouxe para a vida dos alunos

obrigatória e 17\% acredita que a matéria deveria com certeza pertencer à grade curricular do curso de Computação.

Quando perguntamos se a Arte era importante para a vida dos alunos na área da Computação (Figura 4.6), 48\% disseram ser extremamente importante e 37\% disseram ser importante. $11 \%$ dos entrevistados disseram que a Arte tem importância neutra. Apenas $4 \%$ disseram que a Arte é pouco importante na vida de alunos de Computação.

Ao questionarmos se os alunos recomendariam a seus colegas que cursassem a disciplina (Figura 4.7), $70 \%$ disseram que recomendariam com certeza. Outros $24 \%$ disseram que talvez recomendariam e apenas $6 \%$ não recomendariam de forma alguma.

Deixamos os alunos livres para preencherem quais atividades artísticas eles praticavam regularmente. Observamos que 37\% dos alunos não praticam nenhum tipo de atividade artística. Dos que praticam, a extrema maioria das atividades (43\%) é relacionada à música (Figura 4.8). Outras atividades citadas, porém com menos relevância, foram dança, desenho e teatro. Alguns entrevistados fizeram questão de responder que praticavam algum tipo de esporte. 


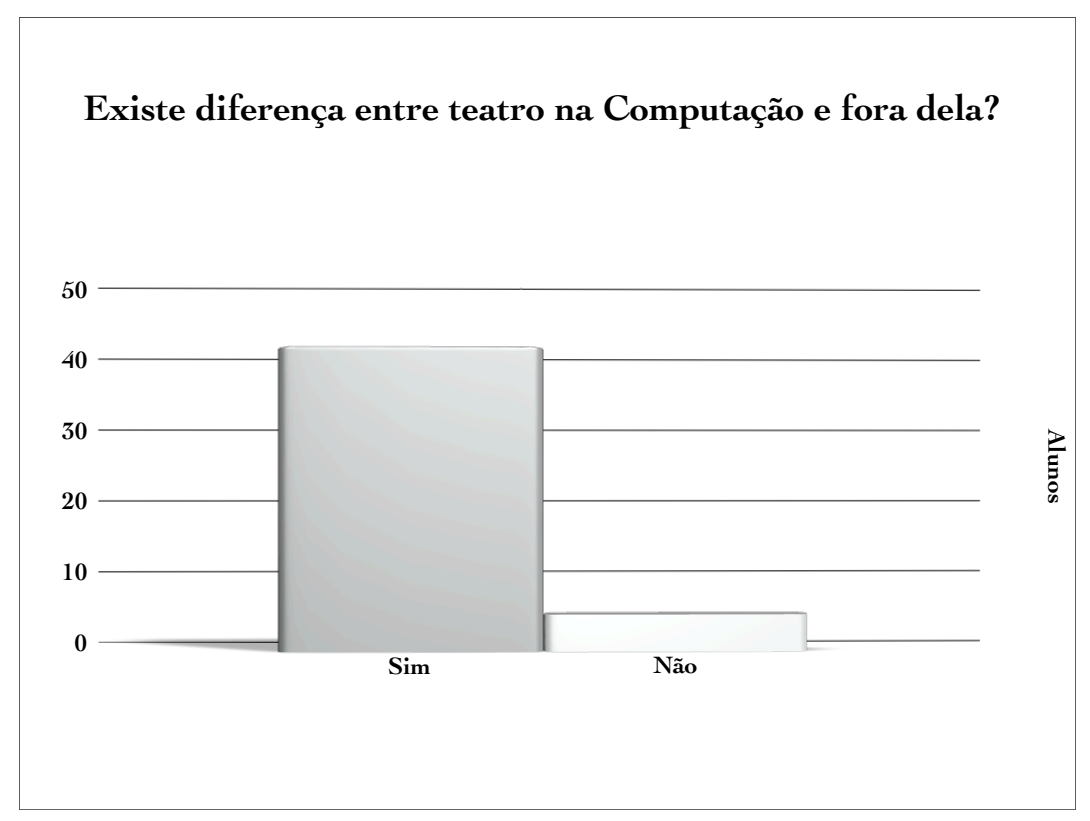

Figura 4.4: Existe diferença entre um curso de teatro para Computação e um curso de teatro normal

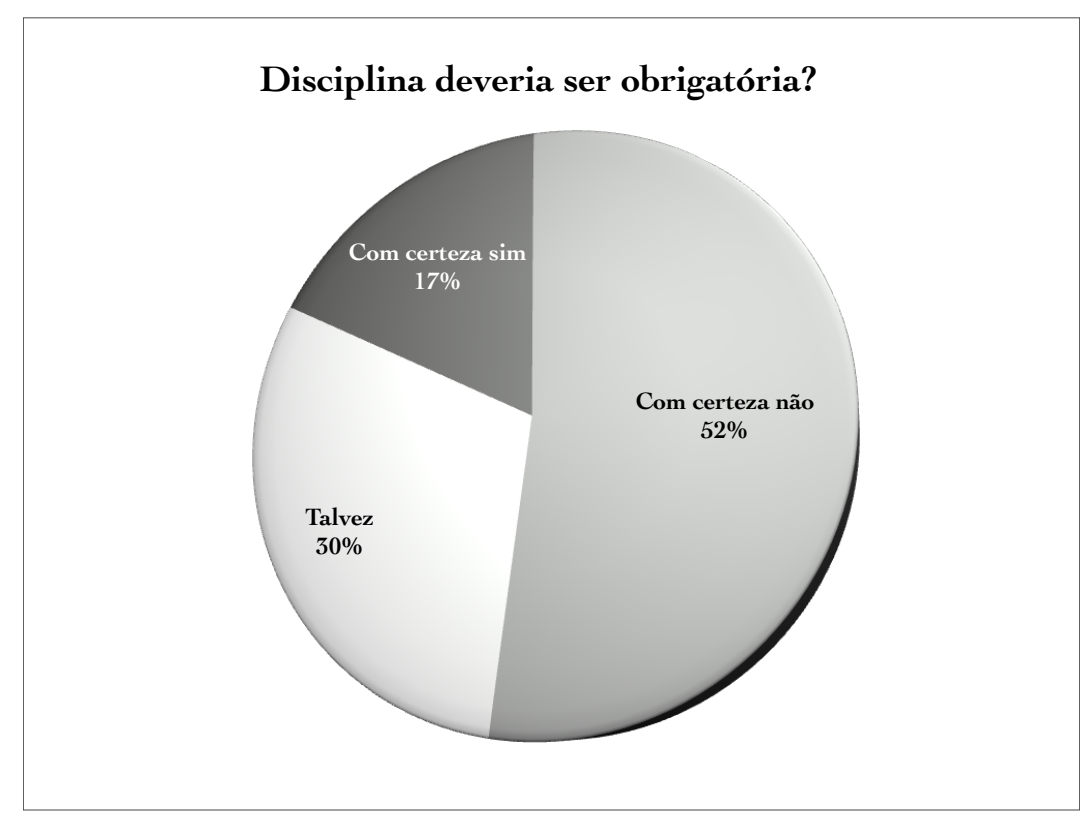

Figura 4.5: Os alunos acham que Leitura Dramática deveria ser obrigatória? 


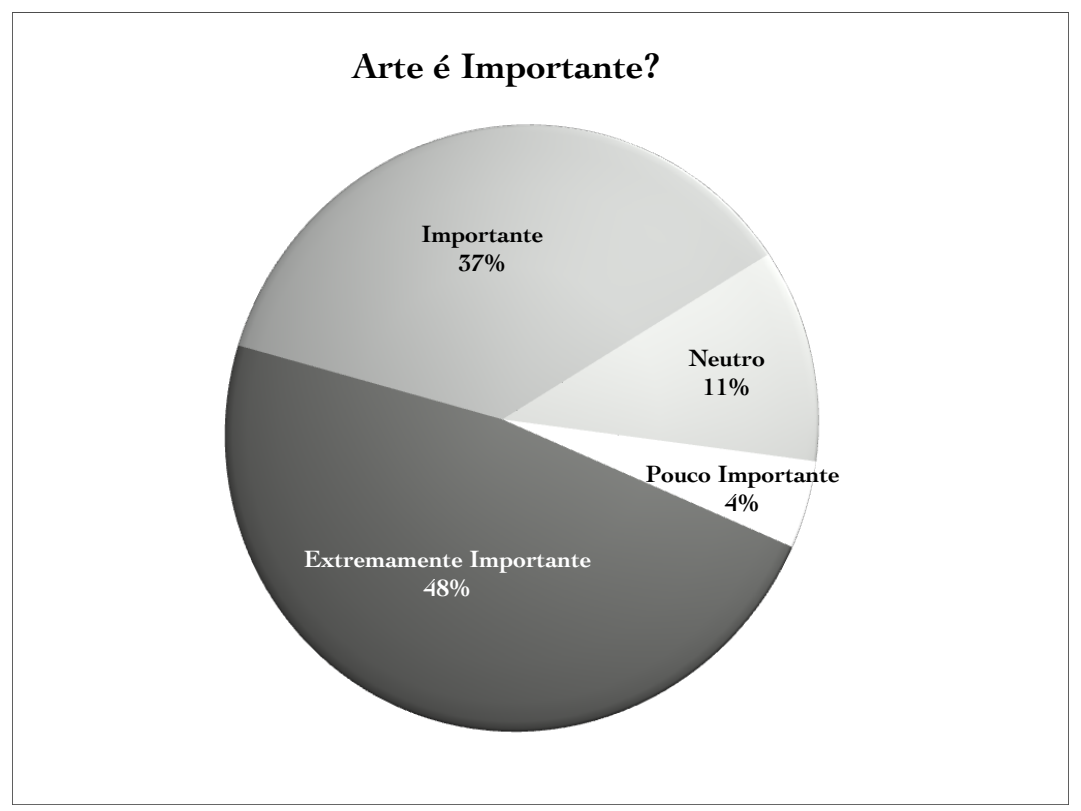

Figura 4.6: A importância da Arte para um aluno de Computação

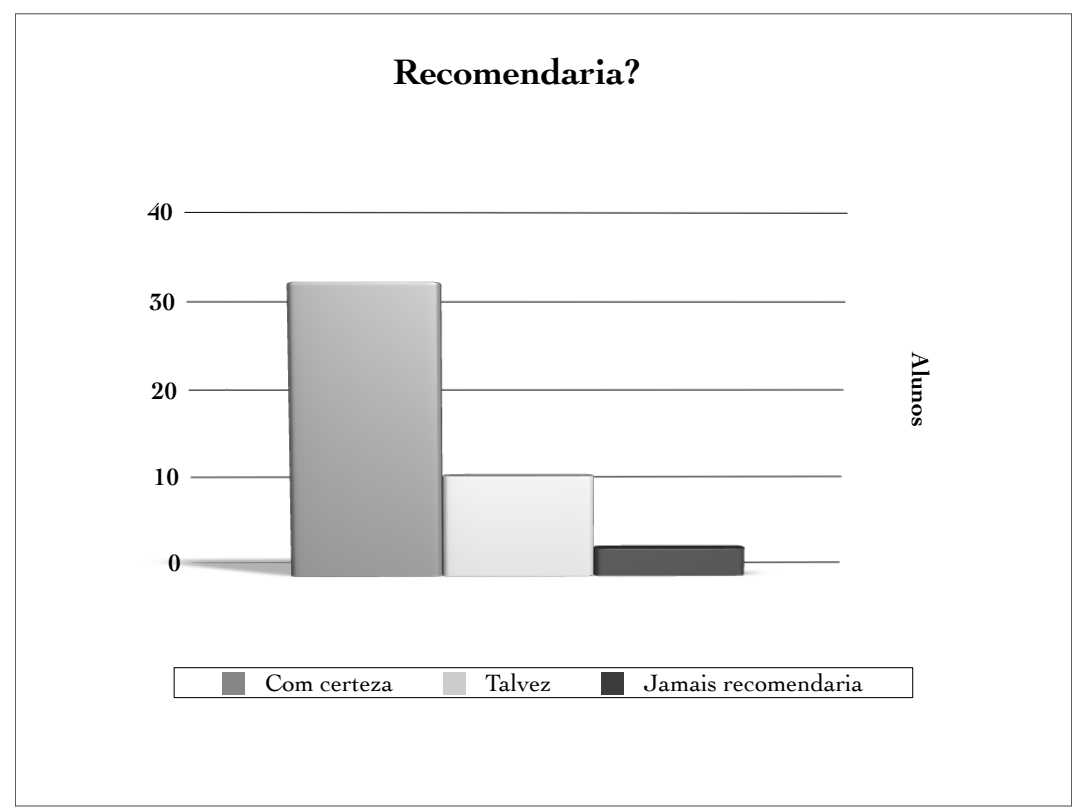

Figura 4.7: $O$ aluno recomendaria a disciplina para algum colega? 


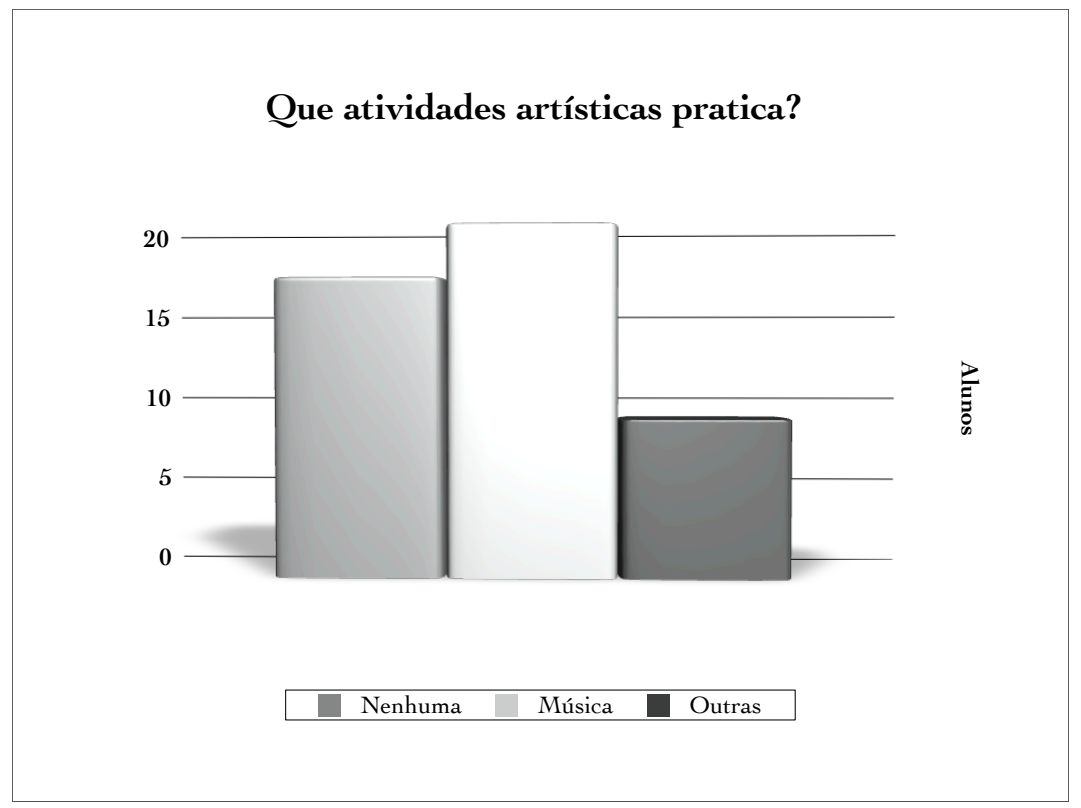

Figura 4.8: Que atividades artísticas são praticadas pelos alunos?

\subsubsection{Proposta de aprendizado técnico usando dramaturgia}

Uma das melhores formas de se aprender sobre um determinado assunto é vivenciando situações nas quais o assunto a ser absorvido está inserido. Isso quer dizer que, ao invés de expormos conceitos no formato padrão de palestras ou seminários, vamos propor uma nova forma de aprendizado usando o teatro e a dramaturgia.

Por exemplo, ao tentar ensinar sobre Padrões para Introduzir Novas Ideias, não vamos simplesmente falar sobre os padrões e explicar tecnicamente como eles são. Vamos construir uma história real, um roteiro, onde existirão personagens que representarão cenas do dia-a-dia. Nas histórias em que esses personagens estão inseridos acontecerão situações que mostrarão claramente como os padrões acontecem. O público não receberá uma explicação sobre o padrão: ele verá uma história natural em que o padrão está inserido.

Uma abordagem ainda mais interessante é aquela em que o próprio público é convidado para representar os personagens dessa história. Podemos escolher no público uma pessoa para representar o Inovador, uma para representar o Evangelista, outra para o Guru e assim por diante. As pessoas que representarão os papéis viverão na pele esses personagens. Essa experiência será inesquecível e o entendimento sobre o assunto será muito mais visceral e intenso.

Temos aqui uma proposta de roteiro teatral para o aprendizado de Padrões para Introduzir 
Novas Ideias. Esse roteiro foi inicialmente escrito em Inglês por Linda Rising e pela Mary Linn Manns. Ele não aparece no livro, mas vem sendo usado pelas autoras (que nos cederam o material) em algumas Oficinas, para ensinar Padrões para Introduzir Novas Ideias. O roteiro foi adaptado para a língua portuguesa e para a realidade da cultura brasileira. 


\section{Roteiro teatral: Padrões para Introduzir Novas Ideias}

\section{Cena 1[Introdução]}

\section{EVANGELISTA}

Sabemos que a indústria de software é muito dinâmica e novas ideias surgem a todo instante em todas as partes do mundo. Nem sempre é fácil fazer com que essas ideias sejam adotadas, pois, para isso, é preciso fazer as pessoas mudarem sua forma de pensar. Deve-se sempre considerar o fato de que o ser humano, diferente do computador, é bastante imprevisível. Mas mesmo assim, podemos encontrar determinados padrões de comportamento, que não resolvem todas as questões, mas ajudam a lidar com situações e continuar caminhando para atingir um determinado objetivo.

Trago nessa apresentação alguns exemplos dentre os 48 Padrões para Introduzir Novas Ideias compilados pela Linda Rising e Mary Linn Manns. Falta definir o que é um padrão para ter certeza que falamos a mesma língua.

Um Padrão é uma regra de três partes: um contexto, um problema que ocorre nesse contexto e uma solução para esse problema nesse contexto, isto é, um padrão é uma solução que se funcionou duas ou três vezes, provavelmente vai funcionar novamente. Quando você identifica esse padrão, você escreve e coloca num catálogo, [simpático] e torce por ele. Foi isso que Linda e Mary fizeram.

Os padrões que elas identificaram têm o objetivo de ajudar na difícil tarefa de introduzir uma nova ideia dentro de uma organização, pois se essa ideia pressupõe mudanças culturais, o trabalho é ainda mais complicado. [modéstia] Proponho ainda quatro novos padrões, modestamente identificados por mim, que podem ser incorporados ao catálogo original, mas agora vou apresentar apenas um, que é justamente a forma que eu escolhi de apresentar esse trabalho.

Nesse padrão mostro a importância de se usar atividades artísticas no dia-a-dia de pessoas que trabalham com desenvolvimento de software e como a Arte pode nos ajudar a introduzir novas ideias. Pesquisei algumas práticas artísticas e pude encontrar elementos de ligação entre o lado puramente matemático e bem definido do ser humano e o seu lado abstrato, analógico e artístico. Como diz Peter Brooks, famoso teatrólogo, "Nos dias de hoje, a tragédia da Arte é que nela não há Ciência e a tragédia da Ciência é que nela não há emoção". Desenvolver software pode ser também encarado como uma atividade de Ciências Humanas, acima da questão técnica e puramente lógica. Existem pessoas envolvidas no processo: as que usam e as que criam o software. Existe uma barreira que separa os programadores das pessoas que usam o software. Essa barreira pode ser quebrada se pessoas da Computação começarem a desenvolver, além das habilidades computacionais que já lhes são óbvias, habilidades artísticas que envolvam a compreensão daquelas emoções humanas que 
motivam as pessoas.

\section{Cena 2}

\section{EVANGELISTA}

Ano passado eu estive numa conferência muito interessante, onde ouvi falar de Métodos Ágeis! Achei a filosofia ágil tão maravilhosa que fiquei com muita vontade de implantar essa cultura na empresa onde eu trabalhava. Me tornei um Evangelista daquela novidade [Cola a plaquinha Evangelista]. Um Evangelista é aquela pessoa que se apaixona por uma ideia e espalha a novidade. Sim, porque naquela época era algo realmente novo.

\section{INOVADOR}

Coisa nova! Legal! Qualquer coisa nova eu tô dentro! Estou contigo nessa!

EVANGELISTA

[para o público] Este é o Inovador, o primeiro que você deve trazer ao seu lado. Segundo um trabalho de E.M. Rogers, ele representa 3,5\% da população. [para o Inovador] Ei! Vamos com calma! Você é apenas 3,5\% viu? A gente ainda precisa convencer todos os outros, mas seu entusiasmo já é um bom começo.

\section{INOVADOR}

Quem são os outros

\section{EVANGELISTA}

Aqui está você, o Inovador. Depois temos os que adotam cedo, que se interessam logo, mas ainda ainda são um grupo pequeno: 12,5\%. O grupo mais importante é a primeira maioria, que representa a ponte entre o velho e o novo e são 35\%. Eles são como São Tomé: precisam ver que a ideia já funcionou alguma vez antes de aceitá-la. Depois vem a Última Maioria - os heróis da resistência - que só aceitam a novidade com uma certa pressão ou só depois que todos os outros já aceitaram: são 35\%. Por último, os Retardatários, que nunca vão aceitar, e que representam 14\%.

\section{INOVADOR}

Ah, já sei. São aqueles ficam empacados no meio do caminho: "Sempre funcionou desse jeito, para que eu vou mudar?" [Ambos riem]

\section{Cena 3}

\section{EVANGELISTA}

O segundo lance é o Padrão "Faça Comida": vamos marcar um almoço e conversar com o resto da equipe para ver se eles gostariam de conhecer algumas práticas da Metodologia Ágil. 


\section{INOVADOR}

Oba! Almoço! É uma ótima oportunidade para falar com as pessoas sobre coisas novas e legais! E não esqueça do café com petit gateau que eu gosto. Melhor: nosso Encontro Técnico mensal está chegando e eles sempre estão atrás de palestrantes. E ainda pagam a conta! E dá pra pedir sobremesa de petit gateau.

EVANGELISTA

A ideia da comida funciona, não? [Cola a plaquinha Faça Comida]

INOVADOR

\section{OOOOO!}

EVANGELISTA

Então aqui está um padrão para introduzir novas ideias.

EVANGELISTA

Acho que eu vou dar uma passada no escritório do Roberto pra ver se ele pode ir também. Afinal, ele é o Guru. Com o padrão do "Guru ao Meu Lado" o resto é moleza.

INOVADOR

Legal! Mas o que é que você vai fazer para convencer ele? O cara é sempre crítico quando se trata de coisa nova.

EVANGELISTA

O fato é que as pessoas respeitam muito quando o Guru apoia uma ideia, por isso que temos que trazê-lo para o nosso lado.

INOVADOR

Você tem toda razão.

EVANGELISTA

Padrão "Guru ao Meu Lado" [Cola a plaquinha Guru ao Meu Lado] aprovado.

INOVADOR

E como é que você vai fazer para atraí-lo?

EVANGELISTA

Já sei! Vou plantar um monte de sementes: vou levar uns artigos que peguei na conferência e esse livro novo que comprei. Vou deixar esses daqui na sala do café. E vou levar umas cópias a mais para quem se interessar. [Inovador concorda entusiasticamente] [Cola a plaquinha Plantar as Sementes] 
INOVADOR

Ok, mas cuidado! Não vá pisar nos calos do Roberto. Você sabe do que eu estou falando. Esses caras mais veteranos são sensíveis e podem achar que você está querendo passá-los para trás. E também toma cuidado para não sobrecarregar o pessoal com tanta informação.

EVANGELISTA

Isso aí é um padrão: "O Suficiente" [Cola a plaquinha O Suficiente].

INOVADOR

É bom! É difícil absorver muita coisa nova de uma só vez. Não é todo mundo que tem capacidade de apreciar novidades como eu. [Evangelista com cara de achar graça. Inovador olha o quadro] E agora fazemos o que?

\section{EVANGELISTA}

Bom... agora temos que experimentar alguma prática de Desenvolvimento Ágil entre nós, antes de falar com as pessoas. Sabe como é, antes de mergulhar na piscina, é melhor experimentar a temperatura da água com a ponta do pé. É mais seguro, concorda? Então [Cola a plaquinha Experimentar as Águas]. Que tal começarmos com a Programação Pareada?

INOVADOR

Programação Pareada! Legal... Só me explica o que é e começamos já.

EVANGELISTA

Na programação pareada, duas pessoas sentam juntas num mesmo computador e começam a trabalhar em cima de algum código. Dessa forma, as ideias fluem muito bem, porque cada uma delas terá uma visão diferenciada do mesmo problema, enriquecendo e compartilhando as soluções de projeto. Sabe como é, enquanto um digita, o outro dá palpite.

INOVADOR

Entendi. Então me dá o material. [Pega o material oferecido pelo Evangelista, deixa sua placa na estante de leitura e sai lendo.]

Cena 4[Evangelista para o quadro, satisfeito,

enquanto entra o Guru.]

\section{GuRU}

Oi Daniel, gostei do que você apresentou no almoço. Tem várias coisas que eu estava pensando e queria discutir com você. Pode passar na minha mesa mais tarde?

EVANGELISTA

Oi Roberto, claro, com prazer! [Guru deixa a plaqueta Guru na estante de leitura e vai saindo] 


\section{EVANGELISTA}

[para o público]Tá vendo? Ele está afim de conversa. Pode ser mais um aliado! É claro que depois de almoçar com as pessoas e de interessá-las é preciso que eu fique disponível para conversar e esclarecer dúvidas, é óbvio. "Manter Contato" [Cola a plaquinha Manter Contato] [senta]

Cena 5

\section{EVANGELISTA}

[para o público] Eu já conversei com um Inovador e um Guru. O que eu preciso agora é experimentar Métodos Ágeis em um projeto real. [Entra pessoa que Adota Cedo 1]

\section{EVANGELISTA}

Oi Cris, fiquei sabendo que você está trabalhando no Projeto de CRM. Fiquei pensando, será que a ideia de Desenvolvimento Ágil que eu apresentei hoje poderia te ajudar?

\section{QUE ADOTA CEDO 1}

Confesso que achei interessante, mas queria entender um pouco mais como é isso na prática antes de decidir alguma coisa.

\section{EVANGELISTA}

Você poderia experimentar algumas práticas. Depois de alguns meses você vê o que aconteceu e se não gostar ou não se adaptar, volte a trabalhar do jeito que você já faz hoje.

QUE ADOTA CEDO 1

É que você sabe: na teoria, às vezes, a prática é outra.

\section{EVANGELISTA}

É só uma experiência. Digamos: 3 meses? Eu posso te ajudar a avaliar os resultados enquanto a coisa acontece.

QUE ADOTA CEDO 1

Ah bom, se você nos ajudar, então podemos fazer.

\section{EVANGELISTA}

Negócio fechado! [Cris sai, deixando a plaqueta "Que Adota Cedo" na estante de leitura] Este é o padrão "Rodada de Testes" [Cola a plaquinha Rodada de Testes] e eu acabei de conquistar uma pessoa do grupo dos que Adotam Cedo. Eles representam 12,5\% da população.

\section{Cena 6}

EVANGELISTA

Bom! [olhando para as estantes onde estão as plaquinhas de personagens] Consegui convencer três padrões de pessoas a experimentar Métodos Ágeis. Um Guru, um Inovador e uma pessoa 
do grupo dos que adotam cedo. [para o público] Ainda não é todo mundo, mas já é motivo de comemoração! Então, vamos comemorar! Rosimeire! Champagne![secretária (Conector) aparece com uma bandeja com 3 copos e serve guaraná/champagne para a banca]. Guaraná Champagne. Esse é o padrão "Comemore Pequenos Sucessos" [Cola a plaquinha Comemore Pequenos Sucessos]. [Pausa para brinde mental]

\section{EVANGELISTA}

Agora já posso ter tanta gente interessada que eu não vou conseguir dar conta de todos. Hora de usar o padrão Fórum Eletrônico para manter as pessoas informadas [Cola a plaquinha Fórum Eletrônico]. [Com entusiasmo] Vou criar um grupo de discussão sobre Métodos Ágeis no Yahoo Groups [mostra muito entusiasmo no rosto]

\section{CONECTOR}

Eu ouvi o senhor falando de uma coisa nova, esse tal de Desenvolvimento Ágil! O que é isso?

\section{EVANGELISTA}

É uma forma inovadora de criar bons programas de computador.

\section{CONECTOR}

Interessante isso! Eu estou fazendo um curso de informática...

\section{EVANGELISTA}

Bacana, e já que você conhece todo mundo aqui, me ajudaria a espalhar essa novidade?

\section{CONECTOR}

Claro, será um prazer! Eu conheço um monte de gente do curso, do clube de música, da galera da academia, o pessoal do happy hour de sexta. Você pode me indicar algum material?

\section{EVANGELISTA}

Claro, leve isso. [Conector pega papel, deixa a plaqueta de "Conector" na estante de leitura e sai.]

\section{EVANGELISTA}

[Em segredo para a plateia] Ela é um Conector. Essas pessoas que fazem parte das redes informais são muito importantes! [coloca a plaquinha de Conector. A secretária pega a bata e coloca numa das cadeira e sai. Ao mesmo tempo fala] Aliás, quando estiver introduzindo uma nova ideia "Envolva Todos" [Cola a plaquinha Envolva Todos].

\section{EVANGELISTA}

Nesse ponto, já tem tanta gente conectada, que poderíamos criar um Grupo de Estudos sobre o assunto. [Cola a plaquinha Grupo de Estudos]

Só trabalho de trabalho 
Que trabalho me esbugalho

Quebro o galho me atrapalho

Mas não falho nem me canso

Tem reunião de reunião

Que reunião não abro mão

De discussão aprovação

E solução não tem descanso

Cena 7[Olha para o quadro, preocupado]

EVANGELISTA

[pensando alto] Estou preocupado com este Guru. [chamando] Cris! Preciso falar com você. [Cris entra]. Conversei com seu amigo Roberto sobre Desenvolvimento Ágil. Ele me fez um monte de perguntas, eu esclareci, mas ele ainda continua cético sobre o assunto. Seria interessante se você conversasse com o Roberto sobre as vantagens que você viu em usar Métodos Ágeis no projeto de CRM. Com certeza você tem História para Contar.

\section{Que ADOTA CEDo 1}

Claro, vou dar uma passada no escritório do Roberto e contar para ele sobre o projeto do CRM e como tivemos sucesso usando Desenvolvimento Ágil.

EVANGELISTA

Ótimo, Cris! [Cola a plaquinha História para Contar]

Cena 8

Que ADOTA CEDo 2

[Entra e pergunta para o Cris] Tenho ouvido ótimas coisas sobre o projeto do CRM. Quais são as quentinhas?

Que ADOTA CEDO 1

Acabamos de terminar a primeira iteração e o cliente está muito satisfeito.

Que ADOTA CEDO 2

[para Evangelista] Aposto que se você marcar um outro encontro, um monte de gente vai aparecer para ouvir sobre o sucesso deles!

\section{EVANGELISTA}

Taí uma boa ideia! Vou organizar para a próxima semana. Ah, olha aqui. [tira do bolso broche] Um dos caras do time mandou fazer esses broches. É sempre legal incluir Brinquedinhos que simbolizem a nossa ideia. 
QUE ADOTA CEDO 2

O que está escrito no broche? [Lê o broche] Eu sou Ágil. Muito legal!

EVANGELISTA

Aprovado? Então vou colocar aqui: "Brinquedinhos" [Cola a plaquinha Brinquedinhos] e vamos buscar os broches de vocês. [(Saem todos) ]

\section{Cena $9[$ O tempo passou $]$}

\section{EVANGELISTA}

[Entrando, para o público] Uau! Foi um evento sensacional! O pessoal que estava lá ficou tão eufórico com essa coisa de Ágil que eu decidi manter um encontro periódico. Criamos uma "Identidade para o Grupo" [Cola a plaquinha Identidade para o Grupo]. Se chamará Ágeis Anônimos!

QUE ADOTA CEDO 2

[Entrando, para Evangelista] Um dos programadores falou que consegue arrumar umas camisetas baratinhas. Não é ótimo?

\section{EVANGELISTA}

Parece divertido! Agora a novidade realmente boa! Recebi uma ligação da Linda Rising, que eu o encontrei na conferência. Ela vem para cidade a negócios e se ofereceu para falar com o nosso grupo! Ela é uma "Grande Personalidade" [Cola a plaquinha Grande Personalidade]

QUE ADOTA CEDO 2

Se for simpática, a gente convida para jantar.

\section{EVANGELISTA}

Não só ela é simpática, como também é cativante. Boa ideia, vamos chamar umas pessoas e convidá-la para um jantar particular, uma "Audiência Real" [Cola a plaquinha Audiência Real]. Podemos fazer a conferência no novo Centro de Convenções para tornar a coisa ainda mais especial e chamar a atenção para o evento.

\section{QUE ADOTA CEDO 2}

Eu estarei lá! Seria bom divulgar a palestra. Eu podia fazer uns cartazes e colar na sala do café.

\section{EVANGELISTA}

Ótimo! Deveríamos fazer mesmo mais propaganda dos encontros do nosso grupo e outros eventos. 
QUe ADOTA CEDO 2

Vou providenciar. [sai EA2]

Cena 10

EVANGELISTA

[deprê, pânico]Bom, agora estou de mãos amarradas. Não posso fazer mais nada enquanto meu gerente não chegar. Todo esse trabalho e nada dele aparecer [pausa]. Eu preciso do apoio de alguém grande e próximo de mim. Um Patrocinador Local. [Entra o Patrocinador Local]

PATROCinAdor LOCAL

[seco] Oi. Tudo bom?

EVANGELISTA

[Para o público] Depende... [para o Patrocinador Local] tudo bom...

PATROCinAdor LocAL

Eu tenho ouvido falar do trabalho que você está fazendo. [pausa]Bom!

EVANGELISTA

Obrigado senhor!

PATROCinAdor LOCAL

Nosso cliente comentou comigo que o projeto do CRM está sendo um sucesso porque vocês estão aplicando uma coisa chamada Desenvolvimento Ágil. De onde você tirou isso?

EVANGELISTA

Sabe aquela conferência que eu fui no final do ano passado? Eu conheci uns caras da comunidade Ágil muito bons e desde então venho me interessando pelo assunto.

PATROCinAdor LOCAL

Isso é bom. Seu trabalho não me passou desapercebido, eu venho acompanhando com interesse. Aliás, acho que já está na hora de envolver a diretoria nesse assunto todo. Prepare um relatório, dando uma visão geral, para a reunião de diretores da próxima 3a. feira. [Vai saindo]

EVANGELISTA

[acompanhando o Patrocinador Local até a porta] Pra Diretoria? Farei o meu melhor! Obrigado, chefe, pela confiança! [Voltando para sua mesa comemora] Diretoria! Diretoria! Diretoria! Agora já tenho um "PATROCINADOR LOCAL" e posso colocar a plaquinha [cola a plaquinha 
"Patrocinador Local")] [Sério] Acho melhor eu ter alguma coisa muito boa pronta até terça! [Trabalha furiosamente no computador]

\section{Cena 11}

Que ADOTA CEDO 2

Como é que foi a reunião com a diretoria ontem?

\section{EVANGELISTA}

Bem... eu acho [cara de decepção]. Só que os diretores querem falar com seus próprios Gurus para eles avaliarem as ideias Ágeis. Vamos ter que fazer alguns almoços com esses Gurus para que eu possa apresentar os tópicos e depois eles vão dar o parecer para os diretores.

Que ADOTA CEDo 2

Eu acho que nessa altura, a empresa já está preparada para isso! É só ter os argumentos certos para convencer os grandões. Eu gostaria de ir nesses almoços, se for possível. E outras pessoas também deveriam ir.

\section{EVANGELISTA}

Não pensei nisso. Deixa eu ver. É! Isso poderia me ajudar a alcançar um público maior e ganhar moral. Não sou um especialista em tudo. É verdade, preciso "Pedir Ajuda" [Cola a plaquinha Pedir Ajuda] [cantarolando Help enquanto QAC2 sai]! [EA2 sai, passa o tempo, cantalorando Help!]

$$
\text { Cena 12[Tempo] }
$$

\section{EVANGELISTA}

[Volta a trabalhar. Fica desanimado]Gente, como é difícil! Não estou aguentando. [olha o trabalho, suspiro] Aqueles gurus do almoço são muito críticos. Parece que eles não querem ouvir nada novo. Preciso de um "Ombro para Chorar" [Cola a plaquinha Ombro para Chorar]. [vinheta]O meu mundo caiu...

Que ADOTA CEDO 2

Até agora tudo foi muito fácil para você. Uma boa dose de realidade é bom, para você parar de pensar que tem poderes mágicos! Mas sério, ouça esses caras. Se você entender bem o que eles estão tentando te dizer, isso vai te ajudar a progredir de verdade. Não pense só na coisa que você está tentando vender. Leve os comentários como uma informação importante. Use a informação deles para saber exatamente como Métodos Ágeis se encaixam na NOSSA empresa. Use os céticos a seu favor: esse é o padrão "Sem Medo" [Cola a plaquinha Sem Medo].

\section{EVANGELISTA}

Eu sei o que você está falando, mas é fácil falar, e muito difícil de fazer na prática. 
QUe ADOTA CEDO 2

E a [Linda Rising]? Ela não pode ajudar?

\section{EVANGELISTA}

Nossa! Muito boa ideia! Há uma lista de discussão Ágil que eu podia assinar. Aposto que tem um monte de gente lá que pode me ajudar a superar isso. Vou fazer Terapia online! A União faz a força. [está animado de novo. QAC2 sai]

\section{Cena 13}

Que ADOTA CEDO 2

Você parece contente! Pelo jeito, as reuniões de acompanhamento estão indo bem?

EVANGELISTA

Incrível! O resultado foi tão bom que vamos tentar em mais alguns projetos. Teremos treinamento e consultoria no assunto. Mas a melhor notícia é que meu chefe vai deixar eu trabalhar 4 horas por semana só nisso! O diretor quer um relatório em poucos meses, mas acho que ele acredita na ideia! Não sou mais um Evangelista. Agora defender minha ideia faz parte do meu trabalho. Sou um "Defensor Dedicado" [Cola a plaquinha Defensor Dedicado].

QUE ADOTA CEDO 2

Quer saber, você merece! Você trabalhou duro nos últimos meses - já faz quase um ano hoje!

\section{DEFENSOR DEDICADO}

Isso. Semana que vem vai acontecer aquela conferência Ágil e eu estarei lá relatando a nossa experiência com desenvolvimento guiado por testes. Aliás, eu usei o padrão "Faça Arte" [Cola a plaquinha Faça Arte] e fiz uma musiquinha para ajudar a convencer as pessoas a usarem testes automatizados. Quer ouvir? [Canta a paródia do Teste Automatizado]

\section{Cena 14}

QUE ADOTA CEDO 2

Como é que foi a conversa com aqueles Gurus céticos?

\section{DEFENSOR DEDICADO}

Olha, por um lado você estava certo. Eu procurei ouvi-los e às vezes ouvir já basta. Eu tentei ao máximo manter minha mente aberta e aprender com o que eles estavam me dizendo. Acho que todos os planos dos projetos melhoraram só de ouvir o que os caras experientes tinham a dizer.

$$
\text { QUE ADOTA CEDO } 2
$$

Ótimo! É qual é o problema então? 


\section{DefEnsor DEDICADO}

Sabe, tem pessoas que simplesmente gostam de cutucar. Mas eu pensei, deixa rolar, que esse é o papel deles mesmo.

Que ADOTA CEDO 2

O papel do cético é cutucar.

\section{DefEnsor DeDicado}

Exatamente! Eu pedi para eles apontarem tudo que estivesse errado só no final da reunião. São os Defensores Céticos oficiais [Cola a plaquinha Defensores Céticos]. Eles ficaram quietos enquanto eu falava e dava até para ouvir os neurônios se fritando. Eles só querem ter certeza de que apontaram todos os riscos ou possíveis problemas. E quer saber? Ajudou muito! A gente precisa de pessoas assim!

QUE ADOTA CEDO 2

Então vocês viveram felizes para todo o sempre?

\section{DEFENSOR DEDICADo}

Claro que não. Semana passada um dos diretores me parou na sala do café com um monte de observações. Eu disse que ficaria feliz em fazer uma reunião com ele e esclarecer todas as dúvidas. Ele não sorriu, nem resistiu, mas ficou em cima do muro. Ele sugeriu, vê só, de nos encontrarmos às 19 horas de sexta-feira. E eu fui! Conversamos uns 20 minutos. Sabe o que eu descobri? Ele é como aqueles que têm medo da mudança, mas não querem fazer perguntas na frente de todos. Em particular tudo bem. Então eu fui lá sussurrar no ouvido do general. Isso é um padrão [Cola a plaquinha Sussurre no Ouvido do General].

\section{QUE ADOTA CEDO 2}

Tática digna de Napoleão. Você está acumulando experiência com tudo isso! Deveria escrever para dividir esse conhecimento com outros que estão tentando fazer a mesma coisa!

\section{Defensor Dedicado}

Engraçado você ter dito isso. Eu estava pensando em uma proposta de artigo: "Como introduzir Métodos Ágeis".

$$
\text { Que ADOTA CEDO } 2
$$

Eu acho que o que você aprendeu é mais do que como introduzir Métodos Ágeis! Isso o que você fez serve para introduzir qualquer coisa numa organização.

\section{DEFEnSOR DEDicAdo}

É verdade! São Padrões para introduzir novas ideias. [os dois olham para o quadro] 
Que adota Cedo 2

Parabéns! [com muito entusiasmo, me dá a mão e sai]

Defensor Dedicado

Obrigado!

${ }^{*} \mathrm{FIM} *$ 


\subsubsection{O Teatro e Padrões para Introduzir Novas Ideias}

Temos um roteiro que podemos usar para ensinar às pessoas sobre Padrões para Introduzir Novas Ideias. Para as pessoas que participarem da encenação da peça, alguns conceitos dessa dissertação ficarão muito mais claros. Elas interpretarão personagens que vivem os padrões.

Esse tipo de técnica (usar um roteiro teatral como forma de aprendizado) pode ser usado para ensinar qualquer tema. Esse tema pode ser justamente uma ideia que você está querendo introduzir. O teatro pode ser usado como uma mídia para comunicar uma nova ideia. Você pode escrever um roteiro sobre a sua ideia, ou pedir a ajuda das pessoas para escrever um roteiro junto com você. Pode-se, então, promover um encontro, onde as pessoas que você quer convencer vão encenar (ou assistir) a sua peça. Será uma experiência inesquecível para elas e você terá boas chances de ter sua ideia aceita.

\subsection{Música}

Se fôssemos analisar profundamente todas as relações que existem entre a música e a Computação (e a matemática), teríamos que dedicar um único trabalho da extensão deste para fazê-lo. Nos limitaremos apenas em ressaltar alguns pontos que consideramos importantes para o tema dessa dissertação.

Pudemos verificar, nas pesquisas que fizemos, tanto com alunos da disciplina de leitura dramática (Seção 4.1.4) quanto com profissionais da área da Computação (Seção 4.6 .1 e 4.6.2), que a música é a modalidade artística de maior interesse dentre pessoas que desenvolvem software. Sempre existe algum grau de rejeição por alguns tipos de Arte (como o teatro ou a dança), mas música é quase que unanimemente apreciada. Por esta razão, podemos usar a música para comunicar uma ideia. Ela pode ser uma excelente mídia de comunicação. Conforme mencionamos no padrão Faça Arte ${ }^{6}$, podemos compor uma canção que contenha, em sua letra, alguns elementos que representem a nossa nova ideia. Pode ser feita uma apresentação da música, em rodas informais de violão, ou numa reunião com comida ${ }^{7}$.

Gostos musicais semelhantes unem grupos de pessoas. Quando cantamos (ou tocamos instrumentos musicais), entramos em contato com o lado lúdico e criativo do ser humano. O ambiente com música se torna mais informal. Podemos aproveitar essa informalidade para introduzirmos uma nova ideia.

\footnotetext{
${ }^{6}$ Vide Seção 3.4.

${ }^{7}$ Vide Seção 2.4.3.
} 


\section{Música e Trabalho}

Na mesma época em que realizava este trabalho, tivemos a ideia de formar uma banda de rock dentro da empresa. Procurei saber quais eram as pessoas que já sabiam tocar alguns instrumentos ou que tinham tido experiências anteriores em bandas. Minha surpresa foi que já havia algumas pessoas se reunindo e ensaiando. Eram seis integrantes e eu me candidatei a entrar como vocalista. Apesar de já haver um vocalista na banda, sua voz alcançava notas mais agudas, enquanto eu fazia as músicas em tons mais graves. A combinação deu muito certo.

A banda tinha cinco pessoas da área de tecnologia, uma da área de web design e uma da área de operações, ou seja, quase todos os membros eram da área de exatas, a maioria formada em Engenharia ou Computação. Além disso, os componentes pertenciam a equipes diversas da empresa, o que contribuiu para uma aproximação entre essas equipes.

Depois que a banda estava ensaiada e com um repertório razoavelmente extenso, propusemos à diretoria fazer uma apresentação na festa de final de ano da empresa. A proposta foi muito bem aceita. Essa foi claramente uma conquista. Era a oportunidade de mostrar que Arte e trabalho podem andar em paralelo e que um pode apoiar o outro.

A música une as pessoas. A música desenvolve concentração, capacidade de trabalho. Ela exige dedicação. Ao formar uma banda, aprende-se a trabalhar em equipe: várias peças fundamentais e individuais em prol de um conjunto harmônico e com um objetivo em comum. Como forma de expressão artística, a música humaniza.

\subsection{Desenho e Pintura}

Todos que trabalham diariamente com desenvolvimento de software já falaram (ou ouviram falar muitas vezes) da palavra design. Todo desenhista ou pintor, assim como todo programador, para exercer sua profissão, precisa ter boas noções de design. Vamos entender então o que significa design, para depois entender qual a relação entre desenho, pintura e a programação. Uma possível tradução para o português da palavra design seria projeto. Entendendo mais profundamente o significado desta palavra, Richard P. Gabriel, em [Gab06] traz mais algumas definições interessantes: 
- Um plano mental. Um plano ou um esquema concebido na mente com intenção de uma futura execução.

- Um projeto é um plano sobre como construir alguma coisa. Projetar é construir algo na mente, mas não no mundo real - ou, melhor ainda, planejar como a coisa real pode ser construída.

- Projeto é o pensamento que alguém faz antes de construir.

- Projetos são as instruções baseadas em conhecimento que transformam recursos em coisa que as pessoas podem usar e dar valor.

Todas essas definições descrevem bem uma parte importante do trabalho de um programador. Todo os dias, ao se deparar com um problema para ser resolvido, o programador planeja mentalmente uma possível solução para seu problema. Após esse planejamento, o programador transcreve esse "plano mental" para um algoritmo, escrito em alguma linguagem de programação de sua preferência (ou talvez imposta pelo contexto).

Podemos definir aqui um processo: (1) surgimento do novo problema, (2) projeto mental para resolver, (3) execução da solução. Perguntamos então: esta solução criada pelo programador é a melhor solução para o problema? Essa solução é definitiva, ou pode se deteriorar ao longo do tempo? Podemos identificar facilmente um enorme ponto de limitação nesse processo. O limite está na capacidade mental de um ser humano de raciocinar logicamente sobre o problema e propor logicamente uma solução para ele. E se, mais para frente, esse mesmo programador perceber que alguém já tinha passado por esse mesmo problema e que a solução desta outra pessoa era melhor que a dele? Todo o tempo que o programador perdeu tentando resolver o seu problema teria sido inútil.

Com a popularização dos Métodos Ágeis no desenvolvimento de software, algumas deficiências deste processo (problema-projeto mental-execução) começaram a ser resolvidas. A metodologia XP introduziu a programação feita em pares. Aos pares, programadores discutem possíveis soluções. O plano não é mais limitado a uma só pessoa. Essa troca de experiências é extremamente benéfica para a criação de soluções mais robustas. Ainda assim, a solução está limitada ao plano mental de um grupo (equipe de desenvolvimento). Para essa limitação, XP trouxe outro poderoso conceito prático: design incremental [BA04]. A grande mudança é que não existe mais um enorme plano mental para se resolver um enorme problema inicial. Existem vários pequenos planos para vários pequenos problemas. São os chamados passos de bebê. Ao invés de criarmos mentalmente uma solução ideal enorme (que está além de todas as nossas capacidades mentais), vamos melhorando diariamente nossa solução atual. Como um pintor do Século XX que, dia-a-dia, vai dando novas pinceladas 
em seu quadro, aperfeiçoando um detalhe aqui, outro ali. O pintor não teve que necessariamente pensar na imagem que iria desenhar antes de começar sua obra.

Programar e pintar tem muitas características em comum [Gra04]. Em primeiro lugar, tanto pintores quanto hackers são criadores. Assim como compositores, arquitetos, escritores, o que pintores e hackers tentam fazer é criar coisas boas. Hackers querem programar, criar software útil e bem feito. Muitas vezes essa gana de criação é barrada pela academia, uma vez que para se destacar o que se exige são artigos e publicações. Nem sempre um bom software pode gerar um bom assunto para um artigo. Além disso, o assunto nem sempre é original. Um aluno de graduação em artes não precisa escrever um artigo sobre o quadro que ele acabou de pintar. A obra fala por si só. Por que um aluno de Ciência da Computação não pode ser avaliado pela quantidade e qualidade do software que ele desenvolveu? Talvez pela mesma razão que as aptidões escolares de uma aluno são medidas por testes de múltipla escolha padronizados, ou a produtividade de programadores pelo número de linhas de código. São testes simples de aplicar.

Como medir então o trabalho de um hacker? Funciona de forma parecida ao tentar-se avaliar uma pintura: é preciso ter um bom senso de design para poder julgar um bom design. E isso é difícil. Uma possível forma de avaliar é o fato de que coisas belas tendem a durar com o tempo, enquanto que as demais tendem a ser esquecidas. O problema é que, algumas vezes, esse tempo pode durar mais do que uma vida. Muitos grandes artistas só têm sua obra reconhecida após sua morte. É preciso que o tempo se encarregue de provar que a obra é boa.

Com relação à teoria, assim como pintores precisam entender a química das tintas, hackers precisam conhecer a teoria da Computação. A primeira versão da obra de um pintor é um esboço. O pintor olha o esboço e, a partir dele, começa a aperfeiçoá-lo. Assim fazem os hackers. Criam um pequeno código. Executam o código, vêem como ele se comporta. Fazem ajustes. As linguagens de programação são usadas hoje em dia para pensar nos programas, não para expressar programas que já foram pensados. A linguagem de programação seria um lápis, não uma caneta. 


\subsubsection{Beleza no código}

Programas são mais do que instruções para computadores. Eles podem ser tão belos quanto uma ponte estaiada bem projetada ou um quadro de Van Gogh [OW07]. Porém, para escrever um código belo e de qualidade, e para reconhecer a beleza em código, o programador precisa entender primeiro o que significa beleza. Ele também deve ler muitos programas escritos por mestres para que seja influenciado por código belo. Só então ele poderá usar o seu conhecimento técnico para projetar coisas belas. Antes de mais nada, é preciso ter bom gosto para fazer coisas boas.

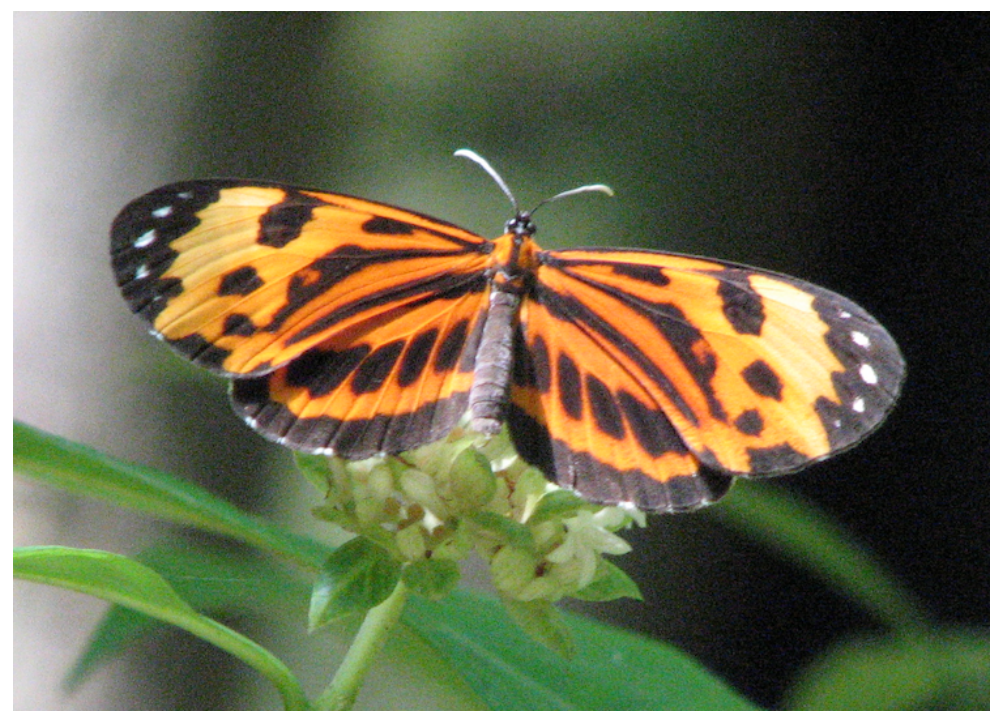

Figura 4.9: Anos e anos de aperfeiçoamento de projeto Paul Graham [Gra04] cita algumas características do que seria considerado belo em matéria de projeto (design) de software.

- Um bom projeto é simples - assim como na matemática a menor prova tende a ser melhor. Beleza em arquitetura de software significa poucos componentes muito bem escolhidos.

- Um bom projeto não depende de tempo - se o desenho não for perfeito, certamente aparecerá alguém que fará melhor. Buscar fazer hoje o melhor de todos os tempos é uma forma de garantir que o projeto é realmente bom.

- Um bom projeto resolve o problema certo - um exemplo contrário seria o de acendedores de fogão. Se as bocas estão em forma de quadrado, os acendedores deveriam ser dispostos na mesma forma, e não em linha.

- Um bom projeto é sugestivo - em software significa dizer que você deveria dar aos usuários alguns elementos básicos para que eles possam combiná-los como queiram, como Lego.

- Um bom projeto é ligeiramente divertido - não que o projeto precise ser engraçado, mas dificilmente ele não terá seu lado de humor se for realmente bom. 
- Um bom projeto é difícil - para subir uma montanha alta é preciso deixar grande parte das coisas em excesso pelo caminho. Animais selvagens são bonitos provavelmente porque eles levam uma vida difícil.

- Um bom projeto parece fácil - provavelmente porque muito trabalho foi empenhado nele, porém esse trabalho não é normalmente percebido por olhares externos. Um pianista treina horas por dia durante anos. Ele treina o inconsciente (seu corpo) para realizar tarefas que conscientemente não seriam possíveis. Ele consegue, então, tocar muito mais notas simultâneas do que seu cérebro teria a capacidade de enviar comandos para suas mãos.

- Um bom projeto usa simetria - como a própria natureza usa (Figura 4.3.1). Um exemplo em programação seria o uso de recursão. Recursão e simetria também estão presentes na torre Eiffel. Um projeto de software, como um projeto arquitetural, pode ser visto como algo essencialmente geométrico. Criar software é fundamentalmente criar e quebrar simetria [Zha08].

- Um bom projeto assemelha-se com a natureza - a natureza já teve milhares de anos para trabalhar e resolver um determinado problema. Provavelmente, a solução que ela encontrou é boa. Assim como barcos imitam peixes e aviões pássaros.

- Um bom projeto é um re-projeto - dificilmente algo dará certo de primeira. Quem é bom projeta de maneira que o produto seja flexível o suficiente para ser alterado no futuro. Um exemplo em software é o uso de refatorações (Figura 4.3.2).

- Um bom projeto acontece em várias partes ao mesmo tempo - para ser um Leonardo, você precisaria mais do que a habilidade que a ele foi nata. Você precisaria de Florença em 1450.

- Um bom projeto normalmente é ousado - os melhores trabalhos surgem quando alguém vê algo ruim e diz: "Eu posso fazer melhor do que isso". Se mantivermos o comportamento padrão, igual a todos, dificilmente faremos algo diferente do que está ruim hoje. Para criar algo novo é preciso ousadia.

\subsubsection{Refatoração em Desenho}

Uma técnica conhecida no desenvolvimento de software (e uma das práticas defendidas pela metodologia XP) é a Refatoração [Fow00]. Ela consiste em executar uma série de pequenos passos que visam a deixar o código mais claro, mais bonito, mais elegante. Normalmente, o resultado de uma refatoração é um projeto mais simples e de mais fácil manutenção. Muitas vezes, a refatoração leva à criação de abstrações e generalizações no código. 


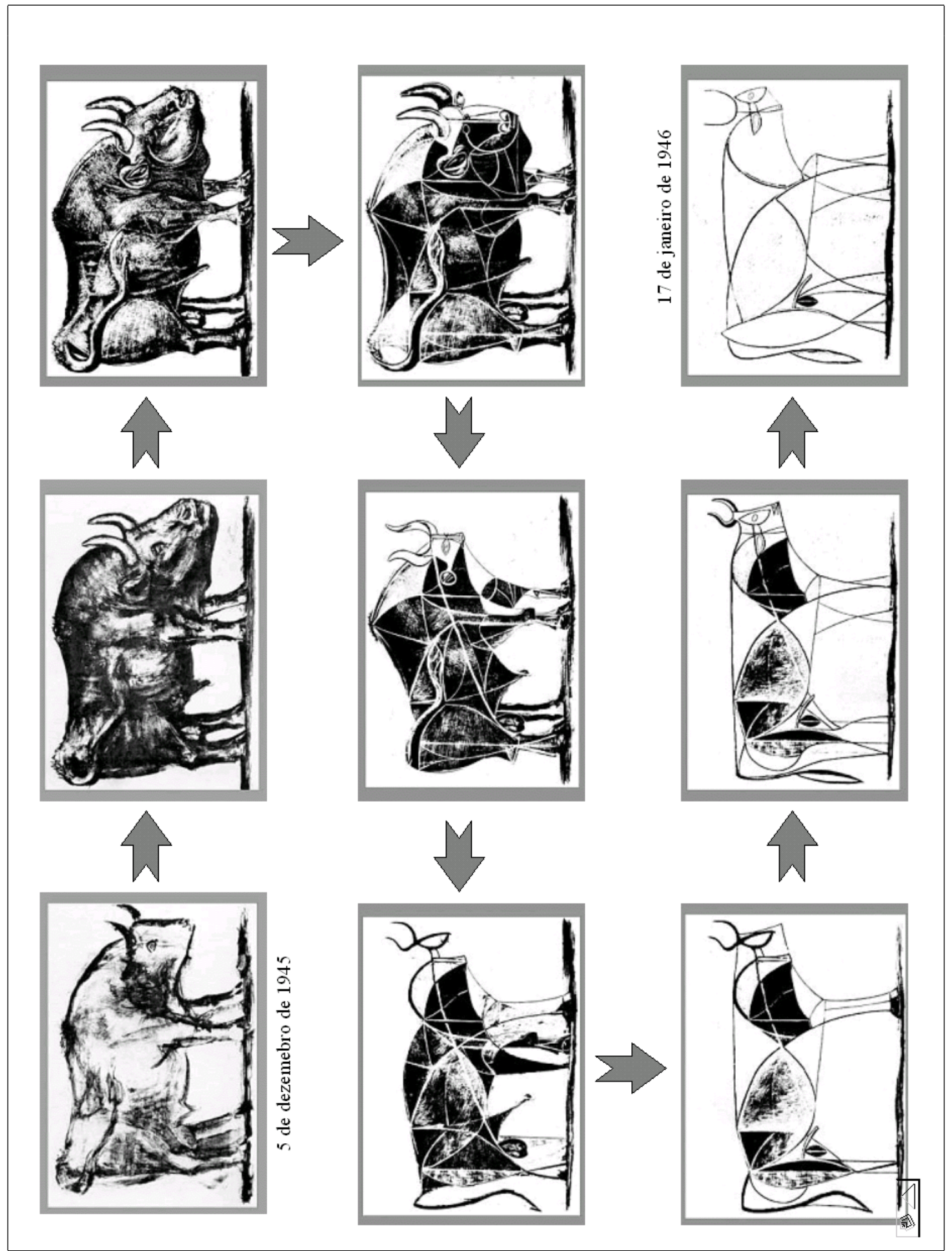

Figura 4.10: Refatoração em Desenho 
Um exemplo simples: vamos supor que estejamos programando a classe de dados Pessoa. Essa classe contém atributos como nome, peso, idade, idioma que fala. Num segundo momento eu percebo que preciso inserir gatos no meu sistema. Então crio a classe Gato com os atributos nome, peso, sexo e cor do pelo. Em seguida percebo que criei uma ambiguidade. Ambas as classes Gato e Pessoa possuem atributos em comum. Através de uma refatoração, crio a classe Animal com os atributos em comum (nome, peso, sexo) e faço com que as classes Gato e Pessoa "herdem" as propriedades de animais.

A ideia de extrair abstrações é a de identificar a essência do sistema e descrever com elementos simples suas características mais profundas. Para chegar nessa essência é preciso muita experiência e

suor. É preciso programar muito bem e saber usar, de forma maestral, a linguagem e as ferramentas à disposição. É uma Arte.

Observe como são feitas refatorações no desenho de Pablo Picasso [pic46] na Figura 4.10 onde inicialmente o pintor desenha um touro completo e normal. A cada novo estágio do desenho (são 11 gravuras no total), as partes irrelevantes vão sendo retiradas, porém a ideia central do touro permanece. O processo de desconstrução do gênio dura 6 semanas. Mesmo com pouquíssimos traços, o último desenho consegue representar claramente o touro. São os traços essenciais do animal.

Todo bom programador, criador de software, deve saber reconhecer os aspectos essenciais de um sistema. A técnica ajuda na execução, mas a genialidade está no pensamento intuitivo e na capacidade artística de identificar e extrair a essência.

\subsubsection{Desenho, Pintura e Padrões para Introduzir Novas Ideias}

Como vimos anteriormente, algumas habilidades desenvolvidas com o desenho e a pintura podem ser usadas em benefício do desenvolvimento de software. Essas habilidades também podem ser utilizadas para introduzir uma nova ideia. Como o desenho e a pintura nos ajudam a reconhecer a essência e abstrações, eles também nos ajudarão a identificar a essência da ideia que estamos querendo introduzir. Não só a pessoa que quer passar uma nova ideia precisa reconhecer a sua essência: quem está sendo convencido da ideia também precisa entendê-la para poder aceitá-la. Para entendê-la, é necessário que se entenda sua essência.

Se uma nova ideia de projeto de software é boa, provavelmente ela tem alguns dos atributos de beleza vistos na seção anterior: simetria, simplicidade, independência no tempo, humor, parecer fácil, assemelhar-se com a natureza, etc. O defensor do projeto precisa saber identificar esses atributos. Ele precisa reconhecer quais são as características de sua ideia que a tornam bela. De outro lado, a pessoa que está ouvindo a nova ideia de software precisa ter o senso estético necessário para reconhecer essa beleza. 
Saber reconhecer a essência de algo e ter a capacidade de identificar todos os atributos de beleza que citamos anteriormente são habilidades importantes quando se quer introduzir uma nova ideia. O desenho e a pintura são atividades artísticas que nos ajudam a desenvolver essas habilidades.

\subsection{Poesia}

"A poesia situa-se nas margens do entendimento, nas fraturas da nossa realidade, no espaço entre ordem e caos"

Richard P. Gabriel

Um programa de computador pode ser visto como a expressão de uma ideia (abstrata) em uma determinada linguagem de programação. Preparar um programa, pode ser como compor uma poesia ou uma música [Knu74]. A linguagem de programação só serve para que uma ideia do mundo real seja interpretada e processada por um computador. Se chegarmos ao lado de um computador hoje e pedirmos "computador, por favor, ordene uma lista de nomes em ordem alfabética", provavelmente o computador não fará nada. Mas talvez alguém poderia escrever um programa numa língua que o computador entende e pedir para ele (nessa língua) que ordene tal lista.

Vamos supor que um hacker sabe perfeitamente como funciona o algoritmo de ordenação quicksort. O algoritmo quicksort descreve passos bem definidos para se ordenar uma lista de elementos. O algoritmo pode ser resumido em três passos:

1. Escolha um elemento da lista, denominado pivô;

2. Re-arranje a lista de forma que todos os elementos anteriores ao pivô sejam menores que ele, e todos os elementos posteriores ao pivô sejam maiores ou iguais a ele. Ao fim do processo o pivô estará em sua posição final. Essa operação é denominada partição;

3. Refaça o processo para cada uma das sub-listas: a sub-lista com os elementos menores que o pivô e a sub-lista com os elementos maiores ou iguais.

Esses passos são ideias do mundo real (lista de nomes, dividir a lista, elementos maiores de um lado, menores do outro, etc.) e foram descritos acima na língua portuguesa. Se explicarmos (em português) os passos acima a um aluno do Ensino Médio e este aluno entender português, provavelmente ele saberá executar esses passos e ordenar uma lista de nomes usando o quicksort. Se colocarmos as palavras acima em um computador, ele não entenderá nada e não realizará a operação que desejamos. Para "falarmos" com o computador precisamos falar a língua dele.

Continuemos supondo que damos ao nosso aluno de 2o. grau a seguinte frase: 
sort []$=[]$

sort $(x: x s)=\operatorname{sort}(f i l t e r(<x) x s)++[x]++$ sort $($ filter $(>=x) x s)$

Provavelmente esse aluno não entenderia nada sobre as duas frases acima. E se mostrássemos a mesma frase ao hacker que conhece o algoritmo quicksort? Ainda assim esse hacker não saberia do que se trata o trecho acima, a não ser que o hacker conhecesse a linguagem de programação Haskell. Um computador entenderia o programa quicksort em Haskell se déssemos a ele um "interpretador", ou seja, se "explicássemos" para o computador como a linguagem Haskell funciona. Se conseguíssemos explicar para o aluno do 2o. grau como funciona a linguagem Haskell, ele entenderia o código acima também. Estamos falando de aprendizado de uma linguagem. Estamos falando sobre como expressar ideias usando uma linguagem. Como se aprende uma língua? Falando? Escutando? Escrevendo? Lendo? Tudo isso junto?

\section{Do que é que se trata [Cuk09]}

Só trabalho de trabalho

Que trabalho me esbugalho

Quebro o galho me atrapalho

Mas não falho nem me canso

Tem reunião de reunião

Que reunião não abro mão

De discussão aprovação

E solução não tem descanso

Não sei dormir só produzir

Mais investir me instruir

E progredir pra onde ir

Não vou medir nenhum esforço

Para parar paralisar

De trabalhar vou disparar

Do chão pro ar me preparar

Prá programar roendo o osso

Sou animal que toca o pau

E não faz mal não ter sinal

No meu ramal de alguém normal

Isso é legal e não é pouco 
Trabalho assim não é pra mim

É que compus sombra sem luz

Você já viu é como um rio

Um não sem til correndo louco

Mesmo que dominemos uma língua, é possível a nós expressar todas as nossas ideias nessa língua? É sabido que existem palavras que só existem em determinadas línguas e que não podem ser traduzidas. Toda língua é limitada às suas regras gramaticais, ortográficas. Não só limitada a essas regras, mas ao seu vocabulário. Quando pensamos em poesia com métrica e rima, limitamos ainda mais nossas possibilidades de expressão. Brigamos diariamente com nossa língua natal para conseguirmos expor nossas ideias. É uma luta constante. Da mesma maneira, um programador briga o tempo todo com a linguagem de programação que ele conhece, limitada. Ele precisa fazer o computador entender mensagens, comandos. A linguagem é composta de poucos símbolos e esses símbolos precisam ser arranjados de forma perfeita para representar algo. É uma tarefa quase mágica, exige muita criatividade por parte do programador.

Todo problema em Computação pode ser resolvido de infinitas maneiras diferentes. Hackers [AFdA09] são pessoas extremamente criativas. São criadores. São inventores. A Ciência de software vem sendo estudada há poucas décadas. Grande parte de todo software que se faz é novo. Software interessante de se fazer é justamente o que não foi feito ainda. Os hackers querem isso: fazer sempre bons e novos sistemas. Sendo um criador, o programador deveria ser treinado da mesma forma que uma pessoa criativa. Um programador deveria ser treinado como um artista ou um poeta [Hei02]. Como poetas são treinados? Eles estudam obras de grandes poetas: Fernando Pessoa [Pes05], Hilda Hilzt, Federico Garcia Lorca, Carlos Drummont de Andrade, Lord Byron, Vinícius de Moraes, Pablo Neruda, Manuel Bandeira. Isso é feito com software? Por acaso nossos alunos estudam a vida e a obra de grandes programadores [Bur08]? Será que eles conhecem bem nomes como Alan Kay (Smalltalk), Ralph Johnson (Padrões), Donald Knuth (Análise de Algoritmos), Mark Spencer (Asterisk), Linus Torvalds (Linux), Yukihiro Matsumoto (Ruby), John McCarthy (LISP), James Gosling e Guy Steele (Java), Martin Fowler (Refatorações), Dave Thomas? Nossos alunos de Computação não olham bons códigos, de programas importantes. Não olham a arquitetura ou o projetos de bons sistemas, bibliotecas, arcabouços. Em suma, eles não estudam a fundo aquilo que eles estão tentando construir.

Um bom poeta só aprimora sua qualidade na escrita depois de escrever muito. Assim acontece com um bom programador. Ele deve escrever muito código para ficar bom. O grande poeta, antes de se tornar grande, teve contato com grandes poesias de outros poetas. Ele teve que mostrar suas poesias a críticos. Sua poesia foi avaliada e revisada. Um escritor fica bom somente após várias iterações deste processo: leitura, escrita, revisão. Para ficarmos bons em escrever software, temos 
que praticar, temos que ler muito e temos que estar num contexto onde nosso código (nossa escrita) pode ser avaliado e revisado.

Nas metodologias ágeis, o processo de criação de software se tornou interativo:

1. Cria-se uma parte do software

\section{O cliente revisa}

3. O software é melhorado

4. O cliente revisa novamente

As Metodologias Ágeis trabalham com a premissa de que não podemos planejar todo o software antecipadamente. Se pudéssemos, não haveria a necessidade de lançarmos várias versões.

Pode parecer estranho, mas escrever software e escrever poesia exige o mesmo tipo de concentração. É pensar em possibilidades, pensar em como fazer da melhor forma, pensar em como ser elegante, como simplificar, como usar a língua de forma eficiente. Se olharmos para o código fonte de programadores extremamente talentosos, certamente encontraremos beleza lá.

Uma maneira de exercitar a escrita é trabalhar em algum projeto distribuído, por exemplo, num projeto de Software Livre, onde um grupo de desenvolvedores espalhados pelo mundo trabalham na criação de um software. Nesse tipo de projeto, o programador é obrigado a se comunicar por escrito (emails, fóruns, listas

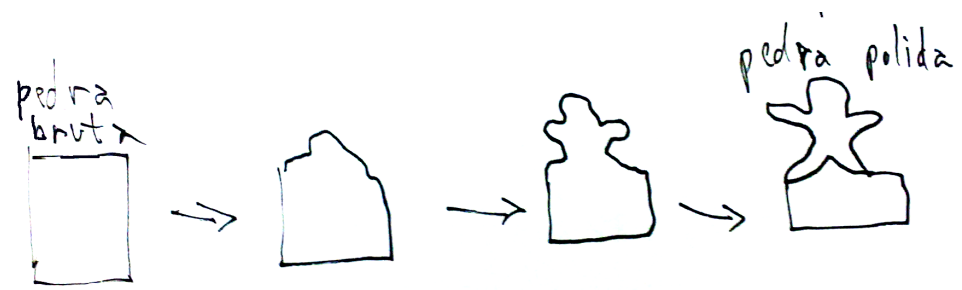
de discussão). Ele precisa escrever documentos e disponibilizar informações para os outros. Esse trabalho ajuda a desenvolver as habilidades na comunicação escrita. E escrever é uma forma de trazer mais disciplina para o processo de desenvolvimento de software [GG05].

Escrever software também exige uma constante interação com as pessoas que usarão esse software. A comunicação com essas pessoas precisa ser da melhor qualidade possível. Temos que saber entender as vontades e desejos dessas pessoas. Em Métodos Ágeis, usamos artefatos como "histórias" [Coh04], que são breves descrições de funcionalidades da sistemas desejadas pelo cliente. Entender com precisão o que cada história pede é fundamental para a criação de um software que atende às necessidades desse cliente. O domínio em disciplinas de comunicação, como poesia e teatro, ajuda a eliminar os mal entendidos que a língua oferece. Escrever software é uma Arte [Knu74] e leva muitos anos para alguém ficar bom. 
Um bom programador deveria se comunicar bem com pessoas, não só com computadores. Não somente para entender o que essas pessoas querem que ele crie, mas também para elas saberem das dificuldades, dos desafios, das limitações e situações que o programador enfrenta ao realizar seu trabalho. Alguns ainda pensam que programar é uma atividade secundária no desenvolvimento de software, quando na verdade é uma atividade central, difícil, humana e social.

Desenvolvimento de software é uma Arte [Knu74]. Como todas as artes, não pode ser ensinado e aprendido como uma Ciência precisa, com teoremas e fórmulas. Como um quadro (elaborado por um pintor) ou um prédio (idealizado por um arquiteto), um produto de software incluirá o toque pessoal de quem o desenvolveu [AM06].

Um dos pré-requisitos mais importantes hoje dia para se desenvolver sistemas complexos é a capacidade do time de estabelecer a mais alta qualidade na comunicação com o cliente interessado no sistema. Todo sistema é desenvolvido para resolver (ou ajudar a melhorar) um problema do mundo real, um problema que pertence a um domínio específico. Para que haja uma comunicação eficaz entre desenvolvedores e especialistas no domínio da aplicação, é importante que se estabeleça um Linguagem Ubíqua [Eva04]. Essa tarefa não é fácil. Definir uma linguagem comum e que defina com precisão o domínio da aplicação é um desafio da mesma forma como é um desafio poder se expressar de forma clara usando a língua falada. O exercício com a poesia permite que se desenvolva habilidades com as palavras e com a língua. Trabalhar poesia exige atenção com os verbos, substantivos, pronomes. Fazer isso aguça a relação que um indivíduo tem com a sua própria maneira de se expressar e também a sua capacidade de compreender as mensagens de outras pessoas.

Antes de ter a capacidade de modelar com qualidade um domínio de aplicação, a pessoa precisa desenvolver o seu conhecimento na língua em que esse modelo será definido e comunicado. Existem diferenças sutis entre palavras que parecem significar a mesma coisa. Essas pequenas sutilezas podem ser exatamente o que irá diferenciar um bom modelo de domínio de um modelo pobre e ambíguo. Por exemplo, se ao modelar um sistema eu decidir usar o termo "Usuário" no lugar de "Cliente", existe uma diferença importante entre o significado dessas duas palavras, que talvez para um mal conhecedor da língua pode passar desapercebida. Um termo sempre será melhor que outro dado um domínio específico, mas se o desenvolvedor não souber a distinção poderá usar o termo errado e comprometer seriamente o entendimento.

Pode-se usar a ideia de refatorações [Fow00] também para a escrita de textos e poesias. Escrever é um processo de aprendizado contínuo, na medida em que se escreve, se lê, se re-escreve, se re-lê [Gab02]. Pedaços de texto são retirados, substituídos por outros, sintetizados em outros. Pode-se dizer que uma obra escrita, assim como uma pintura, nunca está terminada. Apenas deixa-se de trabalhar nela no momento em que ela parece suficientemente boa. Inicialmente, a obra é uma pedra 
bruta, sem forma, que vai sendo aparada e recebendo identidade na medida em que o trabalho de escrita é refinado (Figura 4.11).

Trabalhar a capacidade de escrever poesias é o mesmo que trabalhar a capacidade de criação. Como hoje, software é criação (e Arte), a poesia ajuda a aperfeiçoar a habilidade de programar.

Um programador que decide treinar escrevendo poesias visa melhorar:

1. Sua habilidade de escrever.

2. Seu conhecimento na língua em que escreve.

3. Exploração de alternativas e do espaço de soluções.

4. Sua habilidade em se expressar numa língua.

5. Sua habilidade em programar, já que programar não deixa de ser uma maneira de expressar ideias usando uma linguagem definida.

\section{A descida [Cuk09]}

Hoje eu desci a via em dois ciclos

Um ciclo na frente e outro de carona

Ligados pela corrente que faz

O vôo dos meus pés

De ágil às ruas

Tão frágil nas palavras

Querendo ligar e relacionar

O lógico com o mole

O imoral com a vida

Flutuam nas rimas

Des-rimas sentidas

Olhando claramente quão longe de lá

Longe está, meu pensar e meu pesar

Sonhos, vertigens, suspiros

Controle de regras fatídicas

De golpes cruzados e vazios

Um sopro de lucidez

Luz e paralepsia

Conversas de um solto no cosmo 
Um louco de origem, desnudo, solfista

Filosofia de restos de palha

São crias, são frias e velhas

Fedidas e lindas poesias

No ouro de ouvidos atentos me guio

Me expresso, me roubam a única coisa que resta

Só festa se fazem, não presta

Estou preso, direto para o poço me jogam

Malditas cuspidas eu levo

Sou bicho, sou néctar divino

Descalço na via que desço

De ciclos e correntes que ligam

Tudo isso, o inferno do dia

Solteiro e legítimo broto de merda

Puríssimo como se apenas pronto

Feito só para servir.

\subsubsection{Poesia e Padrões para Introduzir Novas Ideias}

Quando alguém pratica escrita de poesias, essa pessoa desenvolve grandes habilidades com as palavras e os símbolos da língua (no caso de poesias em línguas orientais como o japonês ou chinês). Essa habilidade contribui para a eficiência em se expressar. Não podemos esquecer que programar também tem a ver com expressão de ideias através da manipulação de símbolos e palavras (comandos da linguagem). A habilidade em lidar com as palavras nos ajuda a programar melhor e a comunicar uma nova ideia. Ao desenvolver a capacidade de escrever poesias, você pode escrever uma cujo tema seja a ideia que está querendo implantar. Essa poesia pode servir de letra para uma música ${ }^{8}$.

Mesmo que uma ideia seja muito boa, se não for comunicada de forma eficiente, dificilmente ela será aceita. Mesmo que uma linguagem de programação seja ótima (como o Ruby), pouco adianta se o programador não souber usar os comandos e conceitos com maestria.

\footnotetext{
${ }^{8}$ Vide Seção 4.2 .
} 


\subsection{Meditação}

Existem centenas de técnicas e formas diferentes de meditação. Nosso objetivo não é explicar cada uma das técnicas, apenas mostrar alguns poucos exemplos de como a prática meditativa, de forma geral, pode beneficiar o desenvolvimento de software. Andy Hunt [Hun08] afirma que

"Programação tem pouco a ver com escrever software usando uma linguagem críptica (embora, temos um curioso apego a esse hábito). A programação é toda sobre resolução de problemas. Exige criatividade, engenhosidade e invenção."

Andy também apresenta em seu livro os benefícios da meditação, que vem sendo adotada em muitas empresas, não só por questões de bem-estar e saúde, mas como técnica para o aperfeiçoamento da capacidade de cognição de um indivíduo. Um estudo publicado na Biblioteca Pública de Ciência Biológica [Jon07] mostra que a meditação também pode aumentar a capacidade de um indivíduo de prestar atenção durante o dia. O nosso intuito é apresentar a meditação como uma ferramenta de expansão da criatividade, da consciência e do bem estar. Muitas das práticas de meditação conhecidas hoje tiveram origem na Índia. Coincidência ou não, esse país é considerado um dos maiores fornecedores de mão de obra para a indústria de software.

Em Innovation Happens Elsewhere [GG05], Richard P. Gabriel fala sobre a criatividade:

"Criatividade é encarada por muitos como um talento que algumas pessoas são abençoadas por ter. Talento, porém, é o que vem fácil. Para artistas, cientistas, engenheiros e escritores, criatividade vem da habilidade de juntar vários gatilhos que estão acontecendo; um gatilho é qualquer coisa que faz surgir um pensamento na mente."

Esses gatilhos estão presentes em toda história da humanidade, como aquele da maçã que caiu na cabeça de Isaac Newton. Na solução de problemas, gatilhos podem vir de vários lugares. Muitos cientistas e matemáticos relatam que a solução de seus problemas apareceram quando eles estavam realizando atividades não relacionadas ao problema. A meditação pode ser justamente uma dessas atividades. Ao entrar em estado meditativo, uma pessoa tem a oportunidade de entrar em contato com alguma realidade mais profunda, conectando-se a verdades que até então tinham passadas desapercebidas pelos sentidos e inter-relacionando gatilhos que levam essa pessoa a conclusões criativas [Lyn08].

Uma primeira evidência científica que podemos citar é a de que a meditação melhora a concentração mental.

A diferença entre meditadores experientes e novatos mostra que a capacidade de atenção pode ser afetada através de treinamento da mente [LDTD07]. 
Estudos recentes, com imagens de ressonância magnética do cérebro de praticantes de meditação, mostram que a capacidade de concentração pode aumentar com treinamento de meditação [LGR $\left.{ }^{+} 04\right]$. Como a concentração é um elemento chave na atividade de programar, meditar ajuda diretamente a programar. Para entender mais de perto como isso se processa, vamos explicar de forma breve o funcionamento da prática de meditação Vipassana.

\subsubsection{Vipassana}

"O primeiro pilar da meditação é a concentração-estabilidade da mente. Nós focamos nossas energias que normalmente estão espalhadas. Cultivamos um estado tranquilo, relaxado, aberto, produtivo, gentil e suave. Deixamos as coisas serem. Não ficamos na expectativa de experiências. Nossa mente fica em alerta e profundamente conectada com o que está acontecendo" [Sob07]

Vipassana significa "ver as coisas como elas realmente são". É uma prática de meditação que existe há mais de 2500 anos. Ela foi trazida da Índia para o ocidente pelo professor Satya Narayan Goenka. Hoje existem dezenas de centros de Vipassana, que ensinam a prática em cursos de 10 dias. Os cursos não são cobrados. Todas as despesas são bancadas por doações de ex-alunos. A técnica também já foi ensinada com grande êxito em prisões da Índia, Israel, Mongólia, Nova Zelândia, Tailândia, Inglaterra e Estados Unidos [CVPA95]. A meditação não está ligada a nenhuma seita ou qualquer tipo de ritual religioso. Sua abordagem é livre de dogmas, crenças ou sectarismo [Har87].

O objetivo principal da Vipassana é a eliminação das "impurezas" da mente, causa primária do sofrimento humano, segundo os ensinamentos dessa técnica, de origem budista [SL90]. Segundo a teoria dessa técnica de meditação, o sofrimento existe por causa de duas razões básicas: apego e aversão. O apego é tudo aquilo que desejamos e que não temos, ou que temos chances de perder (dinheiro, entes queridos, prazer, etc.). A aversão é tudo aquilo que temos, porém não desejamos ter (dor, doenças, etc.). Uma solução temporária muito usada para eliminar o sofrimento é a de distrair a mente, ocupando-a com entretenimentos (cinema, esportes, teatro, jogos, etc.). Com essas distrações o sofrimento não é eliminado. Ele apenas é enviado para uma região mais profunda da mente. Segundo a Vipassana, somente a observação direta do sofrimento pode ajudar na sua eliminação [SL90].

A técnica ensina de forma prática como observar as impurezas da mente. Quando uma impureza (apego, aversão) surge, processos corporais são desencadeados. A respiração altera ligeiramente sua frequência e sensações sutis podem ser observadas pelo corpo. É um fenômeno físico mental: pensamentos e emoções se manifestam fisicamente na respiração e nas sensações. Essas sensações devem ser observadas sem julgamento. Não se deve repelir a dor ou se deslumbrar por sensações agradáveis e maravilhosas. Dessa forma se "treina" a mente a não reagir com apego e aversão às coisas. 

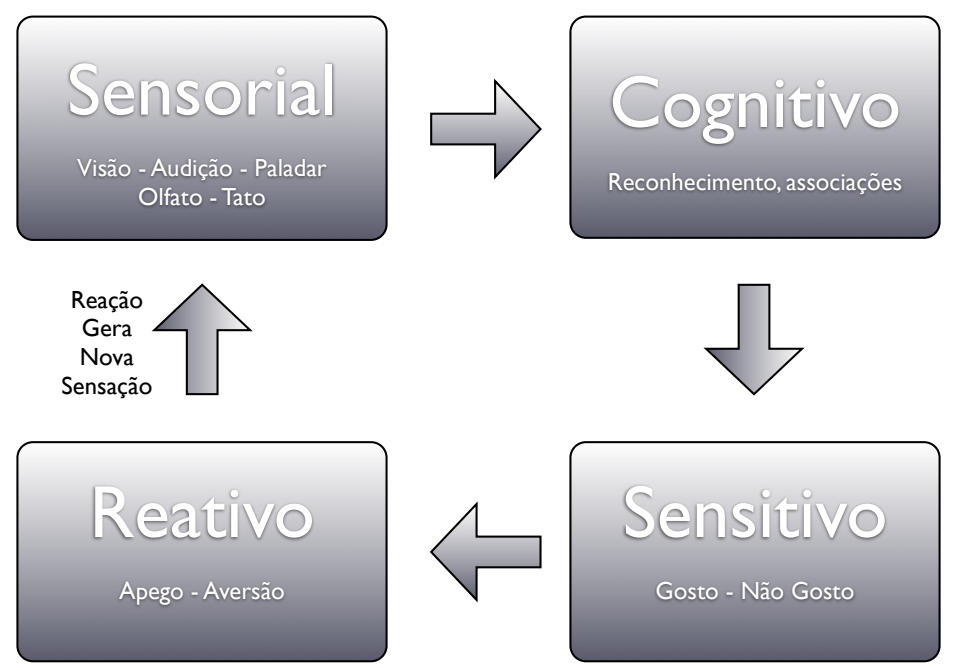

Figura 4.12: Vipassana: Modelo Mental Simplificado

Os processos mentais ocorrem segundo o modelo simplificado da Figura 4.12. A partir de um estímulo sensorial surge uma cognição. Da cognição automaticamente atribuímos um gosto ou um desgosto. Após esse "julgamento" de gosto, surge um sensação no corpo, que pode ser agradável ou desagradável. Dessa sensação vem a reação. A Vipassana trabalha para interromper o fluxo mental na sensação, eliminando a reação, que segundo a técnica é a principal geradora de mais sofrimento.

Os cursos básicos de Vipassana são dados em retiros de 10 dias. Os participantes (no Brasil, normalmente grupos de 60 pessoas) são orientados a permanecer em silêncio durante todo esse período. Além disso, eles devem seguir regras de conduta como não roubar, não ingerir substâncias tóxicas e não ter relações sexuais. O objetivo de toda essa rigidez é apenas ajudar os alunos a focarem os 10 dias de permanência no aprendizado da técnica. Não tendo outras preocupações ou atividades, a meditação pode ser aprendida com mais facilidade.

Existem vários estudos feitos pelo Vipassana Research Institute (http://www.vridhamma.org/) que comprovam a eficácia nos seguintes quesitos:

- Diminuição de ansiedade e depressão

- Melhoria na esperança e bem estar 
- Redução de hostilidade

- Menos medos

- Mais desejo por amor, família, educação e trabalho

Quem participa de um curso como esses percebe os benefícios imediatamente após o término dos 10 dias.

\subsubsection{Meditação Transcedental}

Outra meditação que se tornou muito famosa no Ocidente foi a Meditação Transcedental. Ela foi trazida pelo Mestre Maharishi Mahesh Yogi e popularizou-se muito devido ao envolvimento dos Beatles com a prática. O Mestre Maharishi dizia que "Seguindo os ensinamentos da Meditação os homens e mulheres serão mais eficazes em todos os níveis da vida, o que lhes trará satisfação. E as necessidades de nosso tempo serão também preenchidas". A Meditação Transcedental é ensinada num ciclo de instruções que dura 6 dias, onde o aluno recebe as informações de como meditar em dois turnos de 20 minutos por dia, todos os dias.

David Lynch, um dos maiores cineastas da atualidade escreveu um livro [Lyn08] contando os efeitos benéficos dessa meditação. Ele conta que pratica a meditação há mais de 30 anos. Usamos esse exemplo de literatura para mostrar que a meditação pode ter um efeito ainda mais benéfico com pessoas que desempenham trabalho criativo e atividades artísticas. Consideramos criar software uma Arte e por isso a meditação tem muito a agregar a essa Arte.

Foram feitos vários estudos sobre a eficácia da Meditação Transcedental na melhoria da qualidade de vida das pessoas, de onde surgiu o conceito conhecido como Efeito de Maharishi [BL76]. Em 1960, Maharishi afirmou que se 1\% da população mundial praticasse a técnica, a qualidade de vida de toda a população aumentaria drasticamente. Esses estudos mostram que quanto maior o número de pessoas que praticam a meditação, menor é a criminalidade e a violência na cidade onde se pratica.

\subsubsection{Meditação e Padrões para Introduzir Novas Ideias}

Muitas vezes, quando temos uma ideia muito diferente e queremos convencer as pessoas, precisamos ir Passo a Passo ${ }^{9}$, fazer O Suficiente ${ }^{10}$ e agir na Hora Certa ${ }^{11}$. Quando estamos muito ansiosos, nem sempre é fácil aplicar esses padrões. A prática de meditação pode ser um grande aliado. Ela

\footnotetext{
${ }^{9}$ Vide Seção 2.2.5.

${ }^{10}$ Vide Seção 2.9.3.

${ }^{11}$ Vide Seção 2.4.4.
} 
ajudará a controlar a ansiedade. Assim, teremos paciência e tranquilidade para agir na medida certa, pouco a pouco e nos momentos mais adequados.

A meditação também nos ajudará a entender com clareza nossa própria ideia e como as pessoas são afetadas por ela. Ela permite mergulhar fundo num pensamento e conhecer tanto a natureza da ideia quanto as suas consequências mais sutis. A prática contínua de meditação permite uma maior compreensão da natureza humana. Nos tornamos mais sensíveis aos comportamentos e sentimentos dos outros. Para introduzir uma ideia, precisamos saber como lidar com as pessoas. Para lidar com elas, precisamos entendê-las. Meditar nos ajuda a entendê-las, assim como entender a nós mesmos, nossas ideias e como elas afetam os outros.

\subsubsection{Meditação, XP e Mudanças sem Medo}

Em maio de 2008, tive o privilégio de mais uma vez participar de um mini-retiro de Vipassana. Um curso inteiro de Vipassana dura 10 dias. Alunos que já fizeram o curso se reúnem uma vez por mês para o retiro de um dia. Nesse dia, meditam 7 horas e o propósito é reascender a disciplina de praticar a meditação continuamente. No curso de Vipassana, aprendemos que a continuidade da prática é o segredo do sucesso (Melhoria Contínua). A prática de Vipassana está fortemente ligada à ideia de mudança. Praticar Vipassana ajuda cada pessoa a entender profundamente como os processos de mudança acontecem na natureza humana e ensina a lidar de forma objetiva com essas mudanças.

O título em inglês do livro de Padrões para Introduzir Novas Ideias é "Fearless Change" (Mudança sem Medo). Toda inovação, toda ideia nova significa uma mudança. Morre o velho, nasce o novo. A inovação é um processo de transformação. Para introduzir uma nova ideia é preciso convencer a grande massa a mudar, a aceitar a morte do que não é mais adequado ao novo tempo. A própria aceitação da nova ideia causa transformação. Essa transformação cria mais mudança e outras novas ideias. É como um fluxo contínuo e incessante de mudanças. Podemos chamar esse fluxo de vida. Todos nós estamos imersos nesse fluxo. Um grande entrave para a criatividade é o medo da morte, medo da mudança.

O subtítulo do livro do Kent Beck sobre XP: "Embrace Change" (Abrace a Mudança). O quarto preceito do manifesto ágil lembra a importância de adaptar-se a mudanças. Bons projetos de software são aqueles que conseguem implantar melhoria contínua no seu processo de desenvol-

vimento. É mais fácil estabelecer um processo de melhoria contínua quando se tem baixo custo de mudança. Uma das forças que aumenta o custo de mudança é a força de resistência, o medo.

Desta forma, meditação, Arte, padrões e Métodos Ágeis estão fortemente ligados. São pontos de vistas diversos sobre a mesma coisa: mudança e criação. Um outro ponto em comum é que os três falam de práticas. Não se aprende Vipassana falando sobre ela. É preciso praticar. Quem 
não pratica meditação ou quem não exerce alguma atividade artística não é capaz de perceber os benefícios destas. Da mesma forma, não se aprende XP discutindo e racionalizando seus conceitos. XP é trabalho, é dia-a-dia, é melhoria contínua. Uma ideia inovadora não é nada se só existe na cabeça de seu criador. É preciso prática. Padrões são práticas. É preciso viver a experiência para aprender a lidar com as situações inusitadas e "criar" novos padrões (padrões na verdade não são criados, eles já existem, porém precisam ser identificados e nomeados).

Insistimos no aspecto prático da Arte e da meditação porque os efeitos dessas atividades são percebidos em grande parte no nível individual. Apenas o meditador conhece as sensações que ele experimenta, são sensações apenas dele. Quando um artista cria uma obra, ele está exprimindo um sentimento próprio. Qualquer sentimento que esta obra vier a despertar em outras pessoas não é o mesmo do que o artista teve como inspiração para si. Um pintor poderia criar um quadro com uma imagem de um menino sorrindo. O seu sentimento pode ser, por exemplo, o de querer expressar sua alegria ao lembrar do próprio filho. Suponhamos então que uma outra pessoa, cujo filho infante tenha acabado de falecer, venha a observar essa pintura. A imagem da criança sorrindo fará essa pessoa lembrar do próprio filho morto e lhe trará muita tristeza.

A Meditação trabalha a nossa relação com mudanças numa esfera mais profunda e subjetiva. Promove sabedoria de dentro para fora. XP e Padrões para Introduzir Novas Ideias lidam com questões mais superficiais e promovem sabedoria de fora para dentro. E sabedoria é entender como ocorrem as mudanças, por que elas ocorrem e principalmente, como lidar com elas.

Os paradigmas de programação usados hoje são praticamente os mesmos desde o início da década de 80. A maior parte da arquitetura de computadores de hoje é projetada para otimizar os programas de Fortran e $\mathrm{C}$ de décadas atrás. Ainda hoje se faz muito software usando o método Big Design Up Front (BDUF), onde todo o software deve ser pensado e detalhadamente documentado antes de ser codificado em alguma linguagem. Esse tipo de "plano mestre" reflete um desejo de ordem, que nasce do nosso medo de falhar, nosso medo da morte. Temos que encontrar uma maneira de lutar contra o nosso medo da morte. Hoje a realidade da Computação deve se basear exatamente no oposto de planos mestres: tudo muda, se transforma, o que acontece o tempo todo é evolução [GG00]. 


\subsection{Pesquisa de interesses artísticos}

O padrão Faça Arte ${ }^{12}$ só faz sentido se as pessoas da área de tecnologia tiverem algum tipo de interesse por atividades artísticas. Talvez algumas pessoas acreditem que alunos e profissionais de exatas são fechados e se interessam apenas por disciplinas matemáticas e lógicas. Para mostrar que isso é um mito, fizemos duas pesquisas. A primeira delas foi feita numa grande empresa brasileira de serviços de Internet. A outra foi realizada num evento de Métodos Ágeis, em São Paulo. Seguem os resultados obtidos.

\subsubsection{Pesquisa com colaboradores de uma empresa de tecnologia}

Realizamos uma pesquisa dentro de uma empresa de serviços de Internet sobre um possível interesse em atividades artísticas por parte das pessoas da área de tecnologia. A pesquisa foi feita num contexto bem específico. A maioria dos participantes era de engenheiros ou formados em Ciência da Computação, pessoas que tiveram formação tipicamente exata. O objetivo era avaliar se esse grupo de pessoas tinha interesse em desenvolver outras habilidades que não as relacionadas com Computação e sim relacionadas a atividades artísticas. Na pesquisa também comparamos o interesse das pessoas com a prática efetiva dessas atividades.

Pudemos observar que grande parte do grupo possui sim interesse por essas atividades. Porém o interesse é maior do que o conhecimento efetivo, o que indica uma possível dificuldade que essas pessoas têm em seu dia-a-dia ou no seu ambiente de trabalho em concretizar seus interesses por Arte.

O resultado da pesquisa pode ser visto na Figura 4.14. Pedimos para as pessoas preencherem a lista para cada modalidade artística conforme a legenda da Figura 4.13. Cada pessoa preencheu, então, para cada atividade artística, qual o seu interesse em aprender (1a. carinha) e qual a sua prática atual com a atividade (2a. carinha). A partir desse preenchimento, extraímos os dados da Tabela 4.2, onde os graus foram convertidos numa escala de 0 (nenhum interesse / nenhuma experiência) a 3 (muito interesse / muita experiência). Cada linha na Tabela 4.2 representa uma pessoa.

Na média geral, $57 \%$ das pessoas se interessa por aprender e desenvolver atividades artísticas. Apenas $24 \%$ já possui algum conhecimento nessas áreas. Música é a atividade com o maior interesse (95\%) e também com o maior grau de conhecimento (64\%), embora o conhecimento seja bem menor do que o interesse.

\footnotetext{
${ }^{12}$ Vide Seção 3.4.
} 


\begin{tabular}{|c|c|}
\hline Interesse em aprender & Experiência Atual \\
\hline (4) - nenhum & 3 - nenhuma \\
\hline (1) - pouco & (i) - pouca \\
\hline (1) - médio & (1) - média \\
\hline$\Theta$ - muito & $\Theta$ - muita \\
\hline
\end{tabular}

Figura 4.13: Pesquisa sobre interesses artísticos: legenda

\begin{tabular}{|c|c|c|c|c|c|c|c|c|c|c|c|c|c|c|c|c|}
\hline & \multicolumn{2}{|c|}{ Teatro } & \multicolumn{2}{|c|}{ Dança } & \multicolumn{2}{|c|}{ Música } & \multicolumn{2}{|c|}{ Poesia } & \multicolumn{2}{|c|}{ Desenho } & \multicolumn{2}{|c|}{ Pintura } & \multicolumn{2}{|c|}{ Meditação } & Média & Média \\
\hline & I & $\mathrm{E}$ & I & $\mathrm{E}$ & I & $\mathrm{E}$ & I & $\mathrm{E}$ & I & $\mathrm{E}$ & I & $\mathrm{E}$ & I & $\mathrm{E}$ & I & $\mathrm{E}$ \\
\hline Média & 1,67 & 0,64 & 1,50 & 0,67 & 2,64 & 1,89 & 1,00 & 0,53 & 1,89 & 0,67 & 1,36 & 0,53 & 1,69 & 0,69 & 1,68 & 0,80 \\
\hline$\% 2$ ou 3 & $56 \%$ & $14 \%$ & $53 \%$ & $14 \%$ & $94 \%$ & $64 \%$ & $33 \%$ & $17 \%$ & $61 \%$ & $19 \%$ & $39 \%$ & $17 \%$ & $61 \%$ & $22 \%$ & $57 \%$ & $24 \%$ \\
\hline Potencial & $42 \%$ & & $39 \%$ & & $30 \%$ & & $16 \%$ & & $42 \%$ & & $22 \%$ & & $39 \%$ & & $33 \%$ & \\
\hline
\end{tabular}

Tabela 4.2: Dados da pesquisa de interesses artísticos

As pessoas demonstraram bastante interesse por desenho (61\%) e meditação (61\%). Estas foram, junto com teatro e dança as modalidades que apresentaram o maior potencial de desenvolvimento (diferença entre o interesse e a experiência). O potencial de desenvolvimento é de $42 \%$ para o teatro e o desenho e $39 \%$ para dança e a meditação.

A diferença entre o interesse em alguma atividade e a prática real dessa atividade pode ser considerada um potencial de desenvolvimento de uma habilidade artística.

Vale ressaltar que os critérios de avaliação da pesquisa são extremamente subjetivos. Quando falamos de interesse não deixamos (propositadamente) claro o que é esse interesse. Quando falamos em experiência também não queremos avaliar a real experiência que cada pessoa tem com relação a cada modalidade artística. Cada pessoa respondeu à pesquisa conforme suas próprias interpretações do que é cada um dos termos. Mas a conclusão é a mesma: grande parte das pessoas não possui desenvolvidas suas habilidades artísticas e essa falta de desenvolvimento não está relacionada com falta de interesse. 


\begin{tabular}{|c|c|c|c|c|c|c|c|c|}
\hline Cargo & Teatro & Dança & Música & Poesia & Desenho & Pintura & Meditação & Outros... \\
\hline Arquiteto & ()ㅜ & ()ㅜ)(11) & (ㅇ) & 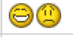 & (으 & (:)(:) & ():-()- & \\
\hline Estagiario & (1) (1) & (1) (1) & ():-1) & (:):-) & 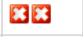 & X & (:):-(:) & \\
\hline Analista Sist. & () (11) & 0 & () -() & (:): $\mathbf{x}$ & $x$ & $\mathbf{x}$ & ()ㅇ (1) & (1) [ - Escrita \\
\hline Analista Sist. & ()ㅜ)(1) & (:)(1) (1) & ():-() & (i): & (키 & (1) $\mathbb{x}$ & (:) & \\
\hline Analista Sist. & (1):-) & (1) (1) & (-) - & (12) (1) & $x$ & $x$ & (11) (1) & \\
\hline Webdesigner & ax & $\mathbb{X}$ & (ㅇ) (1) & x & ()ㅇㅇ & ()ㅇ & ()ㅇ & ()ㅜ (11) - Escultura \\
\hline Analista Sist. & (). (1) & () (1) & () (1) & (:) $\mathbf{x}$ & 잊 & $\Theta \mathbb{x}$ & 이 & \\
\hline Analista Sist. & ().11) & (1) $\boldsymbol{x}$ & $\Theta \ominus$ & (1)(1) & (1) $\boldsymbol{x}$ & (1) & 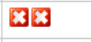 & (:):- - Escrita (contos) \\
\hline Eng. Tecnologia & $\mathbb{x}$ & $\mathbb{x}$ & $\ominus \ominus$ & {$[x$} & $x$ & $x$ & 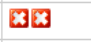 & \\
\hline Analista Tecnologia & a & X & (:)(:) & (1):-) & (1) $\boldsymbol{x}$ & 밈 & $\ominus \ominus$ & \\
\hline Analista Usabilidade & $\theta \theta$ & (:) $\boldsymbol{x}$ & () (-) & $x$ & $\ominus \boldsymbol{x}$ & $\ominus[\mathbf{x}$ & ()ㅣ밍 & \\
\hline Eng. Tecnologia & $\theta \otimes$ & ():-) & (:) & (1) (1) & (:)(1) & (1) (1) & 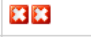 & \\
\hline Eng. Tecnologia & ().11) & ()주 & () (1) & (1) $\boldsymbol{x}$ & (): & (1) & $\mathrm{B}$ & \\
\hline Analista Sist. & () (1) & (11) $\mathbb{x}$ & () (1) & 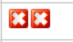 & (:) (1) & () (-) & (:) :-) & \\
\hline Gerente & () & (1): & () & () (-) & $\ominus x$ & $\theta$ & (1): & () $\mathbf{X}$-Regência \\
\hline Estagiário & (-): & (:) $\mathbb{x}$ & ()ㅇㅇ & (1) & (1) & 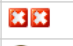 & (-): & \\
\hline Estagiário & (1)(1) & ()ㅜ (1) & (): & (:) $\boldsymbol{x}$ & () (11) & $\ominus \mathbf{x}$ & (:): & \\
\hline Sub-Gerente & $\mathbf{a}$ & $\mathbf{x}$ & $\mathbb{a x}$ & x & (1) $\odot$ & (1) $)$ & $\theta$ & () (1) - Outro idioma \\
\hline Analista Tecnologia & ():- & (1) (1) & ():-() & (ㅇ) & (-):- & (1)(1) & (:):) & () (1) - Trabalhos com Fibra de vidro. \\
\hline Eng. Tecnologia & $\theta \sqrt{x}$ & (-):-) & ()지 & (:) $\mathbf{x}$ & (이 & (:) & 이 & \\
\hline Analista de Sist. Trainne & a & $\mathbb{x}$ & (:): $)$ & (1) & (11) $\odot$ & {$[x$} & (:):) & (:):) djing \\
\hline Gerente de Projetos & $\mathbb{x}$ & $\mathbf{x}: \mathbf{z}$ & $\Theta \ominus$ & {$[\mathbf{x}$} & $\ominus x$ & (1): & (1) $\mathbf{x}$ & \\
\hline Eng. Tecnologia & (1): $x$ & (:) & ():-() & (1): & (:)(1) & (12)(1) & ()ㅈ & \\
\hline Sub-Gerente & (12) (1) & (:) (1) & ()ㅏ (1) & (1) & (ㅇ) (:) & ()ㅏ (1) & (:)(1) & \\
\hline Eng. Tecnologia & xax & $x$ & (:) $)$ & $x$ & (12) (1) & X & Ba & \\
\hline Analista Tecnologia & (1) & (1)(1) & () (1) & (:) (:) & (:)(1) & $\ominus \mathbb{x}$ & $\ominus \ominus$ & \\
\hline Analista Tecnologia & (:):-) & () (1) & (:) $)$ & (1) & (1) $\boldsymbol{x}$ & $\ominus \sqrt{\boldsymbol{x}}$ & $\mathbb{8}$ & \\
\hline Analista Tecnologia & ():-() & 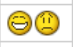 & () (1) & {$[x$} & () (11) & ():) & 요 & $(-)$ - bijuteria / $(-)(-)$ - bordados \\
\hline Analista Tecnologia & () (1) & () & (1) (1) & (1) (11) & (1) & (1) $\mathbf{x}$ & $\mathbb{x}$ & \\
\hline Designer & 8 & $\mathbb{8}$ & $\ominus \ominus$ & $x$ & $\ominus \boldsymbol{x}$ & 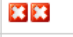 & 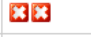 & \\
\hline Analista de Tecnologia & (1)(1) & (:):-) & ()ㅇㅇ & 正 & 이 & (1) $x$ & (1) $x$ & (-) DJing/Produção Musical \\
\hline Gerente de Produtor & Q & $\mathbf{x}$ & $(-)$ & 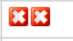 & (:) & 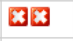 & $\mathbb{8}$ & \\
\hline Analista de Produtos & $\mathbb{8}$ & a: & $\ominus \ominus$ & Ba & {$[\mathrm{B}$} & $\mathbb{a x}$ & {$[\mathbf{x}$} & \\
\hline Arquiteta da Informação & $\theta x$ & () (11) & $\ominus \ominus$ & (:)(:) & (1) & (1) & () (1) & Roteiros e vídeos \\
\hline Analista de Tecnologia & 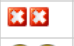 & $\mathrm{Xz}$ & ():-() & 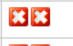 & $\mathrm{XB}$ & 跑 & $\mathrm{B}$ & () (-)- Cinema $(-)(-)$ - Esportes \\
\hline Analista Tecnologia & (1):11) & ()ㅇ & 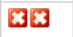 & B & (-):-) & ():-() & ()ㅜ(1) & (-) (-) - Esportes \\
\hline
\end{tabular}

Figura 4.14: Pesquisa sobre interesses artísticos: resultados 


\subsubsection{Pesquisa em um evento de Métodos Ágeis}

Fizemos uma outra pesquisa durante o evento "Encontro Ágil" [Agi08], realizado em setembro de 2008 no IME-USP. O evento era gratuito e tinha por objetivo disseminar práticas ágeis de desenvolvimento de software. Compareceram cerca de 180 pessoas, entre alunos de cursos de Engenharia e Computação, e profissionais da área de desenvolvimento de software. Desse público, 93 responderam a um questionário com dez perguntas, feito através de formulários a serem preenchidos durante o evento. Nós estamos interessados apenas em parte do questionário e, por isso, vamos omitir as perguntas que não são relevantes para nossa pesquisa. Focaremos apenas nas seguintes perguntas:

- Você pratica atualmente alguma dessas atividades? (Escolha até 3 opções entre Teatro, Dança, Música, Poesia, Desenho, Pintura, Meditação, Escultura)

- Quais dessas atividades você teria interesse em aprender? (Escolha até 3 opções entre Teatro, Dança, Música, Poesia, Desenho, Pintura, Meditação, Escultura)

Apesar do interesse de $89 \%$ (ver Tabelas 4.3 e 4.4) das pessoas por pelo menos uma das atividades, observamos que apenas $41 \%$ já estavam praticando alguma delas, ou seja, temos um potencial $^{13}$ de $48 \%$ de crescimento em práticas artísticas dentre pessoas desse público. A atividade mais apreciada é a música, com $26 \%$ de prática e $43 \%$ de interesse. Depois vem a dança $(10 \%$ prática e $31 \%$ de interesse) e a meditação ( $9 \%$ de prática e $25 \%$ de interesse). As atividades com maior potencial de crescimento são teatro e dança, com $22 \%$ de potencial de crescimento na prática.

\begin{tabular}{|l|r|r|r|r|r|r|r|r|r|}
\hline & \multicolumn{10}{|c|}{ Prática Atual } \\
\hline & Meditação & Teatro & Música & Pintura & Desenho & Escultura & Poesia & Dança & Alguma* \\
\hline Técnicos & 3 & 2 & 18 & 1 & 4 & 0 & 2 & 7 & 26 \\
$\%$ & $5 \%$ & $3 \%$ & $27 \%$ & $2 \%$ & $6 \%$ & $0 \%$ & $3 \%$ & $11 \%$ & $39 \%$ \\
\hline Gerentes & 5 & 1 & 6 & 1 & 3 & 0 & 0 & 2 & 12 \\
$\%$ & $19 \%$ & $4 \%$ & $22 \%$ & $4 \%$ & $11 \%$ & $0 \%$ & $0 \%$ & $7 \%$ & $44 \%$ \\
\hline Total & 8 & 3 & 24 & 2 & 7 & 0 & 2 & 9 & 38 \\
$\%$ & $9 \%$ & $3 \%$ & $26 \%$ & $2 \%$ & $8 \%$ & $0 \%$ & $26 \%$ & $10 \%$ & $41 \%$ \\
\hline * quando há interesse em pelo menos uma das atividades anteriores
\end{tabular}

Tabela 4.3: Pesquisa sobre a prática de atividades artísticos durante o Encontro Ágil 2008

\begin{tabular}{|l|r|r|r|r|r|r|r|r|r|}
\hline & \multicolumn{10}{|c|}{ Interesse Futuro } \\
\hline & Meditação & Teatro & Música & Pintura & Desenho & Escultura & Poesia & Dança & Alguma* \\
\hline Técnicos & 15 & 19 & 30 & 14 & 17 & 6 & 5 & 20 & 60 \\
$\%$ & $23 \%$ & $29 \%$ & $45 \%$ & $21 \%$ & $26 \%$ & $9 \%$ & $8 \%$ & $30 \%$ & $91 \%$ \\
Potencial & $18 \%$ & $26 \%$ & $18 \%$ & $20 \%$ & $20 \%$ & $9 \%$ & $5 \%$ & $20 \%$ & $52 \%$ \\
\hline Gerentes & 8 & 4 & 10 & 4 & 8 & 4 & 1 & 9 & 23 \\
\hline
\end{tabular}

\footnotetext{
${ }^{13} \mathrm{O}$ potencial é calculado pela diferença entre interesse em aprender e prática atual
} 


\begin{tabular}{|l|r|r|r|r|r|r|r|r|r|}
\hline & \multicolumn{10}{|c|}{ Interesse Futuro } \\
\hline & Meditação & Teatro & Música & Pintura & Desenho & Escultura & Poesia & Dança & Alguma* \\
\hline$\%$ & $30 \%$ & $15 \%$ & $37 \%$ & $15 \%$ & $30 \%$ & $15 \%$ & $4 \%$ & $33 \%$ & $85 \%$ \\
Potencial & $11 \%$ & $11 \%$ & $15 \%$ & $11 \%$ & $19 \%$ & $15 \%$ & $4 \%$ & $26 \%$ & $41 \%$ \\
\hline Total & 23 & 23 & 40 & 18 & 25 & 10 & 6 & 29 & 83 \\
$\%$ & $25 \%$ & $25 \%$ & $43 \%$ & $19 \%$ & $27 \%$ & $11 \%$ & $6 \%$ & $31 \%$ & $89 \%$ \\
Potencial & $16 \%$ & $22 \%$ & $17 \%$ & $17 \%$ & $19 \%$ & $11 \%$ & $4 \%$ & $22 \%$ & $48 \%$ \\
\hline
\end{tabular}

Tabela 4.4: Pesquisa sobre interesse futuro em atividades artísticas durante o Encontro Ágil 2008

Extraímos alguns dados, separando as pessoas em dois grupos: técnicos (66 pessoas) e gerentes (27 pessoas). Os técnicos são aqueles que desempenham atividades de programadores, testadores, administradores de rede, administradores de bancos de dados. Os gerentes são líderes de equipes, diretores ou donos de pequenas empresas. Observamos que a prática de atividades artísticas é ligeiramente maior entre os gerentes $(44 \%)$ do que entre os técnicos (39\%), mas que o interesse por alguma atividade é ligeiramente maior entre os técnicos (91\%) do que entre os gerentes (85\%), mostrando que o potencial (não praticam nada, mas tem interesse) dos técnicos é de $52 \%$, contra $41 \%$ para os gerentes.

Entre os gerentes, $19 \%$ praticam meditação, bem acima dos $5 \%$ de prática pelos técnicos, mostrando grande interesse nesse tipo de prática por pesquisados que gerenciam pessoas. Entre os técnicos, a atividades que possui maior potencial é o Teatro (26\%), enquanto que para gerentes é a Dança (26\%). Apesar dos benefícios da poesia para o desenvolvimento de software citados na Seção 4.4, vimos que essa é uma das atividades que desperta menor interesse. Talvez pudéssemos usar padrões para introduzir novas ideias para convencer esse público a ler e/ou escrever poesia no seu cotidiano.

\subsubsection{O uso da Arte na Indústria de Software}

Pudemos perceber, pelas pesquisa que fizemos, que existe um enorme potencial de aprendizado de atividades artísticas por parte de alunos e profissionais da área da Computação. Apesar de existir um razoável interesse por essas artes, sua atividade prática é pouco explorada.

Nesta seção vimos várias alternativas de atividades artísticas. Não pretendemos afirmar que todo aluno ou profissional deva se desenvolver em todas as artes. Supomos que, para eles, a Arte prioritária seja desenvolver software. Essa é a atividade em que trabalharão a maior parte do tempo. Porém, para desenvolver justamente a capacidade de produzir software de qualidade e relevante para a humanidade, propomos que os hackers pratiquem e se estabeleçam em alguma dessas atividades artísticas. Cada pessoa terá um gosto particular por uma ou outra. A união de vários artistas da computação num time de desenvolvimento criativo fará emergir grandes produtos de software. Eles 
terão as habilidades necessárias para idealizar, projetar, desenvolver, testar, implantar e disseminar esse software.

Sem habilidades artísticas, corremos o risco de que algumas boas ideias que passam pelas cabeças dos hackers podem estar sendo perdidas, simplesmente pelo fato de que algumas vezes eles não têm desenvolvidas habilidades para comunicar e convencer as pessoas de suas ideias. 


\section{Conclusões}

Após estudar os padrões para introduzir novas ideias, muitos deles puderam ser postos em prática, trazendo-nos bons resultados, o que é um indício de que eles realmente são padrões. Na tentativa de introduzir Métodos Ágeis numa empresa brasileira, agi como um Evangelista (2.2.1). Apresentando apenas O Suficiente (2.9.3) para pessoas mais próximas e que Adotam Cedo (2.1.2), pude começar a mostrar alguns conceitos sobre o que são Métodos Ágeis. Inicialmente, propus apenas uma Rodada de Testes (2.8.1). Fomos introduzindo Passo a Passo (2.2.5) as práticas da metodologia no dia-a-dia da equipe.

Iniciamos um Grupo de Estudos (2.5.3) que discutia vários assuntos, entre eles a adoção de Metodologias Ágeis. Tinha um Guru do Meu Lado (2.3.2) e sempre que possível pedia a ele uma Revisão (2.8.2) sobre os mais variados assuntos. Ele me ajudou muito a entender a estrutura da empresa e como lidar com os mais resistentes, algumas vezes servindo até como um Ombro para Chorar (2.6.3). Aos poucos pude me aproximar de Conectores (2.3.1) e Construtores de Pontes (2.11.1). Eu pude Pedir Ajuda (2.3.3) a essas pessoas e elas foram essenciais para que as ideias ágeis chegassem aos líderes da corporação. Várias vezes me vi fazendo Política de Corredor (2.11.3).

Uma Grande Personalidade (2.8.3) na área de tecnologia veio à empresa dar uma palestra. Sem que eu esperasse, essa pessoa disse gostar bastante de Métodos Ágeis, citando casos de sucesso de outras corporações internacionais. Essa Validação Externa (2.4.6) deu um impulso enorme às mudanças. Quando essa pessoa veio falar, o evento foi realizado na própria empresa, fugindo do padrão Local, Local, Local (2.9.6). Nos intervalos, as pessoas subiam rapidamente para ler seus emails e tentar resolver algumas pendências. Talvez se esses pequenos momentos fossem evitados, todos teriam aproveitado melhor o conteúdo da palestra. Mas não acredito que isso tenha sido um impedimento para o aprendizado, nesse caso.

Algumas vezes, tivemos a necessidade de tornar o ambiente mais informal, para facilitar a aceitação da ideia. Para isso, usamos os padrões Brinque com Eles (3.1) e Faça Arte (3.4). Não conseguiríamos criar e testar esses padrões, se não tivéssemos Mergulhado Fundo (3.2) e trabalhado arduamente nessa dissertação.

Nossas experiências em atividades artísticas como Teatro (4.1), Música (4.2) e Poesia (4.4) nos 
ajudaram disseminar nossas ideias, uma vez que essas atividades aprimoraram nossa capacidade criativa e de comunicação. O processo de introduzir uma ideia foi demorado e difícil. Para manter a calma, paciência e para poder entender a realidade da mente com clareza, sem perder o objetivo de introduzir nossa ideia, praticamos Meditação (4.5).

Alguns padrões não foram ainda experimentados por nós. Isso não significa que não sejam eficazes, mas talvez apenas que não sejam aplicáveis à nossa realidade. Logo no início da tentativa de mudança, pedimos para usar o Nosso Espaço (2.9.4) para pendurar cartões e cartazes, como a metodologia XP sugere. Esse pedido foi negado de início, porém depois de apresentar melhor as ideias ágeis, um Anjo Corporativo (2.7.3) autorizou o uso do espaço. Hoje o espaço de trabalho é cheio de cartazes e cartões de papel que aumentam a qualidade da comunicação.

A Primeira Maioria (2.1.3) já está usando nossas ideias. Certamente já Plantamos as Sementes (2.4.5) e o primeiro passo já foi dado. Agora é Tempo para Reflexão (2.2.3) para sabermos quais são os Próximos Passos (2.4.7). Provavelmente, além de continuar usando esses padrões, tentarei falar para as pessoas sobre eles. Gostaria de Envolver Todos (2.10.1) nesse trabalho. Daí surge a recorrência: usaremos Padrões para Introduzir Novas Ideias e Arte para tentar mostrar às pessoas que o uso de Padrões para Introduzir Novas Ideias e Arte é benéfico para o desenvolvimento de software. 


\section{Referências Bibliográficas}

[AFdA09] Rafael Evangelista Sergio Amadeu da Silveira Vicente Macedo de Aguiar Anderson Fernandes de Alencar, Murilo Bansi Machado. Software livre, cultura hacker e ecossistema da colaboração. Momento Editorial, São Paulo, Brasil, 2009.

[Agi08] AgilCoop. Encontro Ágil. Disponível em: http://www.encontroagil.com.br, 2008. Acessado em: 04/04/2009.

[AIS ${ }^{+} 77$ Christopher Alexander, Sara Ishikawa, Murray Silverstein, Max Jacobson, Ingrid Fiksdahl-King, and Shlomo Angel. A Pattern Language: Towns, Buildings, Construction. Oxford University Press New York, 1977.

[AM06] Abel Avram and Floyd Marinescu. Domain-Driven Design Quickly. C4Media, 2006.

[AS06] Scott W. Ambler and Pramod J. Sadalage. Refactoring Databases: Evolutionary Database Design. Addison-Wesley, 2006.

[BA04] Kent Beck and Cynthia Andress. Extreme Programming Explained: Embrace Change. Addison-Wesley Professional, 2nd edition, 2004.

[BB06] Ori Brafman and Rod A. Beckstrom. The Starfish and the Spider: The Unstoppable Power of Leaderless Organizations. Portfolio, 2006.

$\left[\mathrm{BBvB}^{+} 01\right]$ Kent Beck, Mike Beedle, Arie van Bennekum, Alistair Cockburn, Ward Cunningham, Martin Fowler, James Grenning, Jim Highsmith, Andrew Hunt, Ron Jeffries, Jon Kern, Brian Marick, Robert C. Martin, Steve Mellor, Ken Schwaber, Jeff Sutherland, and Dave Thomas. Manifesto for agile software development. Disponível em: http: //www.agilemanifesto.org, 2001. Acessado em: 18/03/2008.

[Bec99] Kent Beck. Extreme Programming Explained: Embrace Change. Addison-Wesley Professional, 1999.

[Bec03] Kent Beck. Test-driven development: by example. Addison-Wesley Professional, 2003. 
[BJP59] Walter F. Bauer, Mario L. Juncosa, and Alan J. Perlis. ACM publication policies and plans. Journal of the ACM (JACM), 6(2):121-122, 1959.

[BK08] Paulo Cheque Bernardo and Fabio Kon. A Importância dos Testes Automatizados. Engenharia de Software Magazine, pages 54-57, 1(3) 2008.

[BL76] C. Borland and G. Landrith. Improved quality of city life through the transcendental meditation program: Decreased crime rate. Scientific Research on the Transcendental Meditation Program: Collected Papers (Vol. 1, pp. 639-648). Rheinweiler, W. Germany: Maharishi European Research University Press, 1976.

$\left[\mathrm{BMR}^{+}\right.$96] Frank Buschmann, Regine Meunier, Hans Rohnert, Peter Sommerlad, and Michael Stal. Pattern-Oriented Software Architecture Volume 1: A System of Patterns. John Wiley \& Sons, Inc. New York, NY, USA, 1996.

[Boa98] Augusto Boal. Jogos para Atores e Não Atores. Civilização Brasileira, 1998.

[Bon98] Nilton Bonder. A Alma Imoral - Traição e tradição através dos tempos. Rocco, 1998.

[Bro87] Frederick Phillips Brooks. No Silver Bullet: Essence and Accidents of Software Engineering. IEEE Computer, 20(4):10-19, 1987.

[Bro95] Frederick Phillips Brooks. The Mythical Man-Month: Essays on Software Engineering. Addison-Wesley, 1995.

[Bur08] Ed Burns. Secrets of the Rock Star Programmers: Riding the IT Crest. McGrawHill/Osborne, 2008.

[Che88] David J. Cheal. The Gift Economy. Routledge, 1988.

[Cis05] Thomas Ciszek. A Framework for the Development of Social Linking Theory. 2005.

[Coc04] A. Cockburn. Crystal Clear: a human-powered methodology for small teams. AddisonWesley Professional, 2004.

[Coc06] Alistair Cockburn. Agile Software Development: The Cooperative Game (Agile Software Development Series). Addison-Wesley Professional, 2006.

[Coh04] Mike Cohn. User Stories Applied: For Agile Software Development. Addison-Wesley Professional, 2004.

[Cru01] John Crupi. Core J2EE Patterns. Disponível em: http://java.sun.com/developer/ technicalArticles/J2EE/corepatterns/, 8 2001. Acessado em: 07/03/2009. 
[Cuk09] Daniel Cukier. Para Todos. Scortecci, 2009.

[CVPA95] Kishore Chandiramani, S.K. Verma, P.L.Dhar, and N. Agarwal. Study of the psychological effects of vipassana on tihar jail inmates. All India Institue of Medical Sciences, 1995.

[Dij71] Edsger W. Dijkstra. A Short Introduction to The Art of Programming. Technische Hogeschool Eindhoven, 1971.

[DM00] Domenico De Masi. O Ócio Criativo. Sextante, 2000.

[dS07] Alexandre F. da Silva. Reflexões Sobre o Ensino de Metodologias Ágeis na Academia, na Indústria e no Governo. Master's thesis, IME-USP, Jun 2007.

[Eva04] Eric Evans. Domain-Driven Design: Tackling Complexity in the Heart of Software. Addison-Wesley Professional, 2004.

[Fey07] P. Feyerabend. Contra o Método. Editora Unesp, 2007.

[Fie34] Thomas Fielden. The Science of Pianoforte Technique. Macmillan London, 1934.

[Fow97] Martin Fowler. Analysis Patterns: reusable object models. Addison-Wesley Professional, 1997.

[Fow00] Martin Fowler. Refactoring: Improving the Design of Existing Code. Addison-Wesley, 2000 .

[Fow03] Martin Fowler. Patterns of Enterprise Application Architecture. Addison-Wesley Professional, 2003.

[Gab02] Richard P. Gabriel. Writer's Workshops and the Work of Making Things. AddisonWesley Longman Publishing Co., Inc. Boston, MA, USA, 2002.

[Gab04] Richard P. Gabriel. What is Science? What is Art? Extravagaria 2 - Art Assisting Science - Workshop At OOPSLA 2004. Disponível em: http://www.dreamsongs . com, 2004. Acessado em: 27/10/2008.

[Gab06] Richard P. Gabriel. Design Beyond Human Abilities. http://dreamsongs.com/ Files/DesignBeyondHumanAbilitiesSimp.pdf, 2006. Acessado em: 20/06/2008.

[GC02] Eliyahu M. Goldratt and Jeff Cox. A Meta - Um Processo de Melhoria Contínua. Nobel, 2002. 
[GG00] Richard P. Gabriel and Ron Goldman. Mob software: The erotic life of code. ACM Conference Object Oriented Programming, Systems, Languages, and Applications Keynote Speech, 2000.

[GG05] Richard P. Gabriel and Ron Goldman. Innovation Happens Elsewhere. Morgan Kaufmann, 2005.

[GHJV95] Erich Gamma, Richard Helm, Ralph Johnson, and John Vlissides. Design Patterns: Elements of Reusable Object-Oriented Software. Addison-Wesley, Boston, MA, January 1995.

[Gra04] Paul Graham. Hackers 8 Painters: Big Ideas from the Computer Age. O'Reilly Media, Inc., 2004.

[Har87] William Hart. The Art of Living - Vipassana Meditation As Taught by S.N. Goenka. Harper Collins, 1987.

[Hei02] Janice J. Heiss. The Poetry of Programming - Entrevista com Richard P. Gabriel. http://java.sun.com/features/2002/11/gabriel_qa.html, dez 2002.

[HFR00] Neil Harrison, Brian Foote, and Hanns Rohnert. Pattern Languages of Program Design - Volume 4. Addison-Wesley, 2000.

[HT01] Andrew Hunt and David Thomas. The Art in Computer Programming. The Pragmatic Programmers, LLC, 2001.

[Hum92] J.N. Hummel. The Art of Playing the Piano Forte. Royal College of Music, 1992.

[Hun08] Andy Hunt. Pragmatic Thinking and Learning: Refactor Your Wetware (Pragmatic Programmers). 2008.

[Inc08] VersionOne Inc. 3rd Annual Survey: 2008 - The State of Agile Development. Disponivel em: http://www. versionone. com/agilesurvey/, 2008.

[int09] Refactoring - Intergrade: OO Grid Middleware. Disponível em: http://integrade. incubadora.fapesp.br/portal/maratonas, 2009. Acessado em: 20/03/2009.

[Jem06] Mae Jemison. Mae Jemison on Teaching Arts and Sciences Together. http://www.ted.com/index.php/talks/mae_jemison_on_teaching_arts_and_ sciences_together.html, 2006. 
[Jon07] Rachel Jones. Learning to Pay Attention. Public Library of Science: Biology, page $5(6): 166$, junho 2007.

[Kni07] Henrik Kniberg. Scrum and XP from the Trenches. C4Media, 2007.

[Knu74] Donald E. Knuth. Computer programming as an art. Commun. ACM, 17(12):667-673, 1974.

[Knu97] Donald E. Knuth. The Art of Computer Programming. addison-Wesley, 1997.

[Koc67] George A. Kochevitsky. The Art of Piano Playing: a Scientific Approach. Alfred Publishing, 1967.

[Kru06] Steve Krug. Don't Make me Think - A Common Sense Approach to Web Usability Second Edition. New Riders, 2006.

[Kuh07] Tomas Kuhn. A Estrutura das Revoluções Científicas. Perspectiva, São Paulo, Brasil, 2007.

[LDTD07] Antoine Lutz, John D. Dunne, E. Thompson, and Richard J. Davidson. Meditation and the Neuroscience of Consciousness. Cambridge handbook of consciousness, pages 499-551, 2007.

[Lee02] Ted Leemann. Managing the chaos of change. Journal of Business Strategy, 23(5):1115, 2002.

[LGR ${ }^{+}$04] Antoine Lutz, Lawrence L. Greischar, Nancy B. Rawlings, Matthieu Ricard, and Richard J. Davidson. Long-term Meditators Self-induce High-amplitude Gamma Synchrony During Mental Practice. Proceedings of the National Academy of Sciences of the United States of America, 101:16369-73, 2004.

[Lyn08] David Lynch. Em Águas Profundas. Gryphus, 2008.

[Mar08] Robert C. Martin. Clean Code: A Handbook of Agile Software Craftsmanship (Robert C. Martin Series). Prentice Hall PTR, August 2008.

[McB02] Pete McBreen. Software Craftsmanship: The New Imperative. Addison-Wesley Professional, 2002.

[Mes07] Gerard. Meszaros. XUnit Test Patterns: Refactoring Test Code. Addison-Wesley, 2007. 
[MRB97] Robert C. Martin, Dirk Riehle, and Frank Buschmann. Pattern Languages of Program Design - Volume 3. Addison-Wesley Longman Publishing Co., Inc. Boston, MA, USA, 1997.

[MVN06] Dragos Manolescu, Markus Voelter, and James Noble. Pattern Languages of Program Design 5. Addison-Wesley, 2006.

[NFG ${ }^{+}$06] Linda Northrop, Peter Feiler, Richard P. Gabriel, John Goodenough, Rick Linger, Tom Longstaff, Rick Kazman, Mark Klein, Douglas Schmidth, Kevin Sullivan, and Kurt Wallnau. Ultra-large-scale Systems: The Software Challenge of the Future. Software Engineering Institute, Carnegie Mellon University, Pittsburg, PA, 2006.

[NL93] Heinrich Neuhaus and K.A. Leibovitch. The Art of Piano Playing. Kahn \& Averill London, 1993.

[OM98] Yoshi Oida and Lorna Marshall. The Invisible Actor. Routledge, 1998.

[OW07] Andy Oram and Greg Wilson. Beautiful Code: Leading Programmers Explain how They Think. O'Reilly, 2007.

[Pes05] Fernando Pessoa. Poesia Completa de Alberto Caeiro. Companhia das Letras, SP, Brasil, 2005.

[pic46] Pablo Picasso - Bull: A Master Class on Abstract Art. Disponível em: http://www.artyfactory.com/art_appreciation/animals_in_art/pablo_ picasso/pablo_picasso.htm, 1946. Acessado em: 16/08/2008.

[Pin97] Claudio S. Pinhanez. Computer Theater. In Proc. of the Eighth International Symposium on Electronic Arts (ISEA'97), Chicago, Illinois, Setembro 1997.

[Pin07] Claudio Pinhanez. A Services Theory Approach to Online Service Applications. Services Computing, IEEE International Conference on, 0:395-402, 2007.

[plo94] Pattern Languages of Programs http://st-www.cs.uiuc.edu/ plop/, 1994.

[PP03] Mary Poppendieck and Tom Poppendieck. Lean Software Development: An Agile Toolkit. Addison Wesley, 2003.

[RM05] Linda Rising and Mary Lynn Manns. Fearless Change: Patterns For Introducing New Ideas. Addison-Wesley, Boston, 2005.

[Rog95] E.M. Rogers. Diffusion of Innovations. Free Press, 1995. 
[Roy70] W.W. Royce. Managing the development of large software systems. In Proceedings of IEEE Wescon, volume 26, page 9, 1970.

[San02] Yeda S. Santos. Teatro na Matemática e na História. Jornal da USP, (588):1, abril 2002 .

[SCB08] Danilo T. Sato, Huho Corbucci, and Mariana V. Bravo. Coding Dojo: An Environment for Learning and Sharing Agile Practices. In Agile, 2008. AGILE'08. Conference, pages 459-464, 2008.

[Set97] Valdemar W. Setzer. O Computador como Instrumento de Anti-Arte. Anais do VIII Simpósio Brasileiro de Informática na Educação, São José dos Campos, pages 509530, nov 1997.

[Set02] Valdemar W. Setzer. IA - Inteligência Artificial ou Imbecilidade Automática? As máquinas podem pensar e sentir? http://www.ime.usp.br/ vwsetzer/AI.html, 2002. Acessado em: 22/02/2009.

[Set06a] Valdemar W. Setzer. Um Antídoto Contra o Pensamento Computacional. http: //www.ime.usp.br/ vwsetzer/antidoto.html, 2006.

[Set06b] Valdemar W. Setzer. Uma Introdução Antroposófica à Constituição Humana. http: //www.sab.org.br/antrop/const2.htm, Versão 3.1 2006. Seção 4.1.

[SL90] Amadeo Sole-Leris. Tranquillity and Insight. Buddhist Publication Society, 1990.

[SMWW02] Giancarlo Succi, Michele Marchesi, Laurie Williams, and James Donovan Wells. Extreme Programming Perspectives. Addison-Wesley, Boston, MA, USA, 2002.

[Sob07] Stanley Sobottka. A Course in Consciousness. Disponível em: http://www.faculty . virginia.edu/consciousness/, 2007. Acessado em: 16/08/2008.

[Sta06] Constantin Stanislavski. A preparação do Ator. Civilização Brasileira, 2006.

[VCK96] John M. Vlissides, James O. Coplien, and Norman L. Kerth. Pattern Languages of Program Design - Volume 2. Addison-Wesley Longman Publishing Co., Inc. Boston, MA, USA, 1996.

[vri] Vipassana Reseach Institute - research papers. Disponível em: http://www.vri. dhamma.org/publications/research.html. Acessado em: 27/09/2008. 
[WeS98] W. Weiszflog and A.P. e Silva. Michaelis: Moderno Dicionário da língua portuguesa. Melhoramentos, 1998.

[Win71] Donald W. Winnicott. O Brincar \& a Realidade. Imago Editora, 1971.

[WK02] Laurie Williams and Robert Kessler. Pair Programming Illuminated. Addison-Wesley Professional, 2002.

[WL07] Laurie Williams and Lucas Layman. Lab Partners: If They're Good Enough for the Sciences, Why Aren't They Good Enough for Us? Conference on Software Engineering Education and Training (CSEEET 'O7), 2007.

[Yog63] Maharishi Mahesh Yogi. The Science of Being and Art of Living. Allied Publishers, 1963.

[Zha08] Liping Zhao. Patterns, Symmetry, and Symmetry Breaking. Communications of The ACM, 51(3):40-46, Março 2008. 